Prepared in cooperation with the Town of North Hempstead and the New York State Department of Environmental Conservation

\title{
Simulation of Groundwater Flow Pathlines and Freshwater/ Saltwater Transition Zone Movement, Manhasset Neck, Nassau County, New York
}

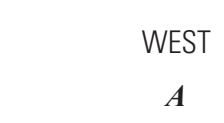

Manhasset Bay

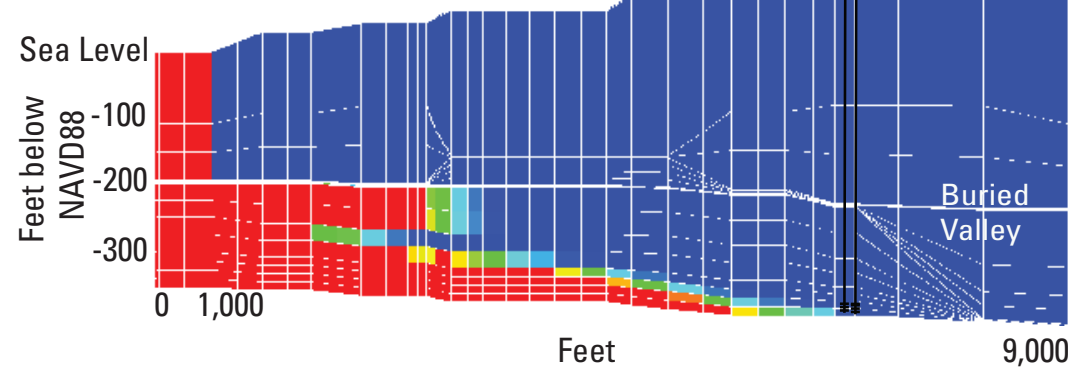

EXPLANATION

Simulated chloride concentration, $\mathrm{mg} / \mathrm{L}$

250 (MCL)

2007

125

Scientific Investigations Report 2013-5201

Version 1.1, June 2014

U.S. Department of the Interior

U.S. Geological Survey 
Front cover. Section of 2007 conditions simulated chloride concentration (see report figure 16B). 


\section{Simulation of Groundwater Flow Pathlines and Freshwater/Saltwater Transition Zone Movement, Manhasset Neck, Nassau County, New York}

By Paul Misut and Omkar Aphale

Prepared in cooperation with the Town of North Hempstead and the

New York State Department of Environmental Conservation

Scientific Investigations Report 2013-5201

Version 1.1, June 2014 


\title{
U.S. Department of the Interior SALLY JEWELL, Secretary
}

\section{U.S. Geological Survey Suzette M. Kimball, Acting Director}

\author{
U.S. Geological Survey, Reston, Virginia \\ First release: 2014 \\ Revised: June 2014 (ver 1.1)
}

\begin{abstract}
For more information on the USGS - the Federal source for science about the Earth, its natural and living resources, natural hazards, and the environment, visit http://www.usgs.gov or call 1-888-ASK-USGS.

For an overview of USGS information products, including maps, imagery, and publications, visit http://www.usgs.gov/pubprod
\end{abstract}

To order this and other USGS information products, visit http://store.usgs.gov

Any use of trade, firm, or product names is for descriptive purposes only and does not imply endorsement by the U.S. Government.

Although this information product, for the most part, is in the public domain, it also may contain copyrighted materials

as noted in the text. Permission to reproduce copyrighted items must be secured from the copyright owner. Suggested citation:

Misut, Paul, and Aphale, Omkar, 2014, Simulation of groundwater flow pathlines and freshwater/saltwater transition zone movement, Manhasset Neck, Nassau County, New York (ver. 1.1, June 2014): U.S. Geological Survey Scientific Investigations Report 2013-5201, 44 p., http://dx.doi.org/10.3133/sir20135201.

ISSN 2328-0328 (online) 


\section{Acknowledgments}

The authors wish to thank Assemblyman Thomas DiNapoli and the Residents for a More Beautiful Port Washington who helped secure funding for this study; the Nassau County Department of Public Works for providing access to historical data from their observation well network; and the New York State Department of Environmental Conservation at Stony Brook, N.Y., for maintaining and providing production-well pumpage data. 
This page has been left blank intentionally. 


\section{Contents}

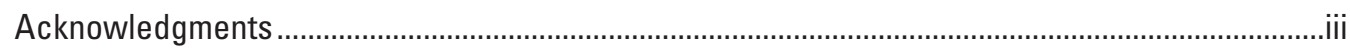

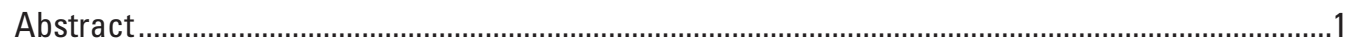

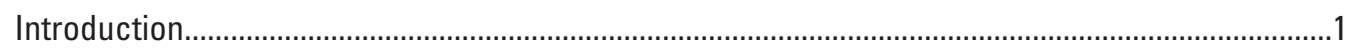

Purpose and Scope ......................................................................................................

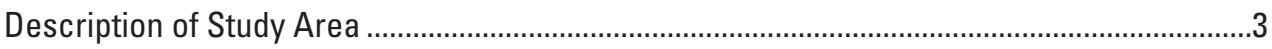

Groundwater-Flow System......................................................................................................

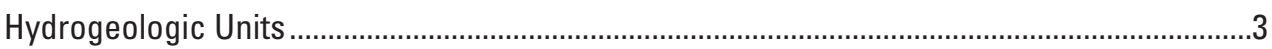

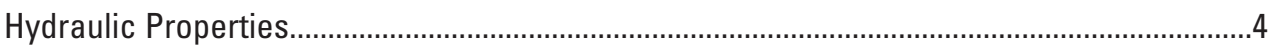

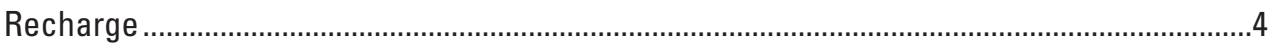

Discharge and Pumping …………………………………...........................................

Groundwater-Flow Directions ...........................................................................................

Freshwater/Saltwater Transition Zone................................................................................10

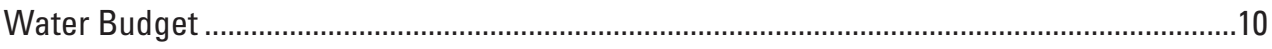

Simulation of Groundwater Pathlines and Freshwater/Saltwater Transition Zone Movement......15

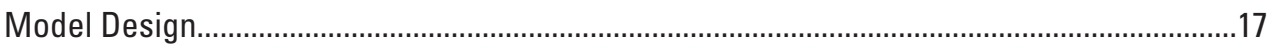

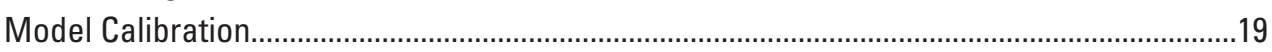

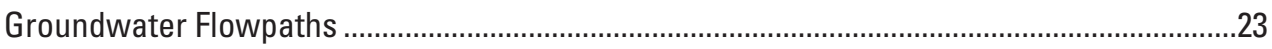

Freshwater/Saltwater Transition Zone Movement ............................................................32

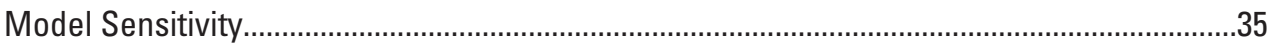

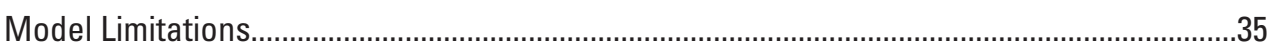

Summary and Conclusions .........................................................................................................

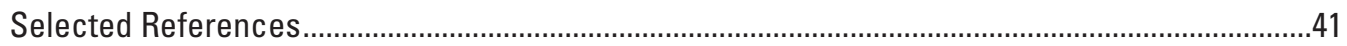

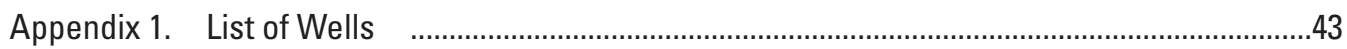

Appendix 2. Slice-sequence animations of hydrogeologic units, Manhasset Neck

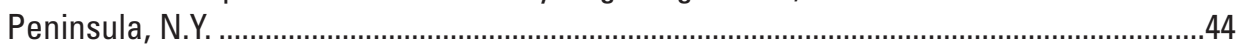

\section{Figures}

1. Map showing location of the study area Manhasset Neck, Nassau County, New York, with the SEAWAT model grid

2. Map showing location of the wetlands and impervious areas, Manhasset Neck, New York

3. Map showing location of US. Geological Survey streamgages, wetlands, and depth of shallow water, Manhasset Neck, New York.

4. Map showing annual pumpage rates of production wells on and near Manhasset Neck, New York, 2006.

5. Schematic section showing groundwater flow patterns, Manhasset Neck, New York

6. Geophysical logs of observation wells A, N12793, B, N12508, and C, N12318 showing salinity (chloride concentration) change, Manhasset Neck, New York, 1994-2008 .......11

7. Map showing location of water-budget components of a SUTRA finite-element model, Manhasset Neck, New York ............................................................................

8. Map showing model boundary conditions, Manhasset Neck, New York .........................16 
9. Graph showing estimated recharge and well N1715 pumpage, Manhasset Neck, New York, 1920-2030.

10. Graph showing water levels in observation wells at model boundaries, Manhasset Neck, New York......

11. Maps showing vertical hydraulic conductivity and simulated water-level contours in the $A$, upper glacial aquifer, B, Magothy aquifer, and C, North Shore/Lloyd aquifers Manhasset Neck, New York, 2007.

12. Map showing simulated saline-groundwater contours in Lloyd and North Shore aquifers, Manhasset Neck, New York, 1920-2007

13. Hydrographs showing simulated and observed water levels in selected wells, Manhasset Neck, New York, 1930-2030

14. Maps showing simulated particle pathlines from the water table or deep sources to selected production wells in A, Christopher Morley Park and Roslyn Estates, B, Lake Success and North New Hyde Park, C, Strathmore and Flower Hill, D, Port Washington, and E, Baxter Estates, Round Hill/Tibbets Lane, Governors Lane, Village Club, and, Sands Point Golf Club, Manhasset Neck, New York, 2007

15. Map showing simulated particle pathlines from forward tracking of particles introduced at the water table during present steady-state conditions, Manhasset Neck, New York

16A. Map showing lines of the simulated freshwater/saltwater transition zone in the Lloyd and North Shore aquifers for three scenarios, Manhasset Neck, New York, 2007-2030

16B. Graphs showing lines of the simulated freshwater/saltwater transition zone in the Lloyd and North Shore aquifers for three scenarios, Manhasset Neck, New York, 2007-2030

17. Hydrographs of measured and simulated salinity (chloride concentration) from three scenarios at selected wells, Manhasset Neck, New York, 1920-2030.

18. Graph showing sensitivity of simulated salinity (chloride concentration) to changes in the vertical and horizontal hydraulic conductivity in the Lloyd and North Shore aquifers at observation well N12508, Manhasset Neck, New York, 1920-2030, using the SEAWAT model

\section{Tables}

1. Characteristics of hydrogeologic units, Manhasset Neck, New York.

2. Groundwater budgets for three periods from the SUTRA model, Manhasset Neck, New York

3. Water budgets for three periods from the SEAWAT model, Manhasset Neck, New York

4. Calibration statistics for water levels from the SEAWAT and SUTRA models for Manhasset Neck, New York

5. Horizontal and vertical hydraulic conductivity of aquifers and confining units simulated using the SEAWAT and SUTRA models of Manhasset Neck, New York 


\section{Conversion Factors and Datum}

\begin{tabular}{|c|c|c|}
\hline Multiply & By & To obtain \\
\hline \multicolumn{3}{|c|}{ Length } \\
\hline inch (in.) & 2.54 & centimeter $(\mathrm{cm})$ \\
\hline foot $(\mathrm{ft})$ & 0.3048 & meter (m) \\
\hline \multicolumn{3}{|c|}{ Area } \\
\hline square mile $\left(\mathrm{mi}^{2}\right)$ & 2.590 & square kilometer $\left(\mathrm{km}^{2}\right)$ \\
\hline \multicolumn{3}{|c|}{ Volume } \\
\hline million gallons (Mgal) & 3,785 & cubic meter $\left(\mathrm{m}^{3}\right)$ \\
\hline \multicolumn{3}{|c|}{ Flow rate } \\
\hline cubic foot per second $\left(\mathrm{ft}^{3} / \mathrm{s}\right)$ & 0.02832 & cubic meter per second $\left(\mathrm{m}^{3} / \mathrm{s}\right)$ \\
\hline inch per year (in/yr) & 25.4 & millimeter per year (mm/yr) \\
\hline million gallons per day (Mgal/d) & 0.04381 & cubic meter per second $\left(\mathrm{m}^{3} / \mathrm{s}\right)$ \\
\hline \multicolumn{3}{|c|}{ Mass } \\
\hline pound, avoirdupois (lb) & 0.4536 & kilogram (kg) \\
\hline \multicolumn{3}{|c|}{ Hydraulic conductivity } \\
\hline foot per day (ft/d) & 0.3048 & meter per day $(\mathrm{m} / \mathrm{d})$ \\
\hline \multicolumn{3}{|c|}{ Salinity } \\
\hline chloride, $\mathrm{mg} / \mathrm{L}$ & 0.0018066 & Salinity, parts per thousand \\
\hline \multicolumn{3}{|c|}{ Density } \\
\hline pound per cubic foot $\left(\mathrm{lb} / \mathrm{ft}^{3}\right)$ & 16.02 & kilogram per cubic meter $\left(\mathrm{kg} / \mathrm{m}^{3}\right)$ \\
\hline
\end{tabular}

Temperature in degrees Fahrenheit $\left({ }^{\circ} \mathrm{F}\right)$ may be converted to degrees Celsius $\left({ }^{\circ} \mathrm{C}\right)$ as follows:

$$
{ }^{\circ} \mathrm{C}=\left({ }^{\circ} \mathrm{F}-32\right) / 1.8
$$

Temperature in degrees Celsius $\left({ }^{\circ} \mathrm{C}\right)$ may be converted to degrees Fahrenheit $\left({ }^{\circ} \mathrm{F}\right)$ as follows:

$$
{ }^{\circ} \mathrm{F}=\left(1.8 x^{\circ} \mathrm{C}\right)+32
$$

Vertical coordinate information was referenced to the National American Vertical Datum of 1988 (NAVD 88), referred to in this report as "sea level."

Horizontal coordinate information was referenced to the North American Datum of 1983

(NAD 83).

Elevation, as used in this report, refers to distance above or below sea level.

\section{Abbreviations}

NYSDEC New York State Department of Environmental Conservation

SUTRA Saturated-Unsaturated TRAnsport

USGS U.S. Geological Survey 
This page has been left blank intentionally. 


\title{
Simulation of Groundwater Flow Pathlines and Freshwater/Saltwater Transition Zone Movement, Manhasset Neck, Nassau County, New York
}

\author{
By Paul Misut and Omkar Aphale
}

\section{Abstract}

A density-dependent groundwater flow and solute transport model of Manhasset Neck, Long Island, New York, was used to analyze (1) the effects of seasonal stress on the position of the freshwater/saltwater transition zone and (2) groundwater flowpaths. The following were used in the simulation: 182 transient stress periods, representing the historical record from 1920 to 2011, and 44 transient stress periods, representing future hypothetical conditions from 2011 to 2030. Simulated water-level and salinity (chloride concentration) values are compared with values from a previously developed two-stress-period (1905-1944 and 1945-2005) model. The 182-stress-period model produced salinity (chloride concentration) values that more accurately matched the observed salinity (chloride concentration) values in response to hydrologic stress than did the twostress-period model, and salinity ranged from zero to about 3 parts per thousand (equivalent to zero to 1,660 milligrams per liter chloride). The 182-stress-period model produced improved calibration statistics of water-level measurements made throughout the study area than did the two-stress-period model, reducing the Lloyd aquifer root mean square error from 7.0 to 5.2 feet. Decreasing horizontal and vertical hydraulic conductivities (fixed anisotropy ratio) of the Lloyd and North Shore aquifers by 20 percent resulted in nearly doubling the simulated salinity(chloride concentration) increase at Port Washington observation well N12508. Groundwater flowpath analysis was completed for 24 production wells to delineate water source areas. The freshwater/saltwater transition zone moved toward and(or) away from wells during future hypothetical scenarios.

\section{Introduction}

Planning for the future of Manhasset Neck, Nassau County, Long Island, New York, (fig. 1) requires identifying and protecting groundwater-source areas of pumped wells and an understanding of the potential for saltwater intrusion. The need for an improved understanding of density-dependent groundwater flow and solute transport prompted the U.S. Geological Survey (USGS), in cooperation with the Town of North Hempstead and the New York State Department of Environmental Conservation (NYSDEC), to develop numerical models to analyze the effects of pumping on groundwater levels and movement of the freshwater/saltwater transition zone, and to delineate water-particle pathlines. Monti and others (2009) used the USGS three-dimensional flow model SUTRA (Saturated-Unsaturated TRAnsport) (Voss and others, 1997) to simulate two multi-year pumping and recharge periods representing the years 1905 to 2005 to determine the effects of pumping. More detailed representation of changes in stress was obtained in the present study using the alternative USGS model SEAWAT (Langevin and others, 2007) with 182 stress periods representing the years 1920 to 2030. SEAWAT model enhancements to the initial SUTRA model configuration include simulation of unconfined conditions, greater model-domain area, head-dependent flow boundary representation of streams, seasonal representation of recharge and pumping, longer total model simulation time, and automated parameter estimation (Misut and Monti, 2009). The SEAWAT model generated greater dynamic response to change in stress and showed greater sensitivity to parameter variation than SUTRA. Finally, because SEAWAT is part of the USGS MODFLOW family of codes that include the particle tracker MODPATH (Pollock, 1994), it was possible to use MODPATH to delineate groundwater flowpaths to help inform decisions about protection of the water source for production wells.

The objective of this project was to assess the effects of groundwater withdrawals and variation in groundwater recharge on the following aquifer metrics: (1) groundwater levels, (2) the position of the freshwater/saltwater transition zone, (3) delineation of particle pathlines to pumped wells, and (4) delineation particle pathlines of water introduced at contaminated sites. This work updates a previous USGS model (Monti and others, 2009) with additional data, introduces more resolution into the new model, and uses the new model to answer questions that were not previously addressed. 


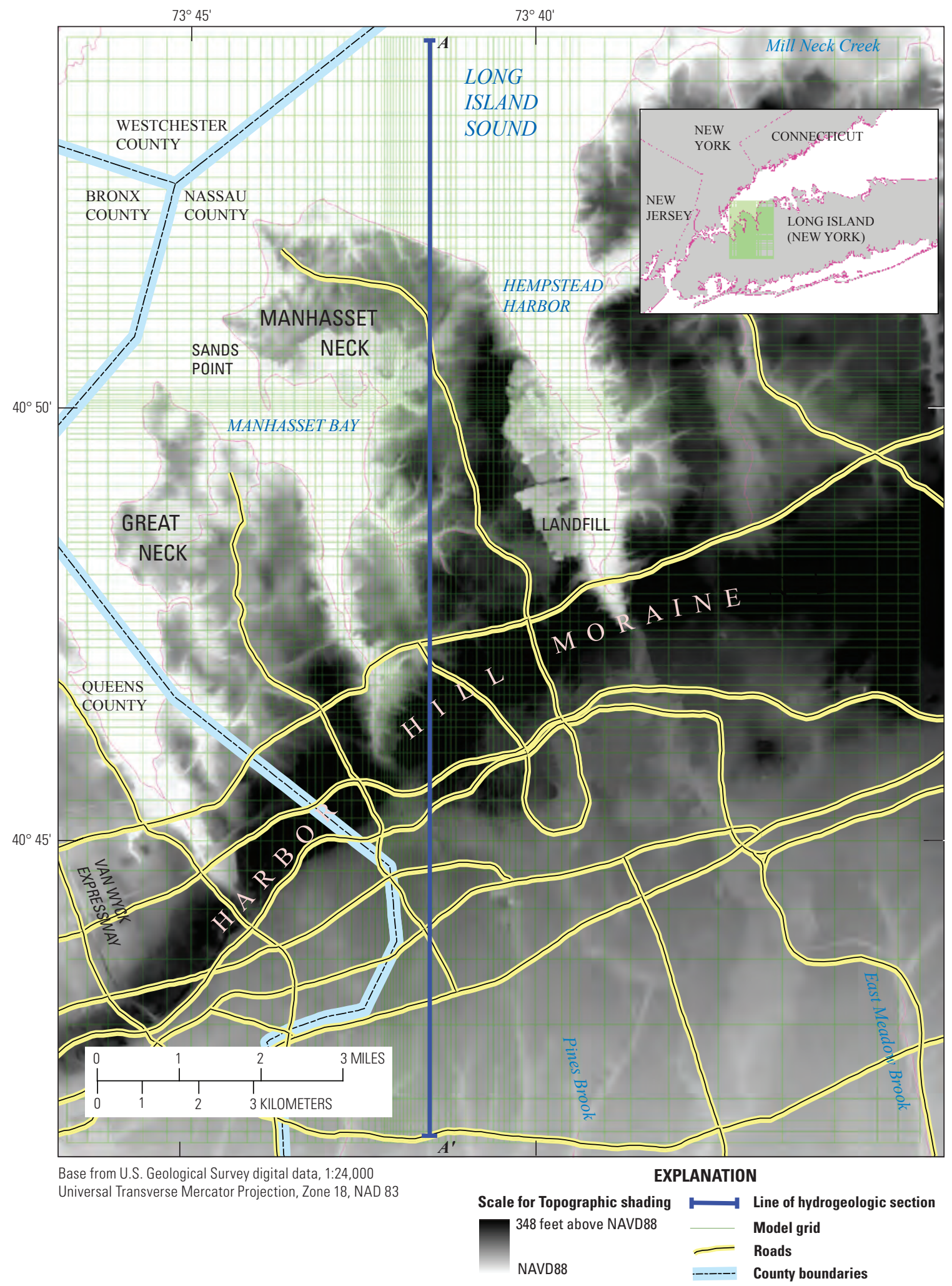

Figure 1. Location of the study area Manhasset Neck, Nassau County, New York, with the SEAWAT model grid. 


\section{Purpose and Scope}

This report documents the development and calibration of a SEAWAT model to simulate groundwater flow and solute transport beneath Manhasset Neck, Nassau County, New York, from 1920 to 2030. This report presents information used for model construction, provides an assessment of model performance in simulating hydrologic conditions observed in the field by USGS, and presents model limitations. The factors affecting groundwater recharge and discharge, and changes in salinity (chloride concentration), are discussed. Water budgets are presented in tables, and factors affecting groundwater recharge and discharge, and changes in salinity (chloride concentration), are presented in figures.

\section{Description of Study Area}

The Manhasset Neck encompasses about 19 square miles $\left(\mathrm{mi}^{2}\right)$ and is bordered by Long Island Sound to the north, Manhasset Bay to the west, Hempstead Harbor to the east, and the Harbor Hill Moraine to the south (fig. 1). In 2000, Manhasset Neck had about 54,000 residents (Long Island Power Authority, 2004) with residential land representing about 59 percent of the study area (U.S. Geological Survey, 2002). Manhasset Neck is thoroughly described in Monti and others (2009). Groundwater flow on the Manhasset Neck Peninsula is affected by factors that extend beyond the Neck proper into a greater area (fig. 1) of about $140 \mathrm{mi}^{2}$ in Nassau and Queens Counties. Therefore, the Manhasset Neck model boundary is bordered by the mainland New York State (Westchester County) to the northwest, Mill Neck Creek to the northeast, East Meadow Brook to the southeast, and the Van Wyck Expressway to the southwest (fig. 1). The study area has a temperate climate with hot, humid summers and mild winters. Average annual temperature was about 55.5 degrees Fahrenheit ( $\left.{ }^{\circ} \mathrm{F}\right)$ in 2010 (Horton and others, 2010). Most of the groundwater recharge (about 20 inches per year) occurs in the non-growing season (Franke and McClymonds, 1972). Drought during the middle to late 1960s affected water levels in wells under unconfined conditions, while water levels in deeper confined wells showed a greater influence from pumping and did not respond to the drought condition as dramatically (Franke and McClymonds, 1972). Land-surface elevation in the study area ranges from $348 \mathrm{ft}$ above NAVD 88 at the Harbor Hill Moraine to about $116 \mathrm{ft}$ below NAVD 88 at the Long Island Sound seafloor north of Sands Point (fig. 1).

Well-numbering system.-Wells on Long Island, New York, are numbered serially by county. The number is prefixed by the first letter of the county name; for example, well N6294 in Nassau County. Numbers are assigned in sequence by New York State as permits to drill are issued and have no relation to the location of wells within the county. Wells mentioned throughout this report are listed in appendix 1 (back of report).

\section{Groundwater-Flow System}

This section describes characteristics of the groundwaterflow system in the study area, including the hydrogeologic framework, recharge, groundwater-flow directions, discharge, exchange of water between the aquifer system and creeks, temporal fluctuations in groundwater levels, and water budget. This information was used to construct and calibrate the numerical model, which builds on the work of Monti and others (2009).

The geologic and hydrologic units that form Long Island's hydrogeologic framework are described by Suter and others (1949), Perlmutter and Geraghty (1963), Swarzenski (1963), Kilburn (1979), and Smolensky and others (1989). Geologic correlations are revised from those of Kilburn (1979), Swarzenski (1963), and Fuller (1914). "Interpretation of hydrogeologic units by Stumm and others (2002) named the North Shore confining unit and the North Shore aquifer within Manhasset Neck.

\section{Hydrogeologic Units}

Unconsolidated hydrogeologic units of Pleistocene and Cretaceous age (table 1) overlie the crystalline bedrock of the Cambrian-Ordovician aged Hartland Formation. The upper part of the bedrock is weathered, except possibly in some of the buried valleys where the saprolitic zone may have been completely eroded during the Pleistocene Epoch. Some erosional features are mapped by Stumm and others (2002); however, available information is generally too limited to delineate some of the irregularities of the erosional features that undoubtedly exist on the surface of the bedrock.

The Lloyd aquifer of Cretaceous age overlies the bedrock and, in turn, is generally overlain by the Cretaceous Raritan confining unit (Swarzenski, 1963). The Lloyd aquifer is not present in either the northwestern or the central parts of Manhasset Neck but does underlie the southern part. The Raritan confining unit is present south of the central regions of Manhasset Bay and Hempstead Harbor and along the eastern part of Manhasset Neck. The Magothy aquifer, the uppermost Cretaceous aquifer, is an upward-fining sequence of sands. The Magothy aquifer is mostly absent, present only in the southern part of Manhasset Neck where it overlies the Raritan confining unit. South of Manhasset Neck, the Magothy aquifer is the water-table aquifer. The productive water-bearing zones in the Magothy aquifer consist of thin zones of sand and grave1, which occur at various depths as scattered, discontinuous lenses in the predominantly finegrained material, and a thicker, more extensive coarse-grained zone near the base of the aquifer (Swarzenski, 1963). The basal coarse-grained zone is extensively distributed south of Manhasset Neck but is apparently not as extensive in Manhasset Neck. This basal zone comprises coarse quartz sand and gravel, varying amounts of interstitial clay, and some layers of clay and sandy clay. 
Table 1. Characteristics of hydrogeologic units, Manhasset Neck, New York.

[From Stumm and others, 2002, table 2]

\begin{tabular}{|c|c|c|}
\hline Hydrogeologic unit & Geologic unit & Description and hydraulic properties \\
\hline Upper glacial aquifer & Upper Pleistocene deposits & $\begin{array}{l}\text { Till and outwash deposits of sand, silt, clay, and boulders. Varied } \\
\text { permeability with an average hydraulic conductivity of } 270 \text { feet per } \\
\text { day and an anisotropy of 10:1. Outwash has the highest hydraulic } \\
\text { conductivity. }\end{array}$ \\
\hline North Shore aquifer & Pleistocene deposits & $\begin{array}{l}\text { Sand, silt, and gravel; brown and olive gray, poor to moderate sorting. } \\
\text { Moderately permeable. }\end{array}$ \\
\hline Bedrock & $\begin{array}{l}\text { Hartland Formation; } \\
\text { crystalline bedrock }\end{array}$ & $\begin{array}{l}\text { Highly weathered biotite-garnet-schist with low hydraulic conductivity. } \\
\text { A thick saprolitic zone } 50 \text { to } 100 \text { feet thick, consisting of white, } \\
\text { yellow, and gray clay, underlies most of the peninsula except in the } \\
\text { northernmost part. Impermeable to poorly permeable. }\end{array}$ \\
\hline
\end{tabular}

The North Shore aquifer (Stumm and others, 2002) consists of a sequence of Pleistocene-age sediments overlying bedrock that is mostly confined by the North Shore confining unit and is hydraulically connected to the Lloyd aquifer within buried valleys where the Raritan confining unit has been removed. The North Shore aquifer is unconfined in a small, isolated area in the northwestern part of the study area near Sands Point (fig. 1). The upper glacial aquifer consists of till and outwash deposited during the Wisconsin glaciation of the Pleistocene Epoch. The wide range in the lithology of the Pleistocene deposits affects the occurrence and movement of groundwater beneath Manhasset Neck. In areas underlain by low permeability materials, the downward movement of water from precipitation is limited.

\section{Hydraulic Properties}

Hydraulic conductivity was estimated for the hydrogeologic units using specific-capacity data from drillers' logs and other methods. Hydraulic properties are summarized in table 1 (Stumm and others 2002). The values of estimated hydraulic conductivity for the aquifers are similar in magnitude to values reported by Freeze and Cherry (1979) for similar materials. Effective porosity values for aquifers range from 15 percent (Misut and others, 2003) to 30 percent
(Franke and Cohen, 1972), whereas the confining units average 20 percent (McWorter and Sunada, 1977). Values for storage applied in previous modeling studies on Long Island are summarized by Buxton and Smolensky (1999). Specificyield values range from 0.1 (Magothy aquifer) to 0.3 (glacial outwash), and specific storage is $6.0 \times 10^{-7}$ per foot for all confining units. Jacob (1941) estimated the specific storage of Lloyd aquifer to be $1.3 \times 10^{-6} / \mathrm{ft}$, and Misut and Busciolano (2010) estimated storativity of the upper Magothy to be 0.003 .

\section{Recharge}

Precipitation is the dominant source of water recharging the groundwater system. Factors affecting rates of recharge are (1) spatial and temporal variations in precipitation, (2) permeability of surficial hydrogeologic units, (3) landcover characteristics, (4) discharge of low-density residential wastewater into cesspools and septic tanks, and (5) losses from public sewer systems. Irrigation water is typically evaporated or transpired except in cases of over-watering when recharge may occur. Average precipitation is 42 inches annually (Miller and Fredrick, 1969). For predevelopment conditions, about 50 percent of the precipitation reached the aquifers, mainly during the non-growing season (Aronson and Seaburn, 1974; Franke and McClymonds, 1972). For 
developed conditions, groundwater recharge is mainly from (1) infiltration of precipitation through unpaved areas, (2) infiltration of storm runoff through recharge basins, and (3) infiltration of wastewater through septic systems. Densely developed areas on Manhasset Neck, where impervious areas and stormwater-management systems promote runoff to bays and thereby diminish recharge, include Manorhaven Village, Port Washington Business District, Hempstead Harbor Industrial Park, and the State Route 25A commercial corridor (fig. 2). Runoff is also routed to an extensive network of stormwater recharge basins, thereby redistributing and enhancing groundwater recharge to the deep flow systems of the Magothy and Lloyd aquifers. At the southern boundary of the model, stormwater runoff is routed into the headwaters of south-flowing stream channels, including East Meadow Brook and Pines Brook, which generally lose water to the underlying upper glacial aquifer.

\section{Discharge and Pumping}

Groundwater in the study area discharges (1) as seepage to freshwater streams, lakes, and wetlands; (2) as submarine seepage to tidal wetlands; (3) as evapotranspiration from areas having a shallow depth to the water table; and (4) as withdrawals from wells. The USGS has measured flow at about 10 streams in the study area, including Whitney Lake Outlet (01302200), a low-flow partial-record station with 124 discrete measurements from 1953 to 2010; and Roslyn Brook (01302300), another low-flow partial-record station with 130 discrete measurements from 1953 to 2010 . The mean annual discharge of Whitney Lake Outlet was estimated to be 1.30 cubic feet per second $\left(\mathrm{ft}^{3} / \mathrm{s}\right)$, whereas the estimate for mean annual discharge for Roslyn Brook was $0.64 \mathrm{ft}^{3} / \mathrm{s}$. Streamgages at Alley Creek (01302050) and Glen Cove Creek (01302500) were equipped with continuous water-stage recorders. The former has a drainage area of about $1.68 \mathrm{mi}^{2}$, and the latter has a drainage area of $14.4 \mathrm{mi}^{2}$. Alley Creek had a mean annual discharge of $1.86 \mathrm{ft}^{3} / \mathrm{s}$ for 1993 to 2009 , whereas Glen Cove Creek had a mean annual discharge of $7.35 \mathrm{ft}^{3} / \mathrm{s}$ for 1939 to 2009 (http://nwis.waterdata.usgs.gov; accessed 07/01/2011). The percentages of base flow and surface runoff for selected streams on the north shore of Long Island were calculated by Reynolds (1982) for 1960 to 1975. Reynolds (1982) indicates that an empirical relation between annual mean base flow and stream discharge at the 55-percent duration point can be used to estimate annual average base flow.

Wetland areas (fig. 3) of active evapotranspiration of shallow groundwater were delineated through an analysis of depth to groundwater (Monti and Busciolano, 2009. In addition, there are numerous small unnamed kettlehole ponds in the morainal areas where evapotranspiration is likely to be enhanced.

Well pumping increased from a 1920 total of about 3 million gallons per day (Mgal/d) in the study area (fig. 1) and about $1 \mathrm{Mgal} / \mathrm{d}$ on the Manhasset Neck Peninsula to a 1950 total of about $20 \mathrm{Mgal} / \mathrm{d}$ in the study area (fig. 1) and about $3 \mathrm{Mgal} / \mathrm{d}$ on the Manhasset Neck Peninsula, a 2000 total of about $35 \mathrm{Mgal} / \mathrm{d}$ in the study area (fig. 1) and about $3 \mathrm{Mgal} / \mathrm{d}$ on the Manhasset Neck Peninsula (Monti and others, 2009). In 2006, 13 production wells within the study area in the Lloyd, Magothy, and North Shore aquifers exceeded an annual average pumping rate of $1 \mathrm{Mgal} / \mathrm{d}$, as reported to NYSDEC (William Spitz, written communication, 2011, fig. 4). These production wells (fig. 4) are distributed as follows: a cluster of wells in the Sea Cliff area east of Manhasset Neck (well N9210, N9211, N9334, N5762, and N5792), a crescent of wells on the Nassau side of the Nassau/ Queens County border (well N7512, N17, N7560, N5156, N10206, and N8979), one high-capacity production well operated by the New York City Department of Environmental Protection (NYCDEP) in Queens County (Q 305), and one production well operated in Mineola (N10034)). In June 2006, high-capacity production well N15310 was put into service at Christopher Morley Park (fig. 4), near the south end of the Manhasset Neck. In addition to production wells, there are about five industrial/commercial wells on Manhasset Neck, pumping at annual average pumpage rates less than $1 \mathrm{Mgal} / \mathrm{d}$, as reported to NYSDEC (William Spitz, written commun., 2011). All average annual well pumping rates for years 1920 through 2006 are given in the model file archive accompanying this report.

\section{Groundwater-Flow Directions}

Groundwater generally flows from areas of higher hydraulic head in the center of the Manhasset Neck outward toward areas of discharge around the shoreline in the upper glacial aquifer. There are local zones of deep recharge on Manhasset Neck where confining units are absent. Groundwater moving along deep flowpaths enters Manhasset Neck from the south and east. General pre-pumping condition groundwater flowpaths that affect Manhasset Neck are (1) downward flow of groundwater recharge from precipitation; (2) flow from the upper glacial aquifer into Manhasset Neck; (3) flow from the upper glacial aquifer towards points of stream, shoreline, and subsea discharge; (4) downward recharge into the Magothy aquifer south of Manhasset Neck; (5) northward flow from the Magothy aquifer into Manhasset Neck; (6) northward flow from the Lloyd aquifer into Manhasset Neck; (7) northward discharge from the Lloyd aquifer into the North Shore aquifer and (8) downward flow of upper glacial groundwater into the North Shore aquifer in several locations; (9) downward flow across the Raritan confining unit into the Lloyd aquifer; and (10) flows at study area boundaries off Manhasset Neck, both recharging and discharging. These generalized flowpaths are illustrated in cross-sectional view in figure 5. In addition to pre-pumping condition flowpaths, presently groundwater also flows towards pumping well screens. Large cones of depression have been mapped and simulated (Monti and 


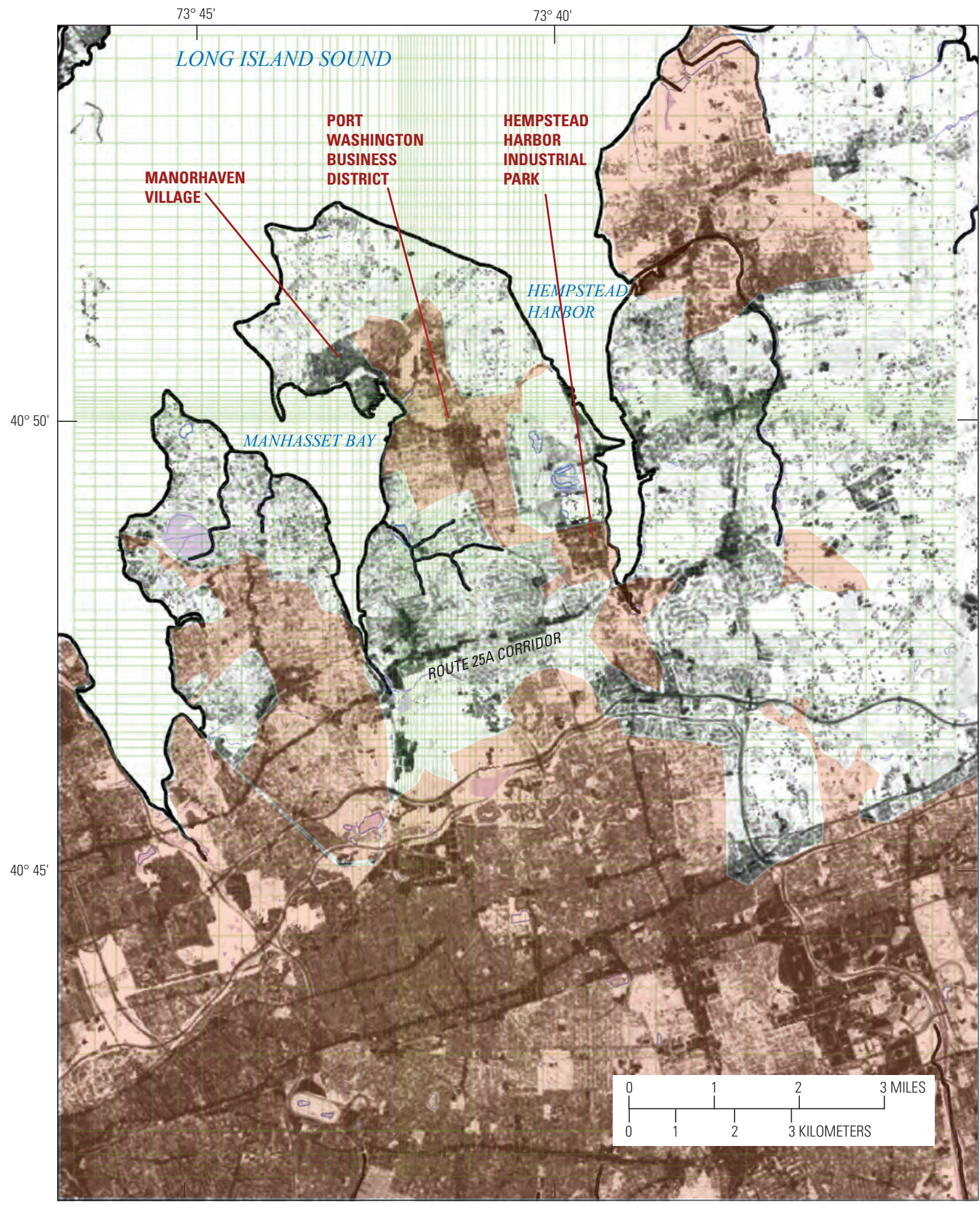

Base from U.S. Geological Survey digital data, 1:24,000 Universal Transverse Mercator Projection, Zone 18, NAD 83

EXPLANATION

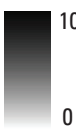

Impervious area, in percent-Data are from U.S. Geological Survey national land use/land cover dataset

Sewered area, from Nassau County Department of Public Works (2013) Wetland-As identified by New York State Department of Environmental Conservation Streams and ponds

Model grid

Figure 2. Location of the wetlands and impervious areas, Manhasset Neck, New York. (U.S. Geological Survey) 


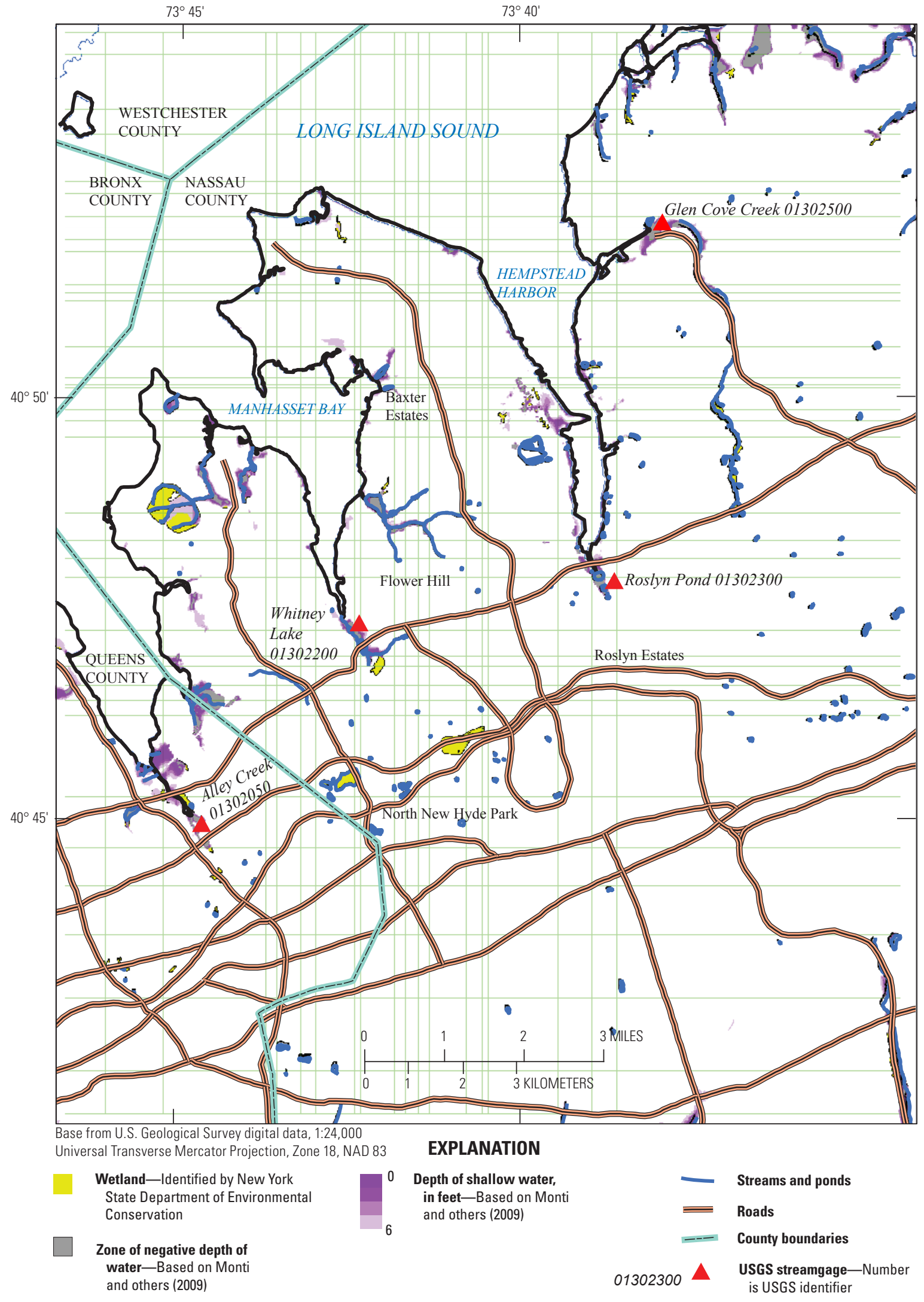

Figure 3. Location of US. Geological Survey streamgages, wetlands, and depth of shallow water, Manhasset Neck, New York. 


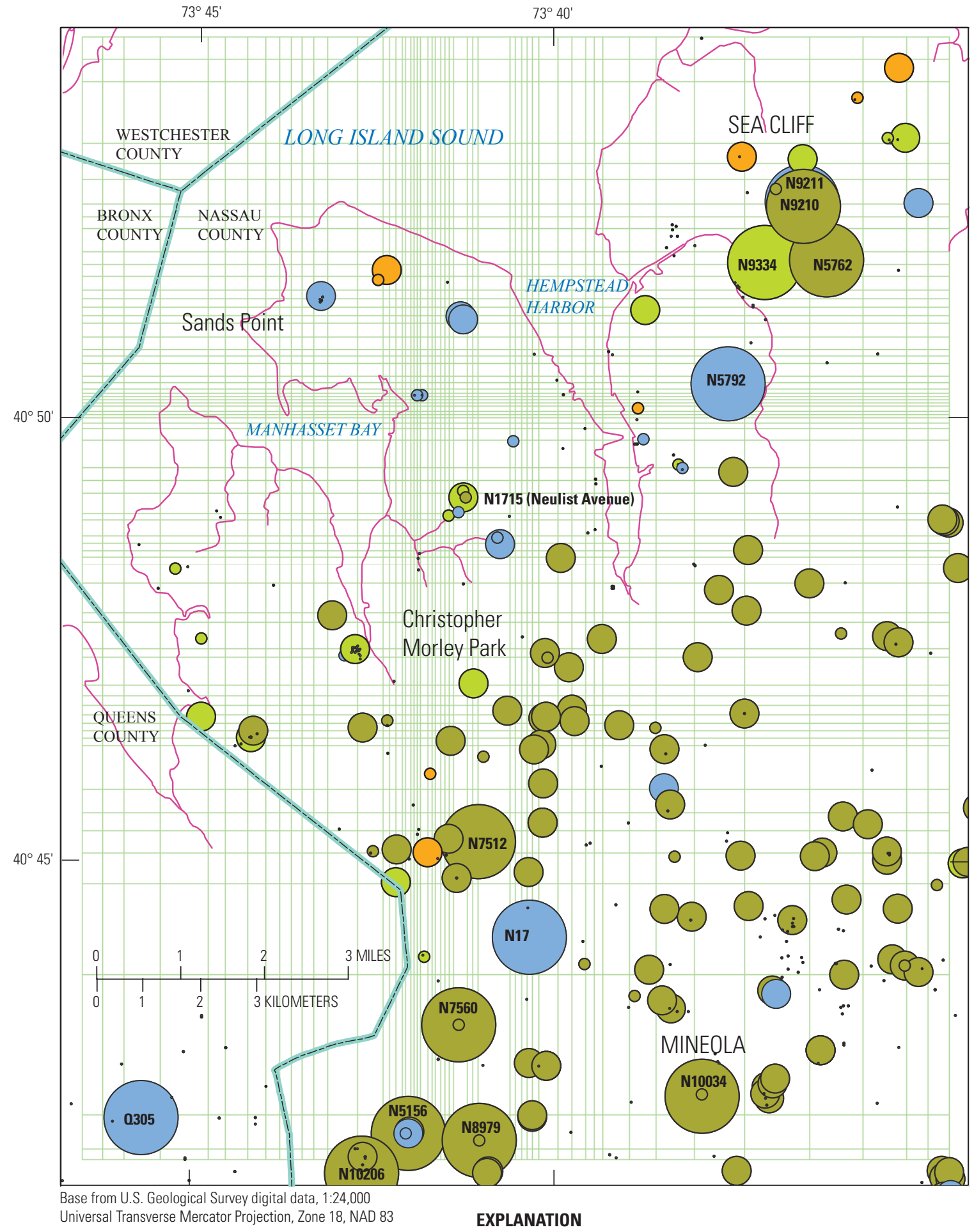

Production well with annual pumpage rates for 2006, in million gallons per day. Color corresponds to aquifer shown in figure 5 . Selected well numbers are given.

- No pumpage $\quad \circ \quad .01$ to .less than $.1 \bigcirc .1$ to less than 1

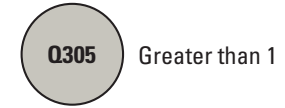

Figure 4. Annual pumpage rates of production wells on and near Manhasset Neck, New York, 2006. 


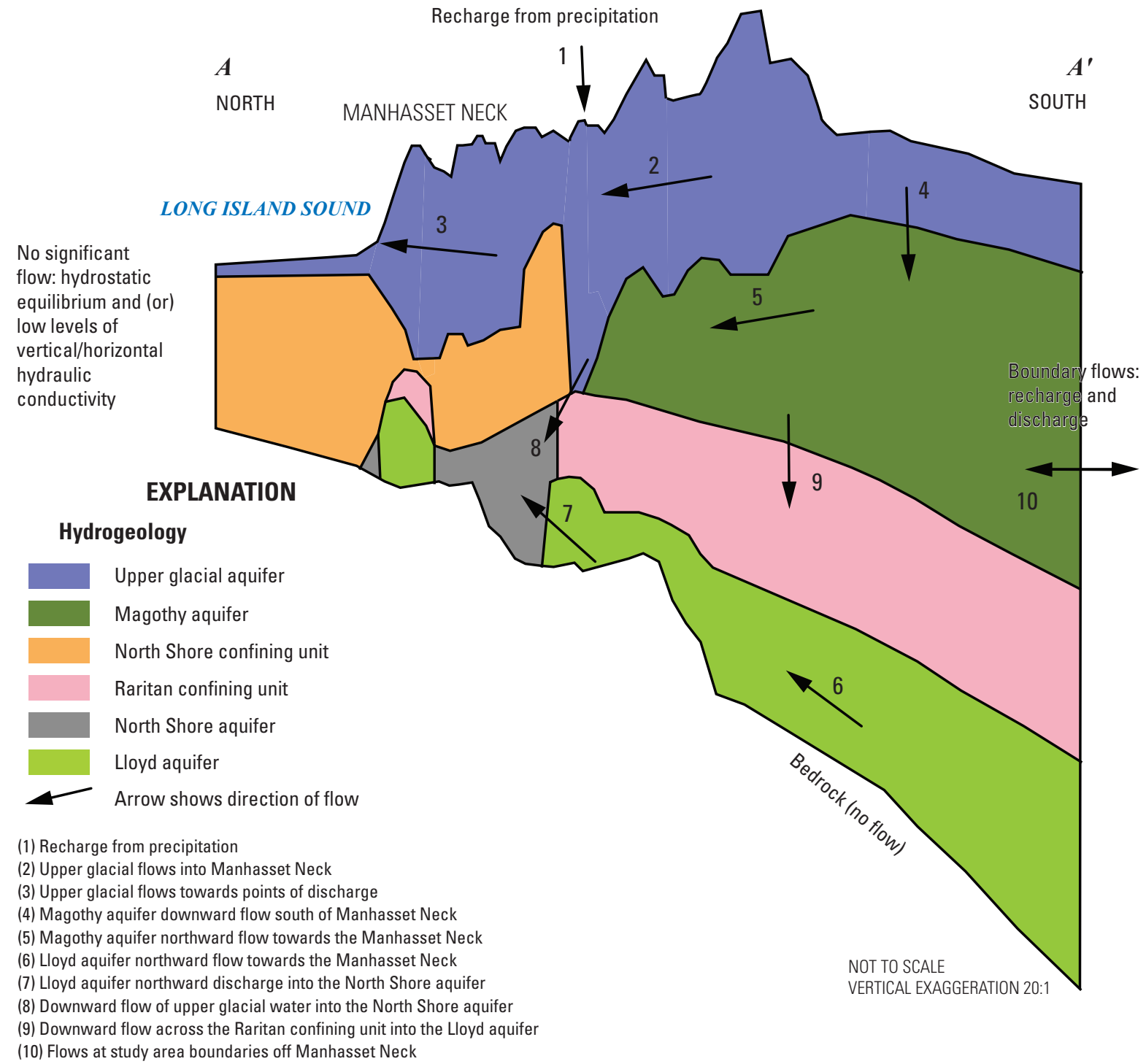

Figure 5. Schematic section showing groundwater flow patterns, Manhasset Neck, New York. (Modified from Monti and others, 2009). (Location of section shown in fig. 1) 
others, 2009) and indicate that this lowering of groundwater levels in the confined Lloyd and North Shore aquifers has reversed the natural groundwater flow direction from the land to the surrounding embayments and extends beyond the Manhasset Neck Peninsula.

\section{Freshwater/Saltwater Transition Zone}

Freshwater/saltwater transition zones associated with production wells were mapped by Stumm and others (2002) based on data from many production and observation wells, and are shown and updated in figure 6. Saline water tends to sink beneath freshwater because it has a greater density than freshwater. The size and shape of the transition zone between saline water and fresh groundwater results from a combination of convection, advection, hydrodynamic dispersion, and chemical diffusion. The transition zone shifts in response to increases or decreases in groundwater recharge and discharge; for example, overpumping of wells may cause saltwater intrusion, in turn, resulting in a degradation of groundwater quality. Some production wells have already been impacted by saltwater intrusion, including N35; others are anticipated to be impacted, including N1715 and N36 (Stumm and others, 2002). Prevention of the landward movement of the transition zone requires that freshwater is discharged from the aquifer at a rate sufficient to keep the transition zone at a stable location.

During predevelopment conditions, there was sufficient pressure from fresh groundwater in most onshore areas of Manhasset Neck to fully support freshwater conditions within the aquifers from the water table down to the bedrock. Furthermore, in locations such as northeastern Manhasset Bay, (fig. 1) the configuration of freshwater/saltwater transition zone was inverted during predevelopment conditions such that denser saltwater near the seafloor overlay deep freshwater zones in the aquifer where aquifer heads built up under confining layers and deep freshwater flowed from the south. The location of the freshwater/saltwater transition zone in the near offshore region was variable and affected by local factors, including hydrogeologic framework and hydrologic stress. The major hydrologic stress is clearly public supply and golf course pumpage from the confined Lloyd and North Shore aquifers. Groundwater has a salinity (chloride concentration) equal to that of Long Island Sound surface water in the far offshore region, and it is in hydrostatic equilibrium with atmospheric pressure at the sea surface. The contribution to regional landward movement of the freshwater/saltwater transition zone by a natural sea-level rise of about $1 \mathrm{ft}$ during the 20th century (Horton and others, 2010) is minor in comparison to the 5- to 10 - $\mathrm{ft}$ groundwater-level drawdowns produced by groundwater withdrawals and seen at observation wells on the peninsula. Freshwater/saltwater transition zone movements have been recently observed and summarized by (Stumm, written communication, 2012.) Recent screenzone sampling of observation wells and collected borehole geophysical logs indicate worsening conditions on the peninsula. Changes in salinity (chloride concentration) estimated from geophysical logs are available for observation wells N12793 and N12508 at Port Washington, and for observation well N12318 at Sands Point (fig. 6). In zones of increasing salinity, chloride concentration increase may be interpreted to be about 5 times the increase in millisiemens per meter (for example, at about 375 feet below land surface at well N12793, electromagnetic conductivity has increased by about 30 millisiemens per meter from 1997 to 2008, corresponding to a chloride concentration increase of about 150 milligrams per liter $(\mathrm{mg} / \mathrm{L}))$. Electromagnetic logs show increased conductivity over time in both shallow and deep confined zones. At well N12793, three zones of increasing conductivity are evident; at wells N12508 and N12318, two zones are evident. Salinity in this report is shown with chloride concentration because the movement of the freshwater/ saltwater transition zone depends on density variation between freshwater and saltwater, and density is more directly linked to salinity than to chloride concentration (most of the added weight of saline water is due to solutes other than chloride.) Salinity refers to the amount of salts dissolved in water, is directly responsible for density variation, and is thus used in density-dependent flow modeling (Langevin, 2007). In addition to estimating salinity from electromagnetic logs showing conductivity, salinity may be extrapolated from easily analyzed components of the total salt content, such as chloride concentration. Sampled chloride data may not represent the maximum salinity in the aquifer because a physical sample is taken from one point, while the geophysical logs can show the entire aquifer.

\section{Water Budget}

Water budgets from the SUTRA model for three periods (predevelopment, 1905 to 1944, and 1945 to 2005) are discussed in detail in Monti and others (2009) for the area shown in figure 7 and are summarized in table 2. The wells involved in the pumping during the three SUTRA model periods are given in the SUTRA modeling report (Monti and other, 2009). Recharge from precipitation was held constant for all periods. Pumping not only captured water that would have discharged naturally to saltwater bodies but also promoted additional lateral recharge at the model boundaries. For example, during 1905-44, discharge to Hempstead Harbor decreased from 50.1 to 48.1 million gallons per day (Mgal/d), and lateral inflow from the eastern model boundary increased from 46.2 to $48.7 \mathrm{Mgal} / \mathrm{d}$. These changes partly offset the increase in pumpage from zero (predevelopment condition) to $12.1 \mathrm{Mgal} / \mathrm{d}$ and resulted in landward movement of the freshwater/ saltwater transition zone, leading to saltwater intrusion into wells such as N35 in the Lloyd and North Shore aquifers. 
$\boldsymbol{A}$

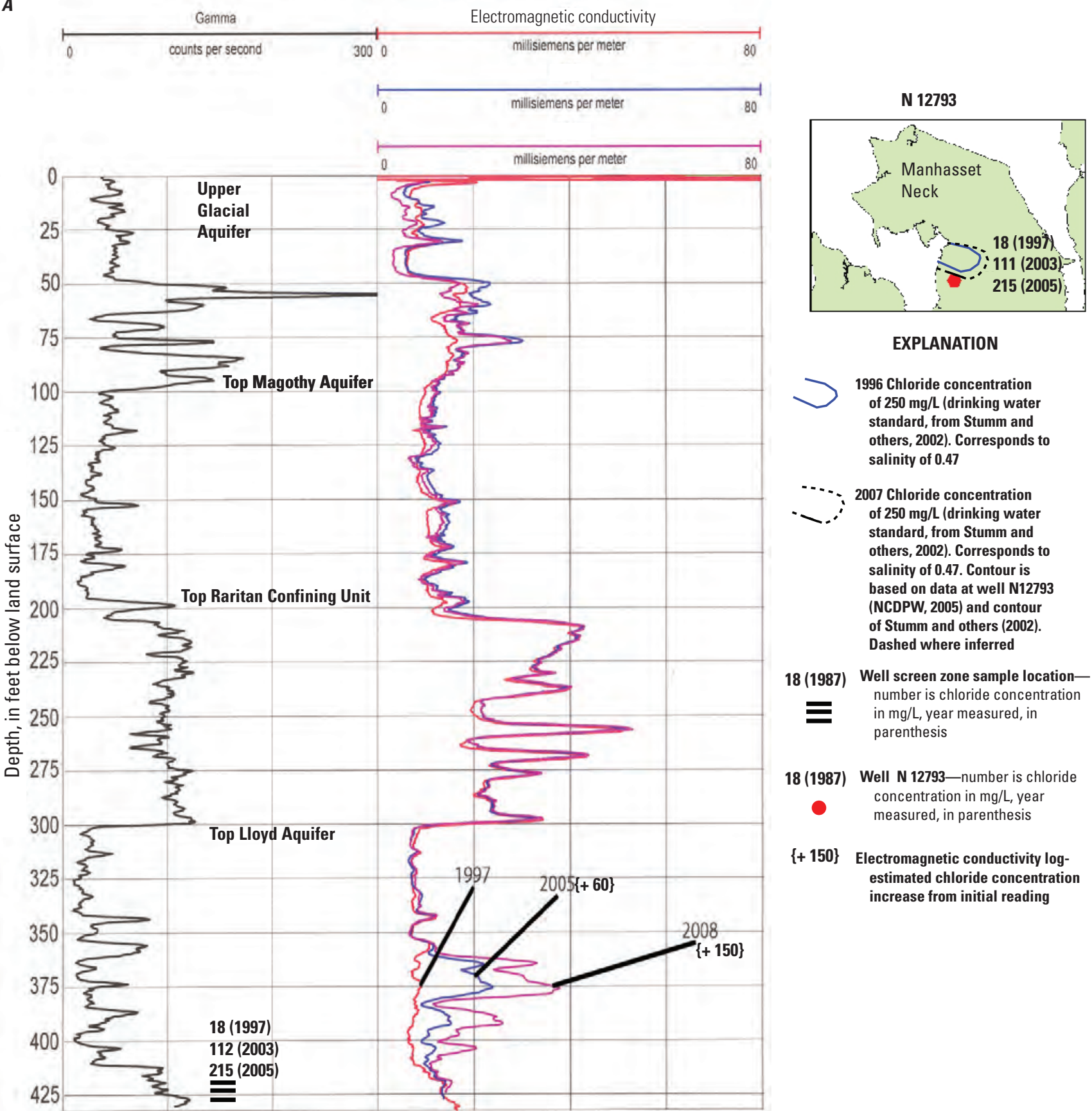

Figure 6. Geophysical logs of observation wells $A, \mathrm{~N} 12793, B, \mathrm{~N} 12508$, and $C, \mathrm{~N} 12318$ showing salinity (chloride concentration) change, Manhasset Neck, New York, 1994-2008. (Frederick Stumm, U.S. Geological Survey, written commun., 2012). (NCDPW, Nassau County Department of Public Works, mg/L, milligrams per liter). 
B

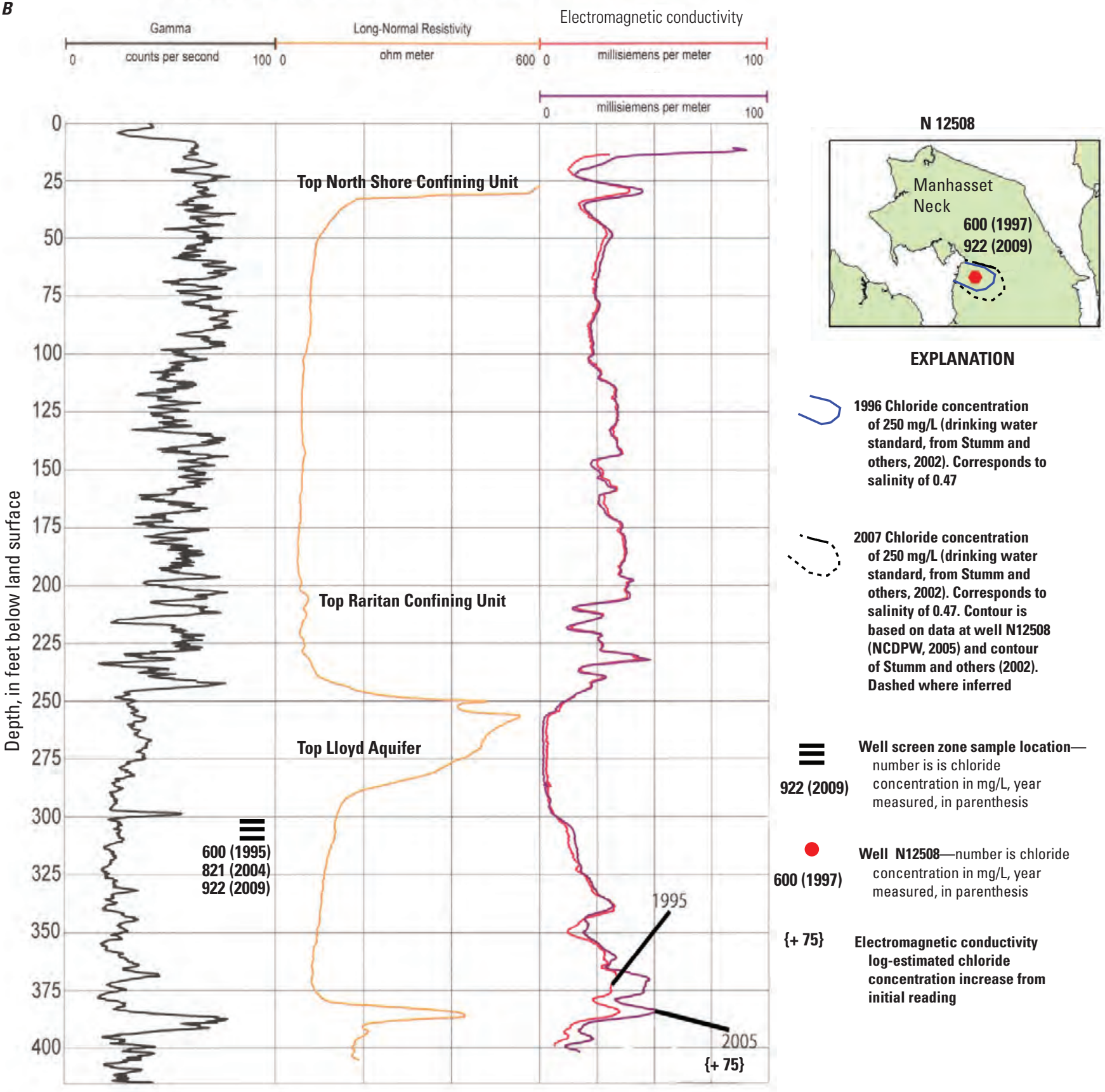

Figure 6. Geophysical logs of observation wells $A, \mathrm{~N} 12793, B, \mathrm{~N} 12508$, and $C, \mathrm{~N} 12318$ showing salinity (chloride concentration) change, Manhasset Neck, New York, 1994-2008. (Frederick Stumm, U.S. Geological Survey, written commun., 2012). (NCDPW, Nassau County Department of Public Works, mg/L, milligrams per liter).-Continued 


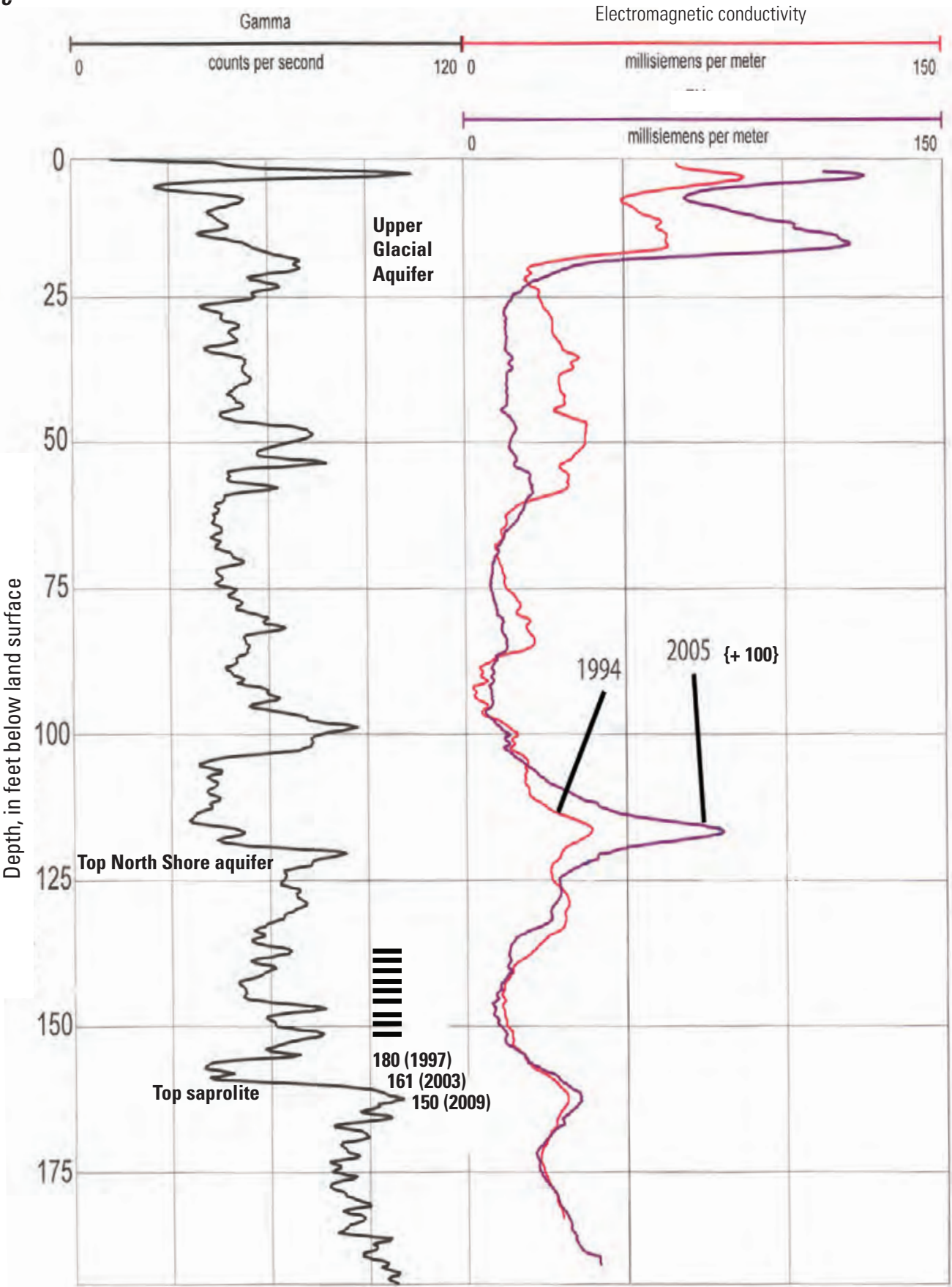

N 12318

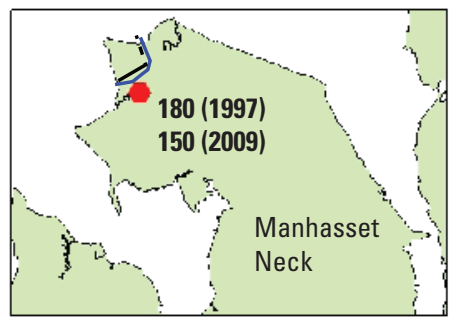

EXPLANATION

J 1996 Chloride concentration of $250 \mathrm{mg} / \mathrm{L}$ (drinking water standard, from Stumm and others, 2002). Corresponds

to salinity of 0.47

i $\quad 2007$ Chloride concentration of $250 \mathrm{mg} / \mathrm{L}$ (drinking water standard, from Stumm and others, 2002). Corresponds to salinity of 0.47 . Contour is based on data at well N12318 (NCDPW, 2005) and contour of Stumm and others (2002). Dashed where inferred

\section{- Well screen zone sample location-number is chloride concentration in $\mathrm{mg} / \mathrm{L}$, year measured, in parenthesis}

Well N 12318 - number is 180 (1997) chloride concentration in $\mathrm{mg} / \mathrm{L}$, year measured in parenthesis

$\{+100\} \quad$ Electromagnetic conductivity log-estimated chloride concentration increase from initial reading

Figure 6. Geophysical logs of observation wells $A, N 12793, B, N 12508$, and $C, N 12318$ showing salinity (chloride concentration) change, Manhasset Neck, New York, 1994-2008. (Frederick Stumm, U.S. Geological Survey, written commun., 2012). (NCDPW, Nassau County Department of Public Works, mg/L, milligrams per liter).-Continued 


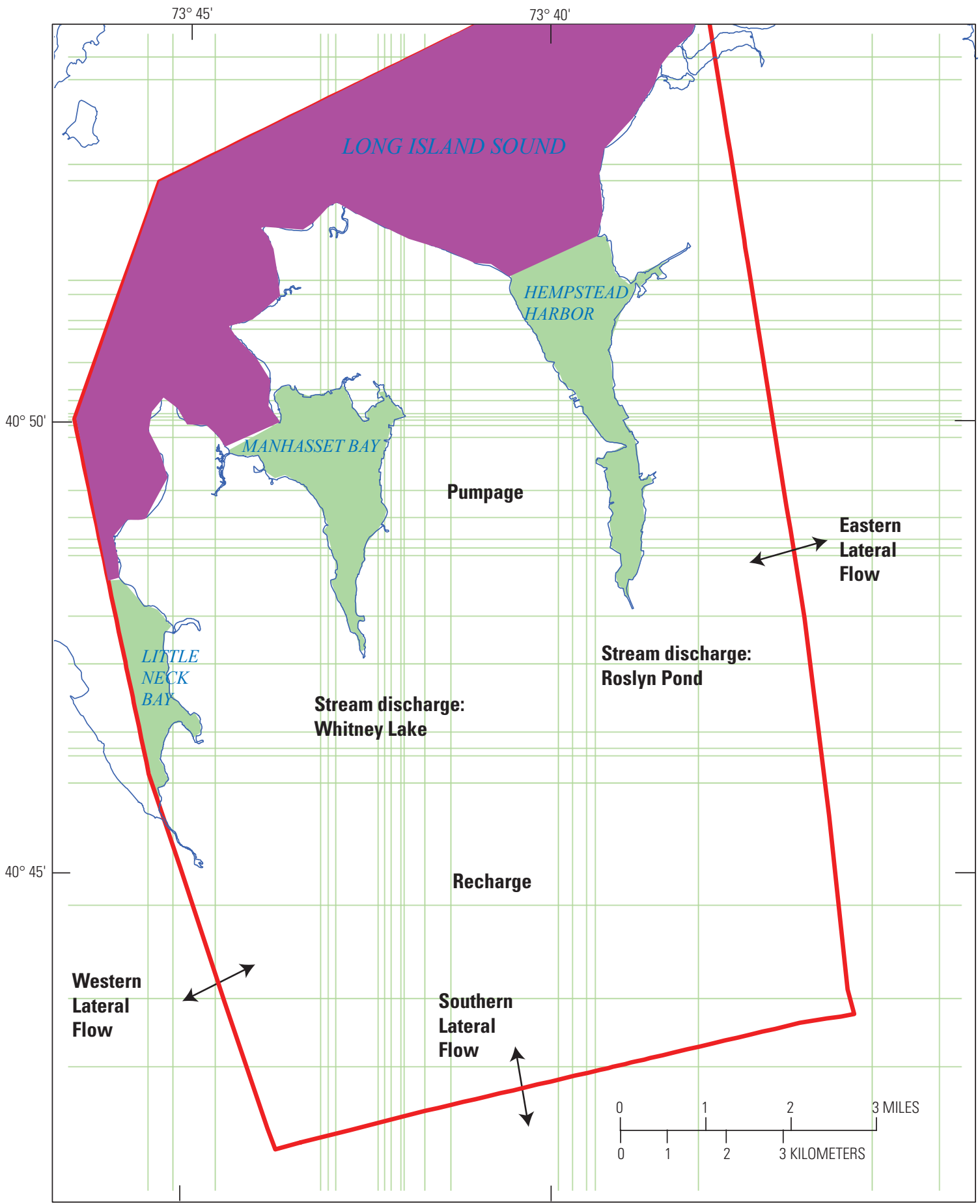

Base from U.S. Geological Survey digital data, 1:24,000

Universal Transverse Mercator Projection, Zone 18, NAD 83

\section{EXPLANATION}

Water budget area-Of finite-element SUTRA

model (Monti and others, 2009)

Model grid-Finite difference model

Figure 7. Location of water-budget components of a SUTRA finite-element model, Manhasset Neck, New York. 
Table 2. Groundwater budgets for three periods from the SUTRA model, Manhasset Neck, New York.

[From Monti and others, 2009. Values are in million gallons per day. Negative values indicate water leaving the model]

\begin{tabular}{lccc}
\hline \multicolumn{1}{c}{ Location } & Predevelopment period & 1905-1944 period & 1945-2005 period \\
\hline & \multicolumn{4}{c}{ Onshore } \\
\hline Recharge (precipitation) & 70.1 & 70.1 & 70.1 \\
Lateral flow or lateral inflow & & & \\
$\quad$ Eastern lateral boundary & 46.2 & 48.7 & 58.8 \\
$\quad$ Western lateral boundary & -7.8 & -6.7 & -4.1 \\
$\quad-17.7$ & -14.4 & -3.9 \\
Southern lateral boundary & 0 & -12.1 & -43.3 \\
Wells (pumpage) & -4 & -4 & -4 \\
Stream discharge & -8.9 & Offshore (subsea discharge) & -6.2 \\
& -13.2 & -8.0 & -8.4 \\
\hline Little Neck & -50.1 & -11.2 & -45.2 \\
Manhasset Bay & -14.8 & -48.1 & -14.0 \\
Hempstead Harbor & & -14.4 & \\
Long Island Sound & & & \\
\hline
\end{tabular}

\section{Simulation of Groundwater Pathlines and Freshwater/Saltwater Transition Zone Movement}

The effects of seasonal pumpage and recharge on groundwater-flow patterns and the freshwater/saltwater transition zone movement on Manhasset Neck were simulated by using SEAWAT (Langevin and others, 2007), a computer model that simulates three-dimensional flow using a modified version of MODFLOW-2000 (Harbaugh and others, 2000) and that simulates transport with a version of MT3DMS (Zheng and Wang, 1999). The SEAWAT model solves the variable-density flow equation over a finite-difference grid by formulating the matrix equations in terms of fluid mass with the assumption that fluid density is a linear function of solute concentration. Transport simulations used a migrating tracer, which was related to density by estimating salinity as a linear function of chloride concentration as follows (Langevin and others, 2007):

salinity (parts per thousand $)=$ chloride (parts per million) $\times 0.0018066$.

Therefore, a salinity of 1 part per thousand is approximately equal to a chloride concentration of 554 milligrams per liter $(\mathrm{mg} / \mathrm{L})$.
The advection part of the transport equation was solved by using a finite-difference method with upstream weighting. Remaining terms of the transport equation were solved by using an implicit finite-difference method. The flow and transport equations were explicitly coupled and solved alternately. The flow solution was updated whenever the maximum change in density at a single cell exceeded $5.0 \times 10^{-3}$ grams per cubic centimeter $\left(\mathrm{g} / \mathrm{cm}^{3}\right)$, or about 2.5 percent of the range in density. Model dispersivity was set to zero. The particle-tracking algorithm MODPATH6 (Pollock, 2012) was used in conjunction with SEAWAT to delineate groundwater flowpaths.

The model represented a 140-square mile $\left(\mathrm{mi}^{2}\right)$ area surrounding the Manhasset Neck (fig. 8). Subsea groundwater heads are likely to be in hydrostatic equilibrium with sea level (NAVD 88) and with the headwaters of south-flowing streams south of any groundwater source areas for Manhasset Neck. Areas north of the seafloor trough (fig. 8) of Long Island Sound are inactive. The modeled area was divided into 91 rows, 71 columns, and 19 layers, with cell dimensions ranging from $50 \mathrm{ft}$ in the Baxter Pond area to 3,000 ft near the headwaters of East Meadow Brook. The grid was most finely discretized in focus areas of active saltwater movement to eliminate a potential source of inaccuracy that may have affected sensitivity analysis as described in the "Model Sensitivity" section. 


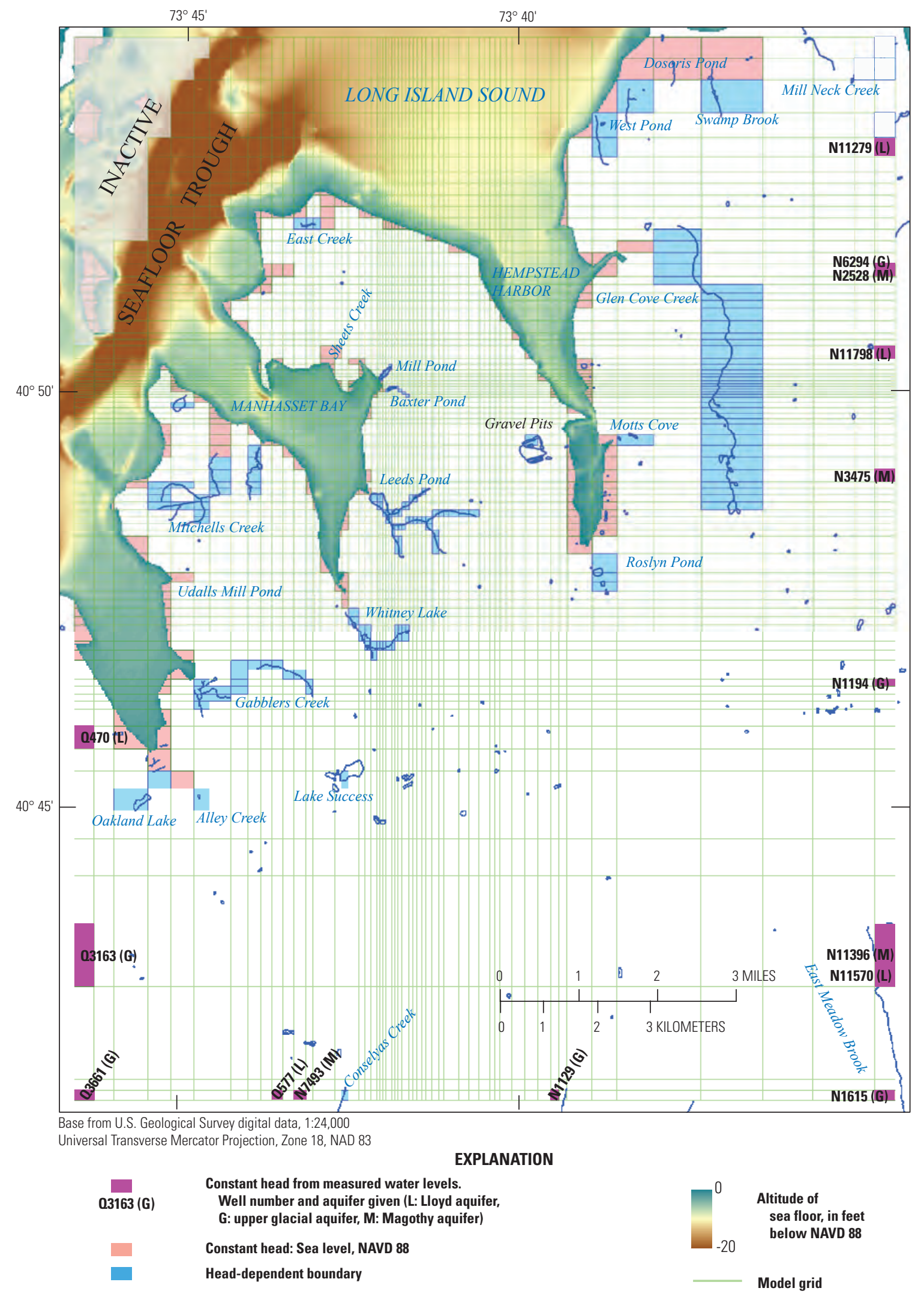

Figure 8. Model boundary conditions, Manhasset Neck, New York. 


\section{Model Design}

SEAWAT model enhancements to the previous generation SUTRA model (Monti and others, 2009), which simulated fully confined conditions, include (1) 20 percent greater model domain area, (2) greater number of stress periods, (3) head-dependent flow boundary representation of streams, (4) seasonal representation of recharge and pumping, and (5) longer total model simulation time. The SEAWAT model simulates both confined and unconfined conditions and, as such, simulates a moving water table with varying aquifer transmissivity dependent on simulated saturated thickness.

The 92-year, transient-state, historical simulation was divided into seasonal periods and was preceded by a 2 -stressperiod, 132-year simulation to generate a predevelopment initial head distribution, that did not include pumping and had constant recharge. This 2-stress-period, 132-year simulation is used to generate a steady-state initial condition for the subsequent transient simulation. The historical simulation began on January 1, 1920, ended on November 1, 2011, and contained 182 stress periods that represent seasonal conditions. The duration of 181 seasonal stress periods (out of 182) was 0.5 years, and 1 seasonal stress period (1/1/1920 to 4/1/1920) was 120 days in duration. The 2-period predevelopment simulation began November 1789 and ended January 1, 1920. A hypothetical future simulation from
November 1, 2011, to May 1, 2030, was conducted through repetition of stress periods 183 and 184 , corresponding to the year 2011. The model timeline is shown in figure 9 with areal recharge over the model domain and pumping at production well N1715, screened in the Lloyd aquifer (fig. 4), which may be susceptible to future saltwater intrusion. Stumm and others (2002) suggested that salinity (chloride concentration) variation at this well indicated preliminary signs of intrusion in the early 1990s.

Flows into and out of the eastern, western, and southern model boundaries were represented by constant head cells (fig. 8). Water-level measurements made for each stress period were averaged (fig. 10). Drought conditions during the middle to late 1960s are evident in the upper glacial and Magothy aquifer observation wells N3475, N2528, N1129, N7493, and to a lesser extent in Q470 and N11570, which are strongly affected by production-well pumpage in Queens County. Reduction of this pumpage in the 1980s is evident in the rebounding water levels in observation wells Q3163, N7493, Q470, and N11570. Decreased water levels in the summer (the peak water-demand season) are evident in the early records of observation wells N1615, Q470, and N11570 and the later records of most other wells as a result of the greater frequency of field water-level measurements. From about 1990 onward, most specified heads were calculated from measurements made during the corresponding stress period, whereas before

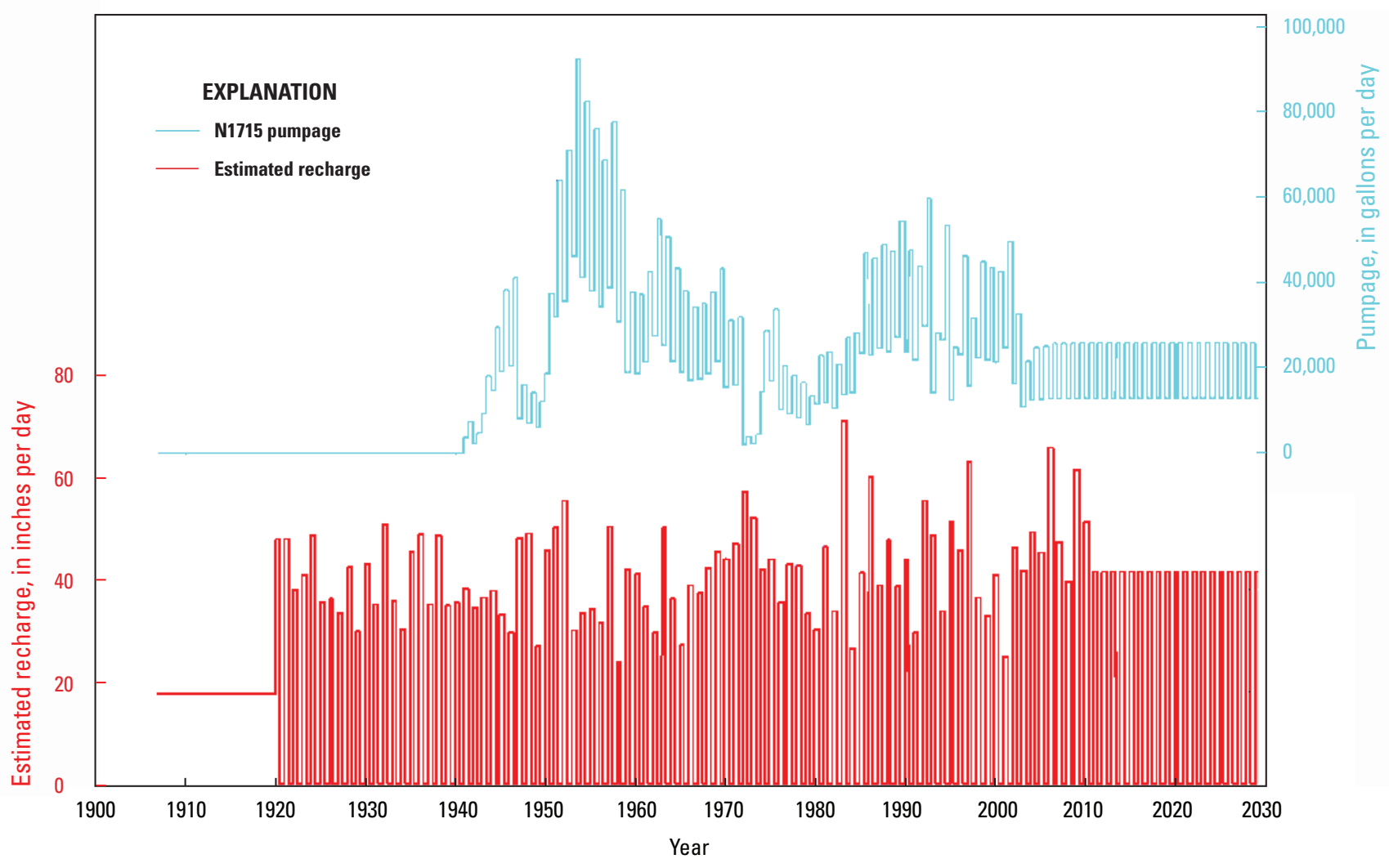

Figure 9. Estimated recharge and well N1715 pumpage, Manhasset Neck, New York, 1920-2030. 


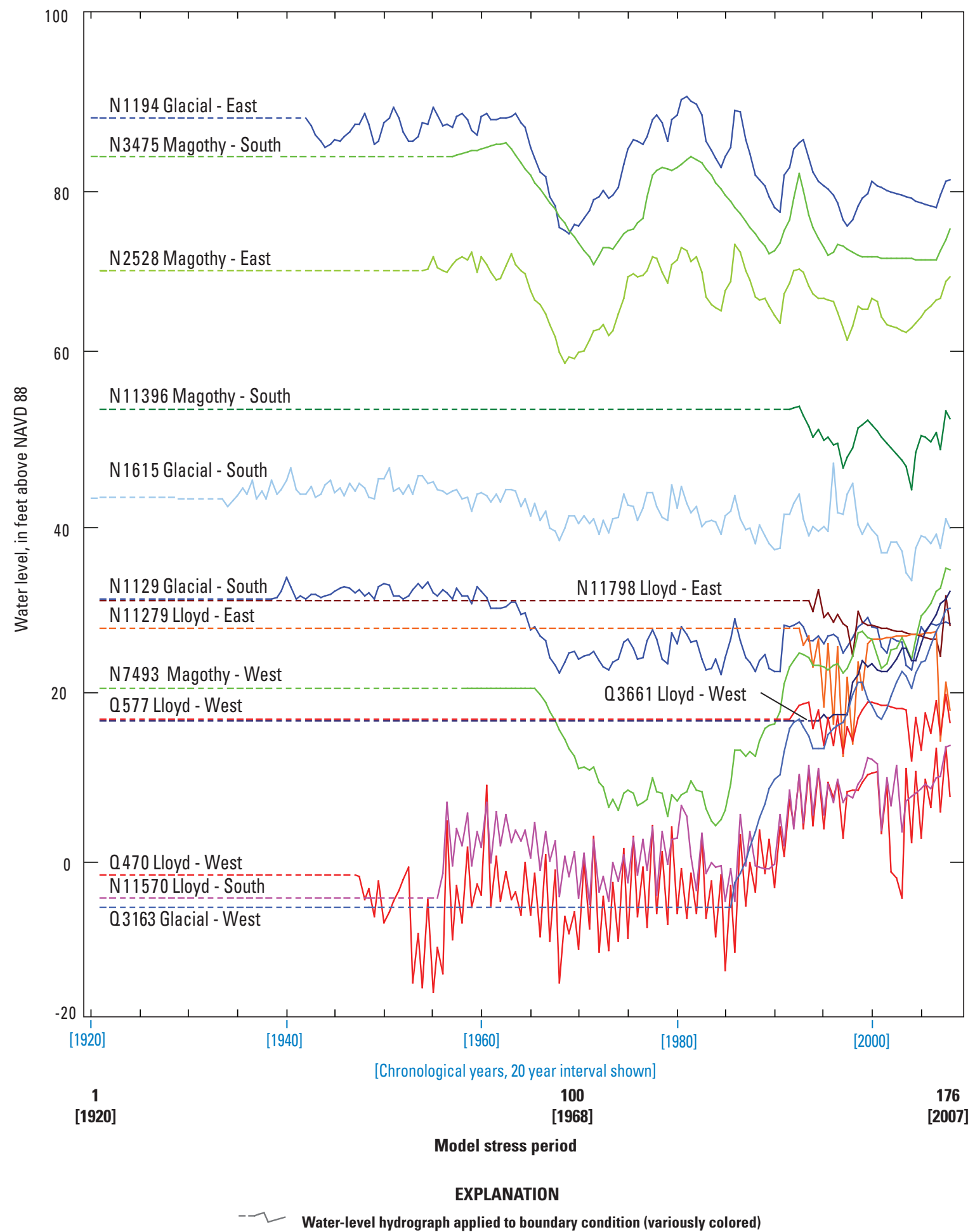

Figure 10. Water levels in observation wells at model boundaries, Manhasset Neck, New York. 
this time some heads were extrapolated from later waterlevel measurements.

Subsea discharge was represented by constant head boundaries along the seafloor in hydrostatic equilibrium with the sea level and was varied to represent historical sea-level rise from 1920 to 2011 (Horton and others, 2010). A constant salinity of 25 parts per 1,000 was specified at all sea-floor model cells (chloride concentration of $13850 \mathrm{mg} / \mathrm{L}$ ); thus modeled density of saline waters is uniformly 1.025 percent greater than modeled fresh water. Flow into and out of streams was represented by head-dependent flux boundaries using the MODFLOW DRAIN package (Harbaugh and others, 2000). For a drain cell, the volumetric flow rate is computed by using any set of consistent units as

$$
Q=C\left(h-h_{u}\right),
$$

where

$$
\begin{array}{ll}
Q & \text { is the flow rate across the streambed }\left(\mathrm{L}^{3} \mathrm{~T}^{-1}\right), \\
C & \text { is the conductance of the streambed }\left(\mathrm{L}^{2} \mathrm{~T}^{-1}\right), \\
h & \text { is the stream stage }(\mathrm{L}), \text { and } \\
h_{u} & \text { is the hydraulic head in the underlying cell }(\mathrm{L}) .
\end{array}
$$

The conductance of the streambed is given by

$$
C=K_{v} w L / m,
$$

where

$$
\begin{array}{ll}
K_{v} & \text { is the vertical hydraulic conductivity }\left(\mathrm{LT}^{-1}\right), \\
w & \text { is the width of the stream (L), } \\
L & \text { is the length of the stream (L), and } \\
m & \text { is the thickness of the streambed (L). }
\end{array}
$$

$K_{v}, w, L$, and $m$ were not individually specified; instead, conductance $C$ is initially specified at 1 square foot per day $\left(\mathrm{ft}^{2} / \mathrm{d}\right)$ and is subject to model calibration. $C$ and $h$ were assumed to be constant over time and were estimated through the use of digital-elevation models (fig. 1), water-table maps (Monti and Busciolano, 2009), and streamgage data, where available (fig. 3).

Production wells were represented as specified flux boundaries. Pumpage data typically were reported to the NYSDEC as annual totals. On the basis of inspection of monthly data, the annual pumpage data were apportioned as 66 percent for the peak-demand summer growing season (April 1 to October 1) and 34 percent for the off-peak winter season (October 1 to April 1). In non-sewered areas, nonconsumptive pumpage is returned to the aquifers through septic-system recharge augmentation. In the sewered areas, pumpage is not returned through septic-system recharge augmentation and is discharged to tidal waters from sewagetreatment plants. Sewered areas (http://www.nassaucountyny. gov/agencies/DPW/WasteWater.html, accessed April 24, 2013) are delineated as dark shaded areas of figure 2 and include Port Washington Business District, Manorhaven Village, and Hempstead Harbor Industrial Park.
The extent and thickness of hydrogeologic units (table 1) within the model were based on the previous groundwaterflow model (Monti and others, 2009) with multiple model layer representation of hydrogeologic units as follows: layer 1 , upper glacial aquifer; layers 2 and 3, upper glacial aquifer and North Shore confining unit; layers 4 to 7, Magothy aquifer and North Shore confining unit; layers 8 to 13, Raritan confining unit, North Shore aquifer, and North Shore confining unit; and layers 14 to 19, Lloyd aquifer, North Shore aquifer, and North Shore confining unit. Owing to an unconfined SEAWAT model requirement that the bottom of all cells be below sea level, the top three SUTRA model layers were combined into the top SEAWAT model layer. North to south (row) and east to west (column) slice-sequence animations of the hydrogeologic units of Monti and others (2009), as represented by the SEAWAT model, are shown in appendix 2.

\section{Model Calibration}

Simulated SEAWAT water levels (figs. 11A-C), flows (table 3), and salinities (fig. 12) generally matched SUTRA results shown in figures 8-10,14,16, and 18-23 of Monti and others (2009) when corresponding hydraulic parameters and boundary conditions were specified. Hydraulic parameters (horizontal and vertical hydraulic conductivity and specific storage) were initially set to the same values as Monti and others (2009). Discrepancies in the match of simulated to observed salinity (chloride concentration) in figure 12 include the following: (a) N12318, and (b) relation of N12793 to N12508). At well N12318 the freshwater/saltwater transition zone is simulated somewhat landward of what is expected from the measured field data, due to uncertainty concerning the size and shape of a breach in the overlying northshore confining unit that is infilled by upper glacial material (see fig. 9). This discrepancy suggests that the breach is of smaller area than as represented in the SUTRA ( Monti and others, 2009) and SEAWAT models, and perhaps may be shifted seaward. At wells N12793 and N12508, the transition zone is roughly in the same position in figure 12 whereas N12508 has considerably higher measured salinity (chloride concentration). Furthermore, figure 6 indicates that the screen zone of $\mathrm{N} 12793$ is over $100 \mathrm{ft}$ deeper than N12508. This discrepancy of figure 12 may be due to several factors: the latest available data for $\mathrm{N} 12793$ is 4 years older than N12508, and the proximity of N12508 to the boundary between the Lloyd and North Shore aquifers. Although N12508 is represented in SUTRA (Monti and others, 2009) and SEAWAT models as located within the Lloyd aquifer, it is possible that locally, hydraulic conditions near N12508 may be better approximated with North shore aquifer parameters which promote the landward movement of the freshwater/ saltwater transition zone in response to stress.

With SEAWAT model enhancements and an increased number of calibration match points, the goal was to improve statistical measures of fit and to achieve greater accuracy 
$\boldsymbol{A}$ $73^{\circ} 45^{\prime}$

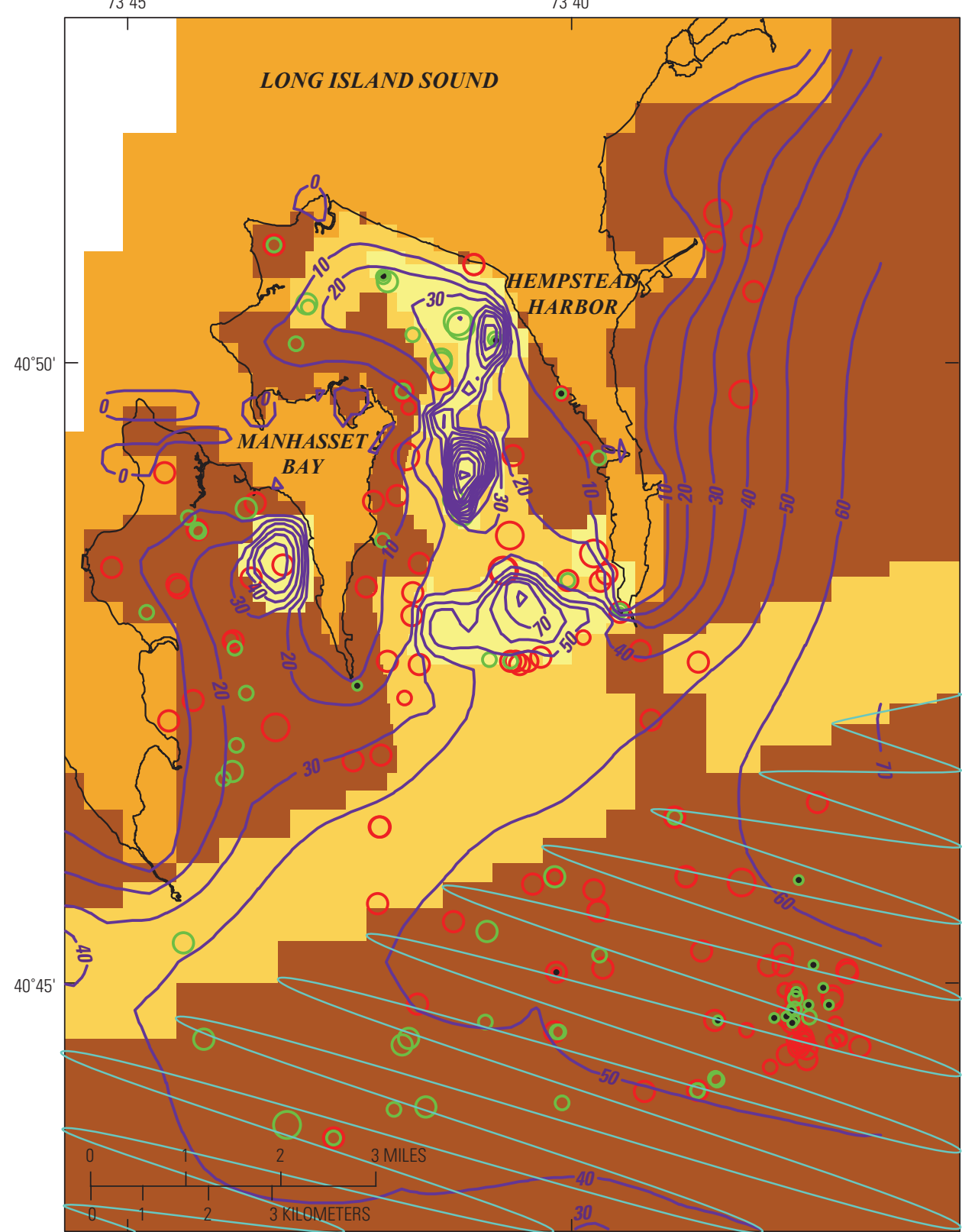

Base from U.S. Geological Survey digital data, 1:24,000

Universal Transverse Mercator Projection, Zone 18, NAD 83

Simulated head minus observed head, feet

( -8.0 to $<-5.0$

- 0.0001 to $<0.0006$

-5.0 to $<-2.0 \quad 0.0006$ to $<0.5$

-2.0 to $<-0.5 \bigcirc 0.5$ to $<5.0$

-0.5 to $<0 \bigcirc 5.0$ to $<10.0$

EXPLANATION

Vertical hydraulic conductivity, in feet per day. Based on Monti and others, 2009

Area where water table is present within Magothy aquifer

$-10-\begin{gathered}\text { Simulated water level, in feet above NAVD } 88 . \\ \text { Interval is } 10 \text { feet }\end{gathered}$
-

Figure 11. Vertical hydraulic conductivity and simulated water-level contours in the $A$, upper glacial aquifer, $B$, Magothy aquifer, and $C$, North Shore/Lloyd aquifers Manhasset Neck, New York, 2007. 
B

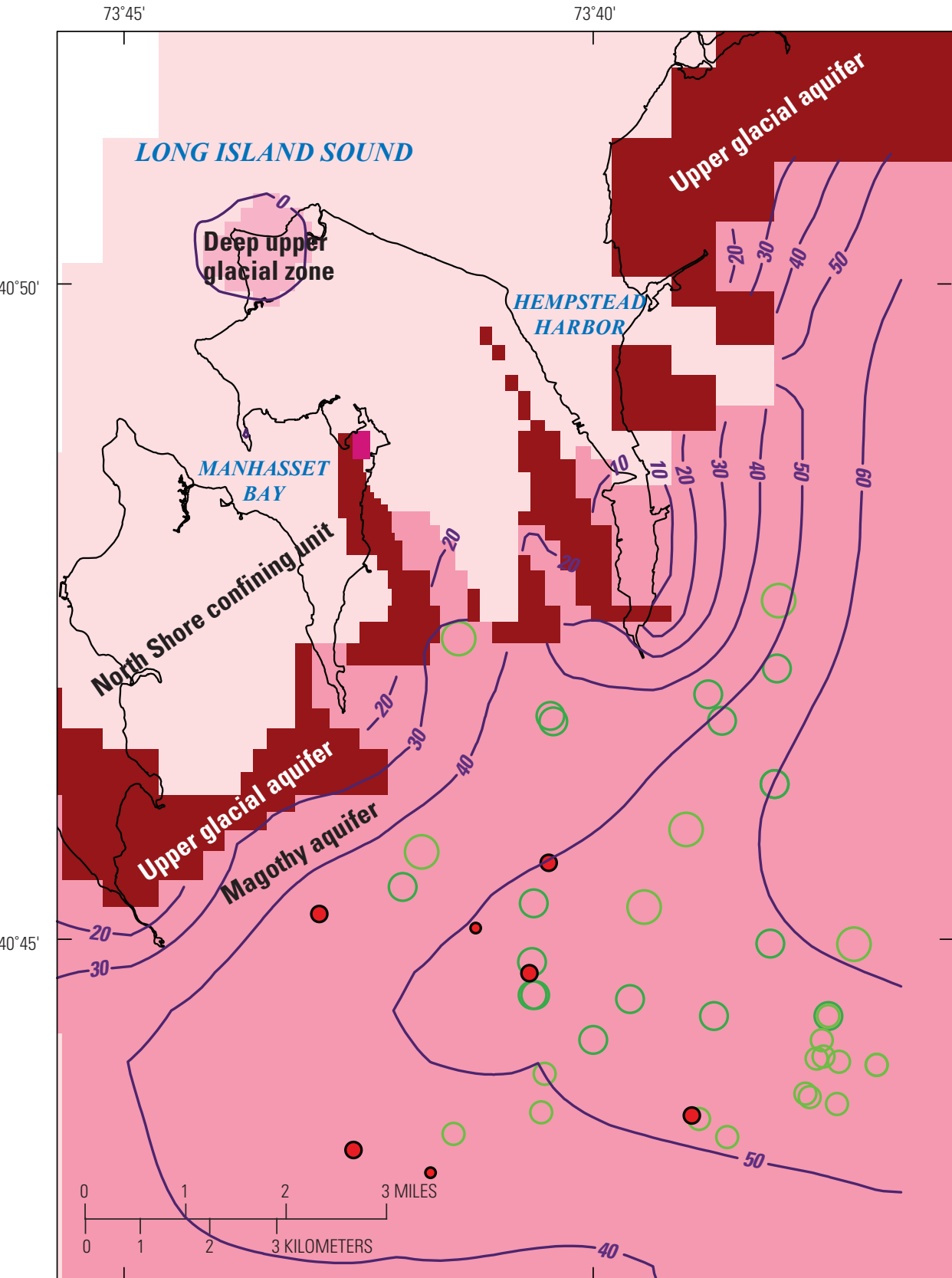

Base from U.S. Geological Survey digital data, 1:24,000

Universal Transverse Mercator Projection, Zone 18, NAD 83

Simulated minus observed, feet

EXPLANATION

$\bullet \quad<-5.9$

- -5.9 to $<-3.2$

-3.2 to $<0$

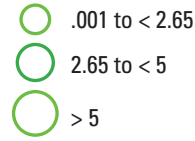

Vertical hydraulic conductivity, in feet per day. Based on Monti and others, 2009

$<0.000030$

0.000031 to $<0.000245$

0.000245 to $<0.152400$

0.152400 to $<0.609600$

0.609600 to $<1.828800$

- 10- Simulated water level, in feet above NAVD 88. Interval is 10 feet

Figure 11. Maps showing vertical hydraulic conductivity and simulated water-level contours in the $A$, upper glacial aquifer, $B$, Magothy aquifer, and $C$, North Shore/Lloyd aquifers Manhasset Neck, New York, 2007. 
C $73^{\circ} 45^{\prime}$

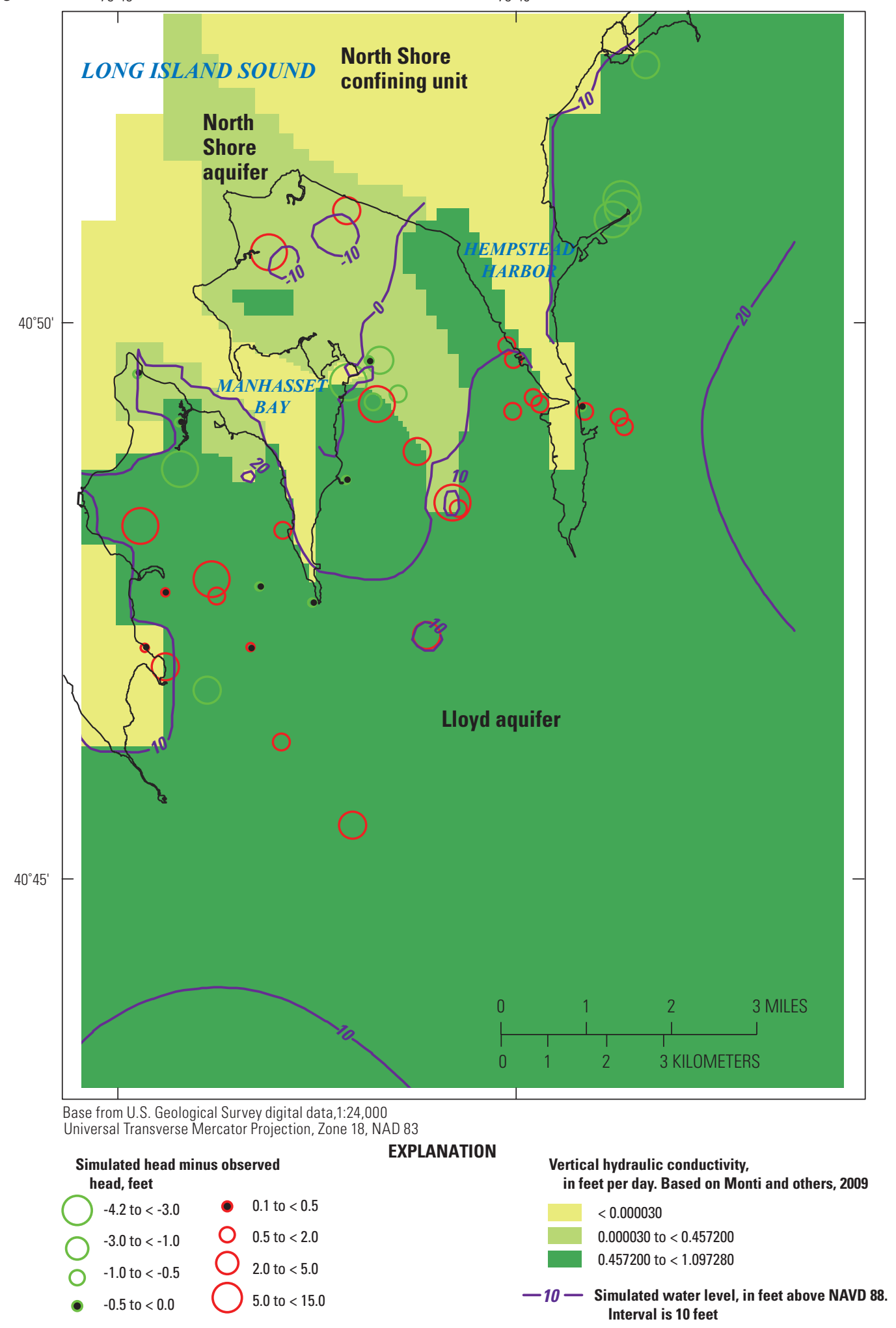

Figure 11. Maps showing vertical hydraulic conductivity and simulated water-level contours in the $A$, upper glacial aquifer, $B$, Magothy aquifer, and $C$, North Shore/Lloyd aquifers Manhasset Neck, New York, 2007. 
Table 3. Water budgets for three periods from the SEAWAT model, Manhasset Neck, New York.

[Units in million cubic feet per day. Negative values indicate water leaving the model]

\begin{tabular}{|c|c|c|c|}
\hline Location & Predevelopment period & 2007 summer period & 2007 winter period \\
\hline \multicolumn{4}{|c|}{ Onshore } \\
\hline Recharge (precipitation) & 29.6 & 6.6 & 29.6 \\
\hline Eastern lateral boundary & -1.7 & 3.9 & 1.8 \\
\hline Western lateral boundary & -2.0 & 1.9 & -1.0 \\
\hline Wells (pumpage) & 0 & -4.2 & -2.2 \\
\hline Stream discharge & -1.4 & -0.3 & -0.5 \\
\hline \multicolumn{4}{|c|}{ Offshore (subsea discharge) } \\
\hline Little Neck & -2.8 & -1.3 & $\begin{array}{l}-1.9 \\
-1.9 \\
-4.2 \\
-1.7\end{array}$ \\
\hline Hempstead Harbor & -6.4 & -3.2 & \\
\hline Long Island Sound & -2.4 & -1.1 & \\
\hline
\end{tabular}

in parameter estimates than was possible with the SUTRA model. An increase in the number of calibration points is due mainly to enhanced representation of the time series but is due also to the larger model area and the longer historical calibration record. SUTRA parameter values were retained for most aquifers and confining units if the use of those values resulted in a reasonable calibration; these included specific yield of 0.2 and specific storage of 5 e-5. Other parameters were constrained to ranges between 0.1 and 200 percent of SUTRA values during an automated parameter estimation process using the Parameter ESTimation PEST software (Doherty and Johnston, 2003) with simulations conducted in a confined configuration to prevent numerical instability. PEST estimation was conducted by using head measurement data only (not salinities and flows). Estimated zones of vertical hydraulic conductivity included those of the upper glacial aquifer and the Raritan confining unit. Several zones of the model representing the upper glacial aquifer (offshore, moraine 1 to 5, outwash, and basal, fig. 11) were adjusted in size and shape, and the new "alternative model conceptualization" of Monti and others (2009) with upper glacial sediments running under part of Manhasset Bay was generally adopted. Calibration statistics and model results were then generated with a final unconfined SEAWAT model run after PEST parameter estimation was complete. The fit of the calibration was assessed according to the agreement between the water levels in the target wells and the modelcalculated water levels at the locations of these wells through use of a comparison of residual mean and root mean squared error (RMSE) values (table 4) with those of the SUTRA model. Hydraulic conductivity values were generally lesser in the calibrated SEAWAT model than in the SUTRA model (table 5).

Simulated SEAWAT water levels (fig. 13 shows representative hydrographs) demonstrate the effects of seasonal changes in recharge and pumping, yearly changes in pumping, and changes in flows into and out of model's eastern, southern, and western boundaries. Drought during the middle to late 1960s affected water levels in wells under unconfined conditions. Water levels in deeper confined wells showed a greater effect from pumping and did not respond to the drought condition as dramatically as those in shallower wells. This may be demonstrated by comparison of observation well N11570, a deep Lloyd well, subdued drought response with observation well N1194, a shallow upper glacial to the north, dramatic drought response (locations shown in fig. 8, hydrographs shown in fig. 10).

\section{Groundwater Flowpaths}

The sources to production wells in 2007 were analyzed by using the MODPATH6 particle-tracking method (Pollock, 2012). Particles were initiated in a circular pattern around wells and the groundwater flowpath tracked backward through the model simulation towards points of origin in the groundwater-flow system, generally orthogonal to the simulated water-level contour lines shown in figure 11 . All particles either originate as groundwater recharge at the top surface of the model or remain active within the 


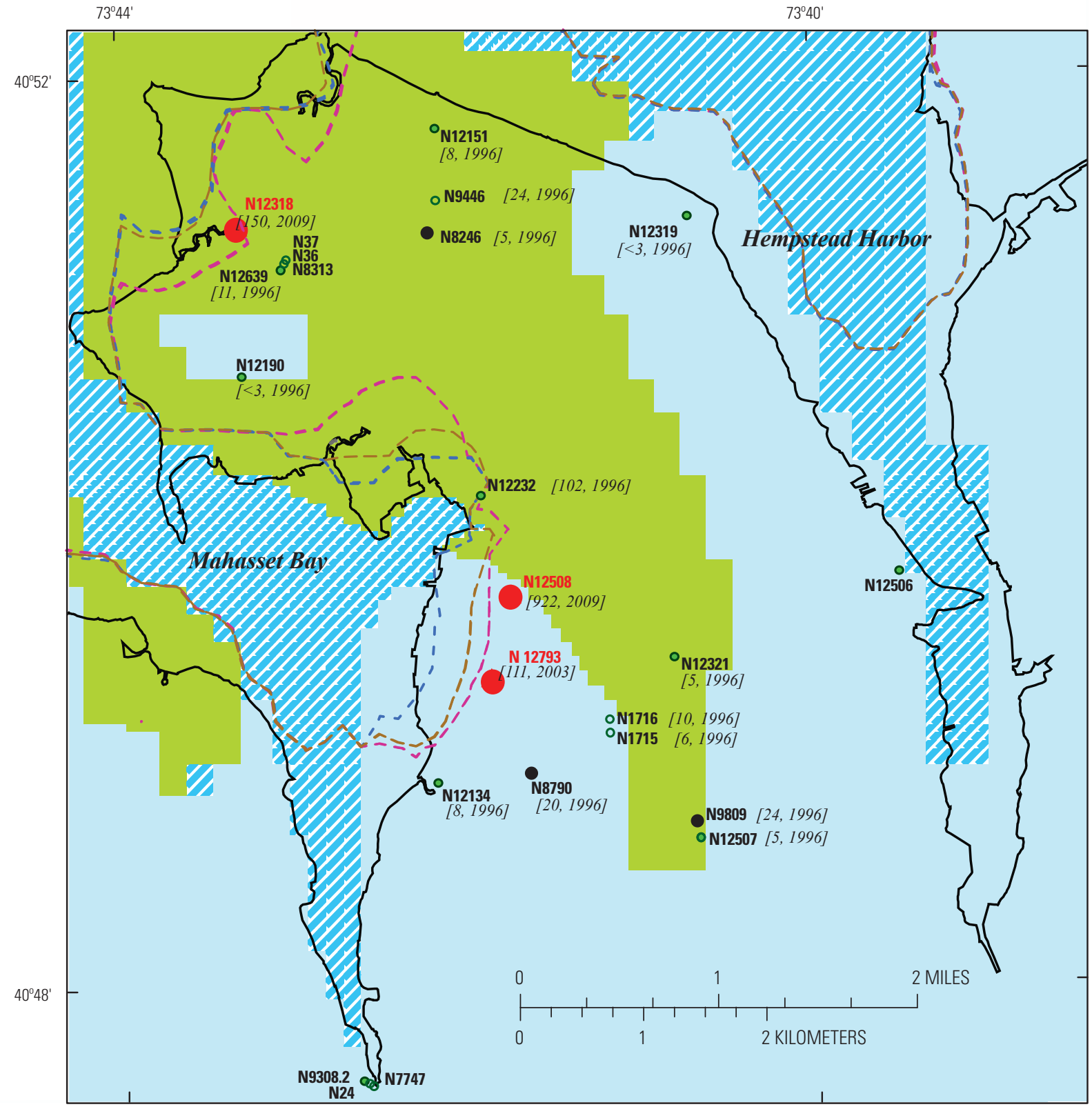

Base from U.S. Geological Survey digital data, 1:24,000

Universal Transverse Mercator Projection, Zone 18, NAD 83

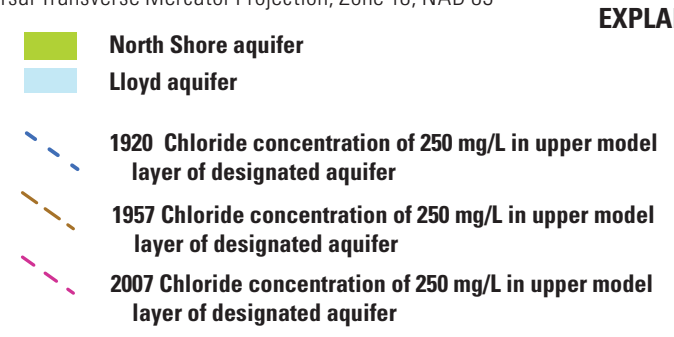

EXPLANATION

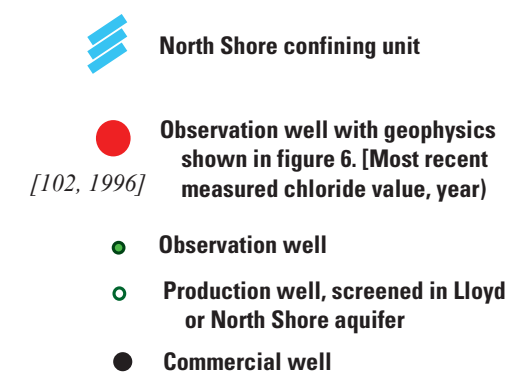

Figure 12. Simulated saline-groundwater contours in Lloyd and North Shore aquifers, Manhasset Neck, New York, 1920-2007. (mg/L, milligrams per liter) 
Table 4. Calibration statistics for water levels from the SEAWAT and SUTRA models for Manhasset Neck, New York.

[Values are in feet. M, residual mean; RMSE, root mean square error; n, number of measurements]

\begin{tabular}{lcccccccc}
\hline \multirow{2}{*}{ Hydrogeologic unit } & \multicolumn{3}{c}{ SEAWAT model } & & \multicolumn{3}{c}{ SUTRA model } \\
\cline { 2 - 4 } \cline { 6 - 8 } & $\mathbf{M}$ & RMSE & $\mathbf{n}$ & & $\mathbf{M}$ & RMSE & $\mathbf{n}$ \\
\hline Upper glacial aquifer & 1.6 & 8.1 & 10,549 & & 13.3 & 25.6 & 64 \\
North Shore aquifer & 3.1 & 8.3 & 1,088 & & 3.7 & 5.5 & 19 \\
Magothy aquifer & 1.5 & 7.3 & 2,248 & & -0.1 & 7.1 & 20 \\
Lloyd aquifer & -1.1 & 7.0 & 2,041 & & 1.8 & 5.2 & 30 \\
Total & 1.3 & 7.88 & 15,926 & & 7.3 & 18.2 & 133 \\
\hline
\end{tabular}

Table 5. Horizontal and vertical hydraulic conductivity of aquifers and confining units simulated using the SEAWAT and SUTRA models of Manhasset Neck, New York.

[Hydraulic conductivity values are in feet per day]

\begin{tabular}{lcccc}
\hline \multirow{2}{*}{ Hydrogeologic unit } & \multicolumn{3}{c}{ SEAWAT model } & \multicolumn{2}{c}{ SUTRA model } \\
\cline { 2 - 4 } \cline { 2 - 4 } & Horizontal & Vertical & Horizontal & Vertical \\
\cline { 2 - 4 } Upper glacial aquifer & & & & \\
Offshore & 100 & 25 & 100 & 25 \\
North Shore & 50 & 15 & 100 & 30 \\
Moraine 1 & 30 & 0.3 & 30 & 0.3 \\
Moraine 2 & 5 & 0.05 & 20 & 0.2 \\
Moraine 3 & 5 & 0.05 & 5 & 0.005 \\
Moraine 4 & 0.1 & 0.0001 & 1 & 0.001 \\
Moraine 5 & 0.1 & 0.001 & 5 & 0.05 \\
Outwash & 250 & 25 & 270 & 27 \\
Basal & 75 & 7.5 & 100 & 25 \\
North Shore confining unit & 0.01 & 0.0015 & 0.01 & 0.0015 \\
Upper Magothy aquifer & 40 & 0.5 & 40 & 0.5 \\
Lower Magothy aquifer & 80 & 0.6 & 80 & 0.6 \\
Raritan confining unit & 0.007 & 0.001 & 0.01 & 0.0012 \\
North Shore aquifer & 15 & 1.5 & 15 & 1.5 \\
Lloyd aquifer & 40 & 4 & 40 & 4 \\
\hline
\end{tabular}



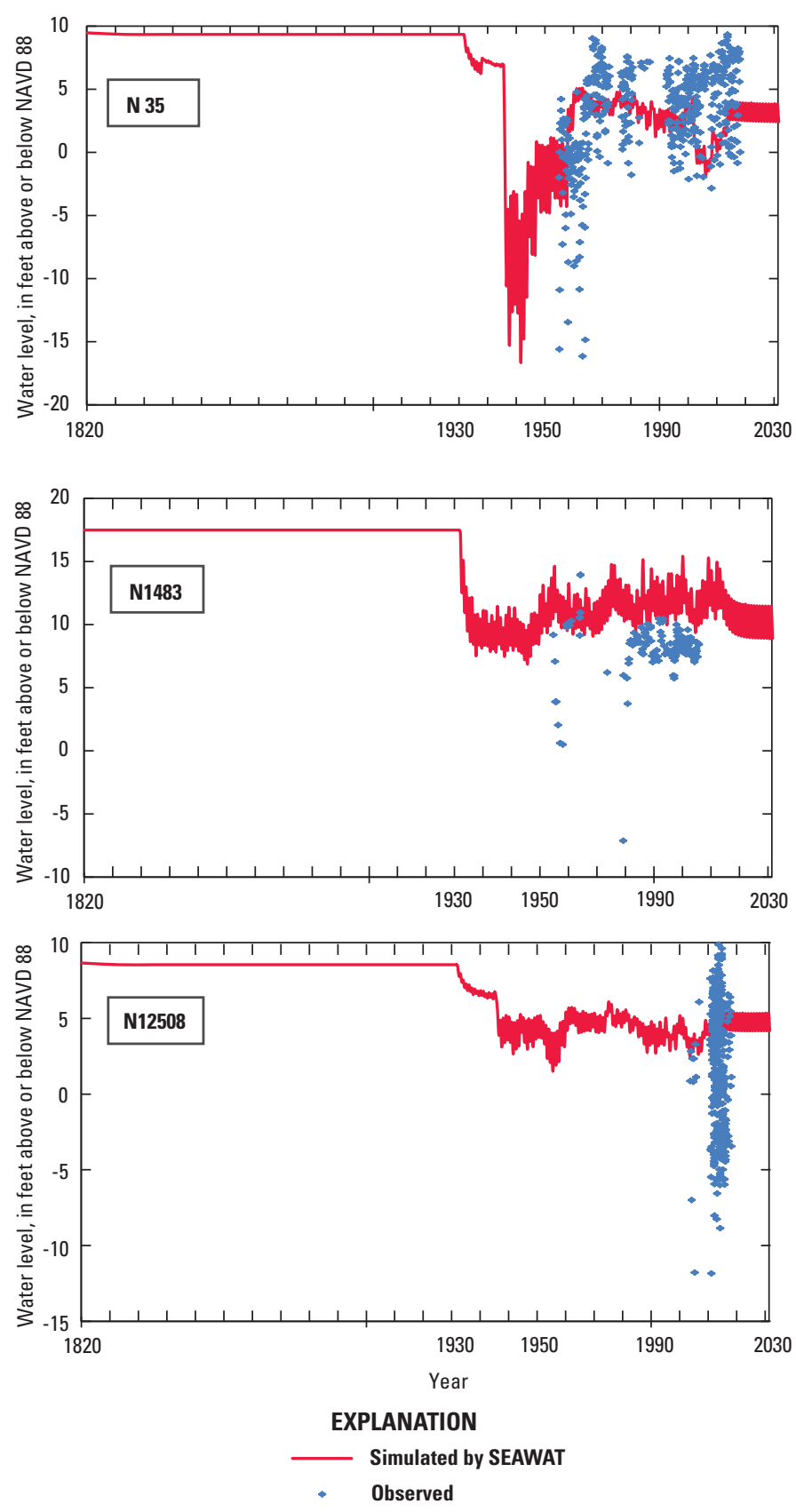

Figure 13. Simulated and observed water levels in selected wells, Manhasset Neck, New York, 1930-2030.

groundwater system throughout the entire model simulation (fig. 14). Particles that remain active indicate that pumping captures groundwater which recharged the system prior to 1920; the maximum flowpath duration analyzed in this study is 100 years. Some groundwater on Long Island may be expected to exceed several thousands of years in age (Misut and Feldman, 1996). Groundwater flowpath travel times are directly related to specified effective porosity values, which were set to 20 percent for all aquifers in the SEAWAT and MODPATH6 models (within the range given by Freeze and
Cherry, 1979).When particles travel near a pumped well or other point of model discharge, deflection of the particle path toward that well typically occurs. This may introduce errors into flowpath delineation if the particle is allowed to be technically captured (theoretically, particles should terminate at points of recharge, not discharge). When particles cross hydrogeologic units, changes in hydraulic properties typically result in a change in velocity and diffraction of the flowpath; for example, particles typically travel in a more vertically oriented direction through confining units than through aquifers.

Production wells south of Route $25 \mathrm{~A}$ are screened within the Magothy aquifer (figs. 2 and 14) and are subjected to particle-tracking analysis. The general location of these wells, are N7551, N7552, and N15310 at Christopher Morley Park (fig. 14A); N8010 and N5528 at Roslyn Estates (fig. 14A); N8564 at Lake Success (fig. 14B); N7512 at North New Hyde Park ( fig. 14B); and N9309 at Strathmore (fig. 14C). Groundwater flowpaths associated with these wells generally flow towards each pumped well in a southeast-to-northwest direction. Christopher Morley Park production wells N7551, N7552, N15310 are screened in the Magothy aquifer and mainly capture deep groundwater originating beneath Albertson, Westbury, and Old Westbury along relatively long and smooth flowpaths that do not appear to be strongly affected by interference from other stresses. These wells may capture some shallow groundwater recharged from points several thousand feet south of the park. Production well N7551 demonstrates a radially converging flow pattern near the well. Roslyn Estates production well N8010 is screened in the Magothy aquifer and captures deep water originating beneath Albertson and Old Westbury; the simulated particles started at this well follow similar flowpaths as those associated with the Christopher Morley Park wells. At the bottom of its screened interval in the Magothy aquifer, Roslyn Estates production well N5528 captures some groundwater originating as recharge near Christopher Morley Park. At the top of its screened interval, Roslyn Estates production well N5528 may also capture some shallow groundwater recharged from points several hundred feet to the southeast. At the bottom of its screened interval in the Magothy aquifer, North New Hyde Park production well N7512 (fig. 14B) captures deep groundwater originating as far away as Manhasset Hills and demonstrates a radial flow pattern near the well. At the top of its screened interval in the Magothy aquifer, well N7512 may also capture some shallow groundwater recharged from points several thousand feet to the east. At the bottom of its screened interval in the Magothy aquifer, Lake Success production well N8564 captures groundwater originating as far away as Manhasset Hills and demonstrates a seasonally moderated radial pattern near the well. At the top of its screened interval in the Magothy aquifer, production well N8564 may also capture some shallow groundwater recharged from points several thousand feet to the southeast near the Long Island Expressway. Strathmore production well N9309 (fig. 14C), screened in the Lloyd aquifer, captures deep 


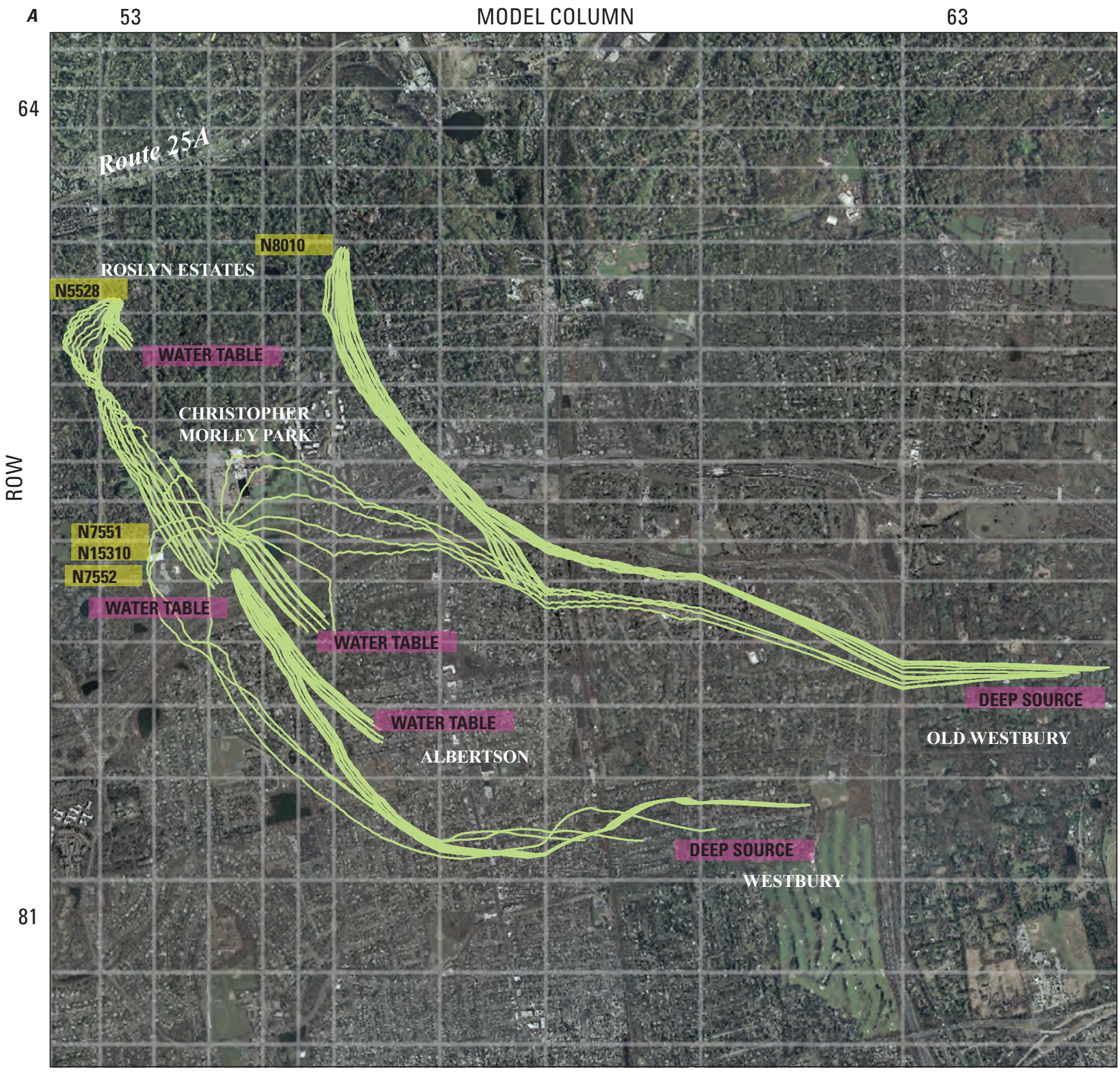

Base from New York State Digital Orthoimagery Program (2011) Universal Transverse Mercator Projection, Zone 18, NAD 83
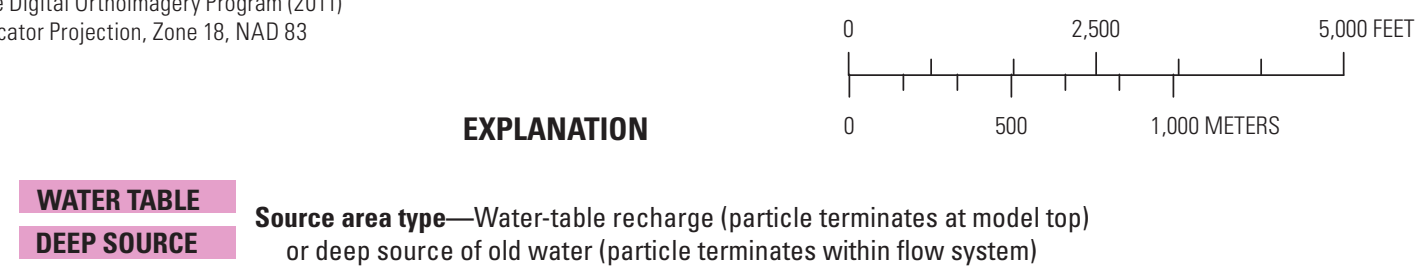

N8564 Particle start location at production well—Backtracking mode

Simulated groundwater flowpath-Maximum travel time, 100 years.

Pathlines originate in Magothy aquifer

Figure 14. Simulated particle pathlines from the water table or deep sources to selected production wells in $A$, Christopher Morley Park and Roslyn Estates, B, Lake Success and North New Hyde Park, $C$, Strathmore and Flower Hill, D, Port Washington, and $E$, Baxter Estates, Round Hill/Tibbets Lane, Governors Lane, Village Club, and, Sands Point Golf Club, Manhasset Neck, New York, 2007. 
$B$ 38 MODEL COLUMN

57

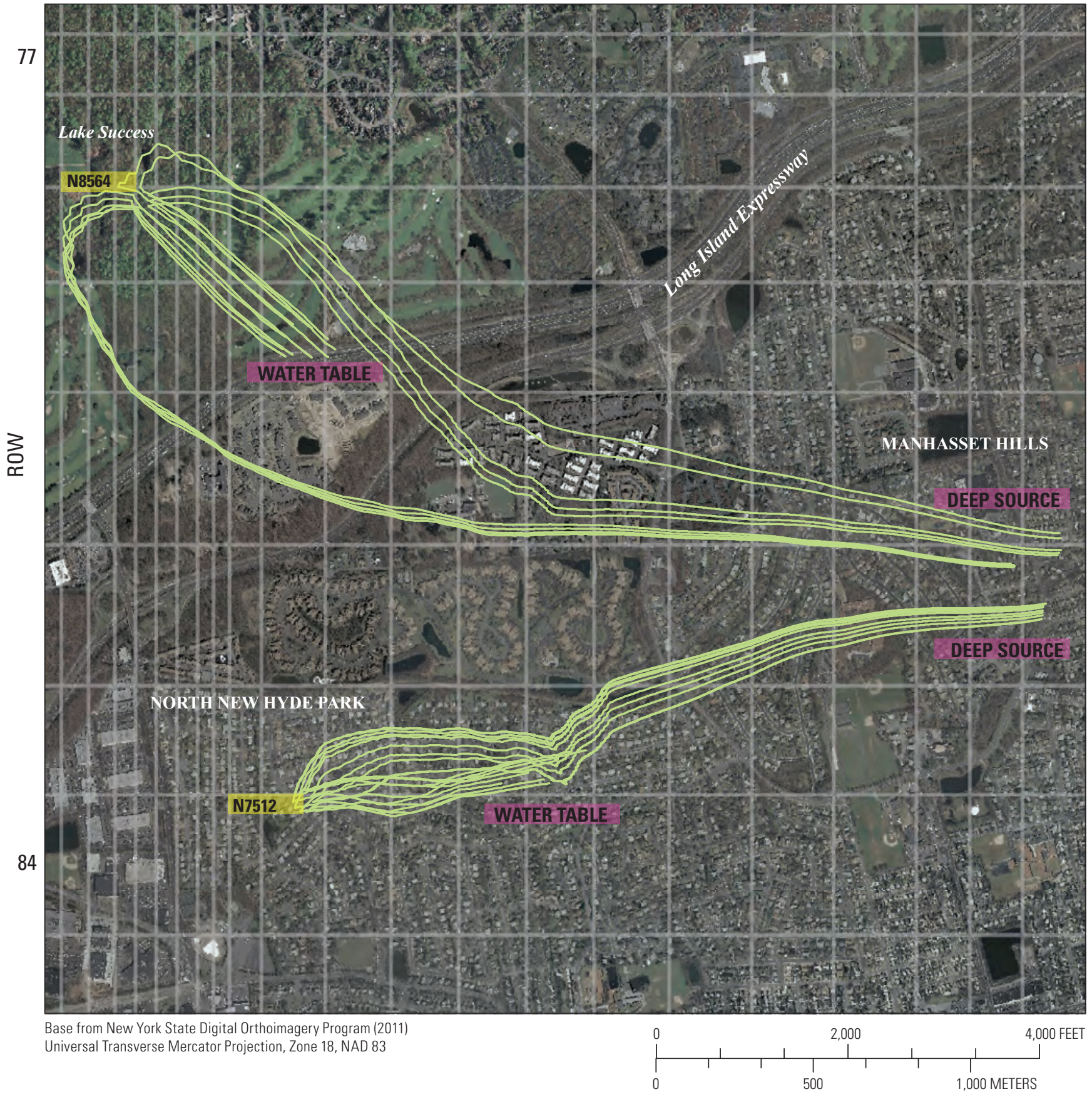

EXPLANATION

WATER TABLE Source area type-Water-table recharge (particle terminates at model top)
DEEP SOURCE
or deep source of old water (particle terminates within flow system)

N8564 Particle start location at production well-Backtracking mode

Simulated groundwater flowpath-Maximum travel time, 100 years.

Pathlines originate in Magothy aquifer

Figure 14. Maps showing simulated particle pathlines from the water table or deep sources to selected production wells in A, Christopher Morley Park and Roslyn Estates, B, Lake Success and North New Hyde Park, C, Strathmore and Flower Hill, $D$, Port Washington, and E, Baxter Estates, Round Hill/Tibbets Lane, Governors Lane, Village Club, and, Sands Point Golf Club, Manhasset Neck, New York, 2007. 
C

60

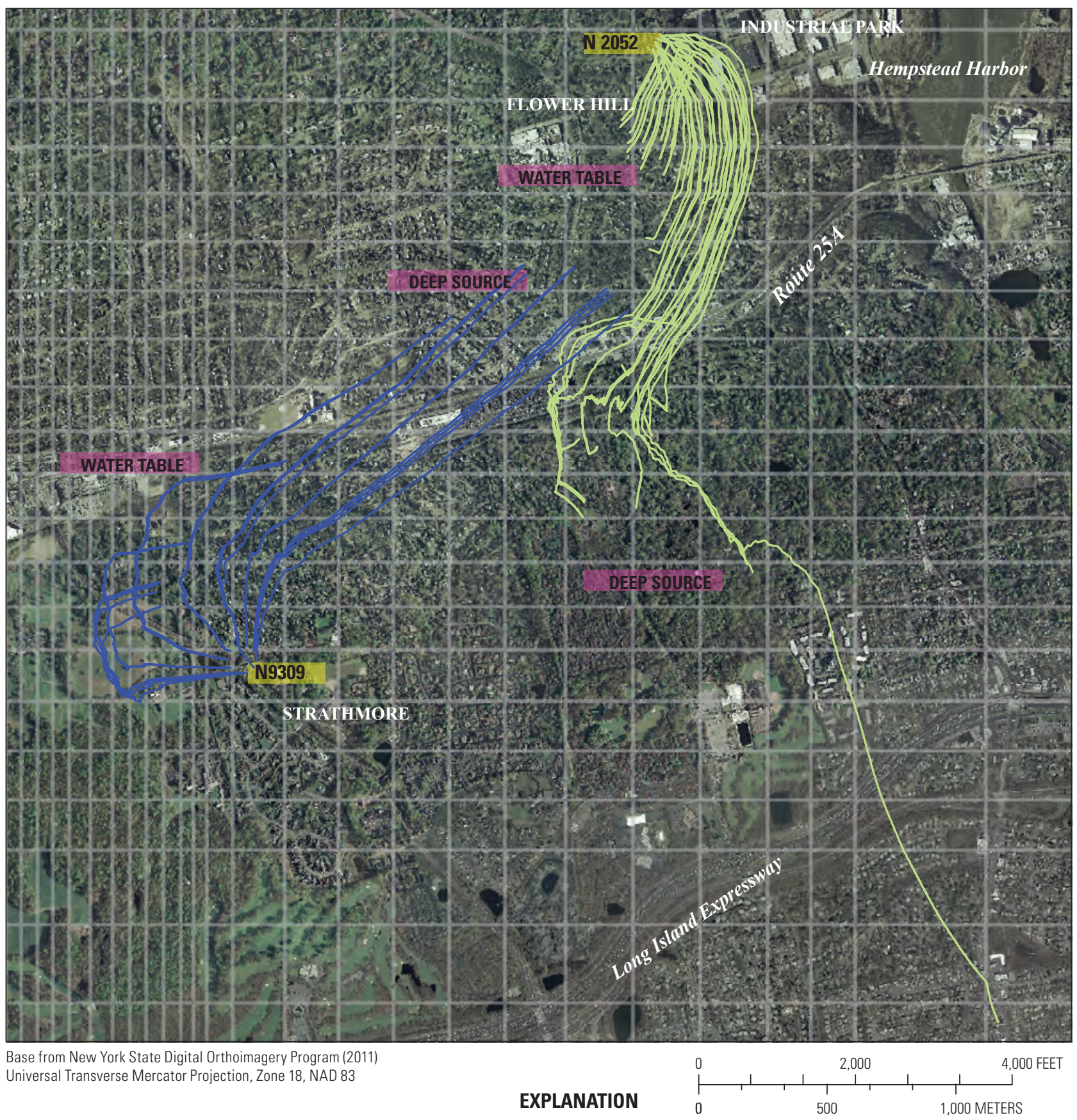

WATER TABLE Source area type-Water-table recharge (particle terminates at model top)

DEEP SOURCE or deep source of old water (particle terminates within flow system)

N9309 Particle start location at production well—Backtracking mode

Simulated groundwater flowpath-Maximum travel time, 100 years

Pathlines originate in Magothy aquifer

Pathlines originate in Lloyd aquifer

Figure 14. Maps showing simulated particle pathlines from the water table or deep sources to selected production wells in $A$, Christopher Morley Park and Roslyn Estates, B, Lake Success and North New Hyde Park, C, Strathmore and Flower Hill, $D$, Port Washington, and E, Baxter Estates, Round Hill/Tibbets Lane, Governors Lane, Village Club, and, Sands Point Golf Club, Manhasset Neck, New York, 2007.—continued 
D 21 MODEL COLUMN 60

45

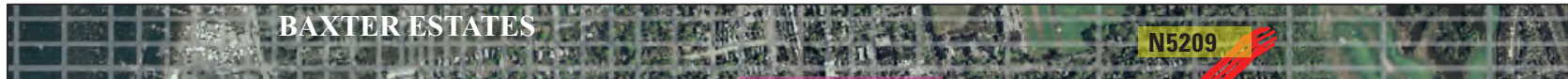
YACHT CLUB

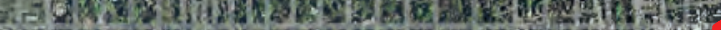

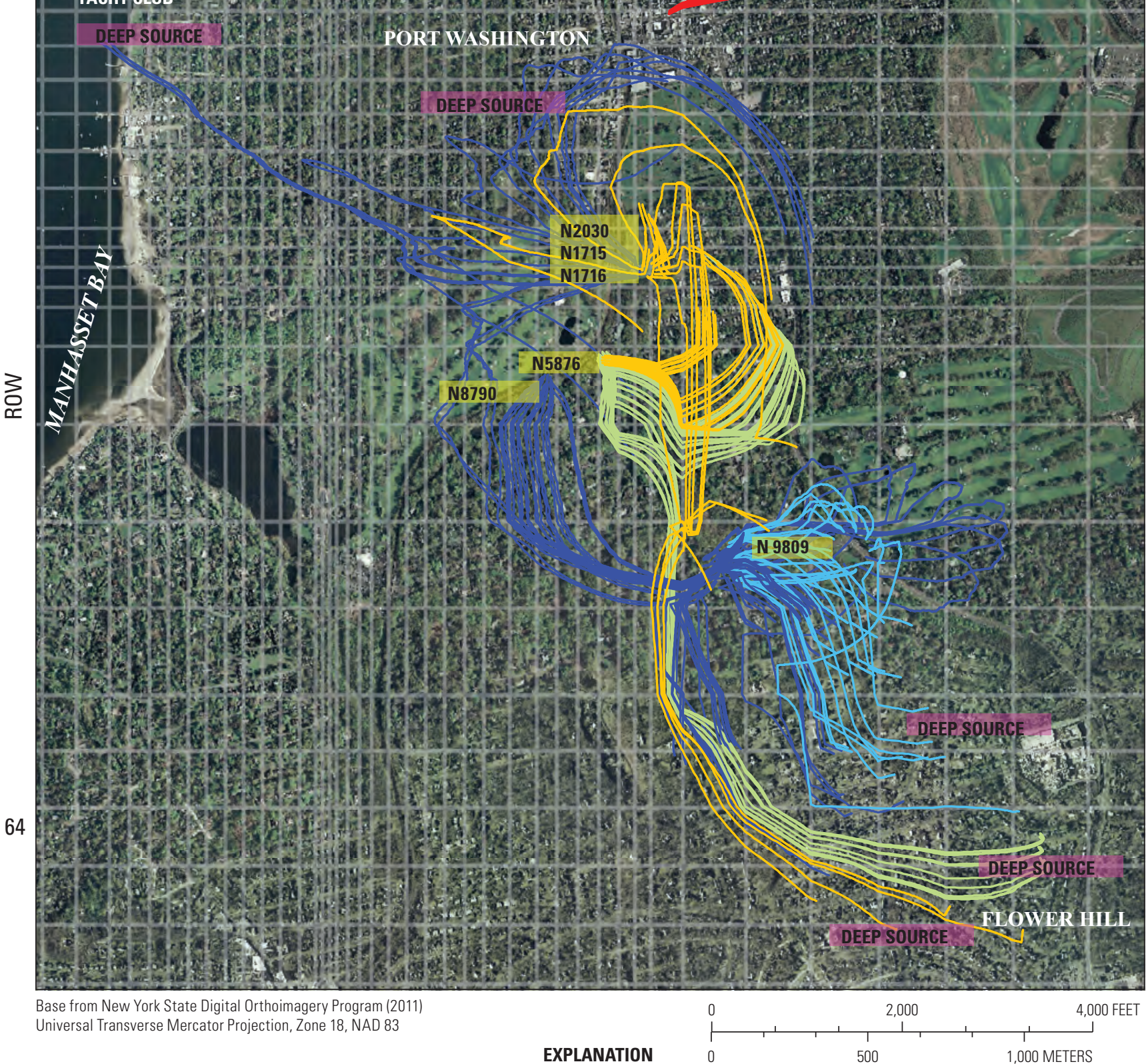

\begin{tabular}{|c|c|}
\hline \multirow{2}{*}{$\begin{array}{l}\text { WATER TABLE } \\
\text { DEEP SOURCE }\end{array}$} & $\begin{array}{l}\text { Source area type-Water-table recharge (particle terminates at model } \\
\text { or deep source of old water (particle terminates within flow system) }\end{array}$ \\
\hline & \\
\hline N8790 & Particle start location at production well—Backtracking mode \\
\hline & Simulated groundwater flowpath—Maximum travel time, 100 years. \\
\hline & $\begin{array}{l}\text { Pathlines originate in lower zone of Upper Glacial aquifer } \\
\text { Pathlines originate in Lloyd aquifer } \\
\text { Pathlines originate in the Upper Glacial aquifer } \\
\text { Pathlines originate in the North Shore aquifer }\end{array}$ \\
\hline
\end{tabular}

Figure 14. Simulated particle pathlines from the water table or deep sources to selected production wells in $A$, Christopher Morley Park and Roslyn Estates, B, Lake Success and North New Hyde Park, C, Strathmore and Flower Hill, D, Port Washington, and E, Baxter Estates, Round Hill/Tibbets Lane, Governors Lane, Village Club, and, Sands Point Golf Club, Manhasset Neck, New York, 2007. 
$E$ MODEL COLUMN

54

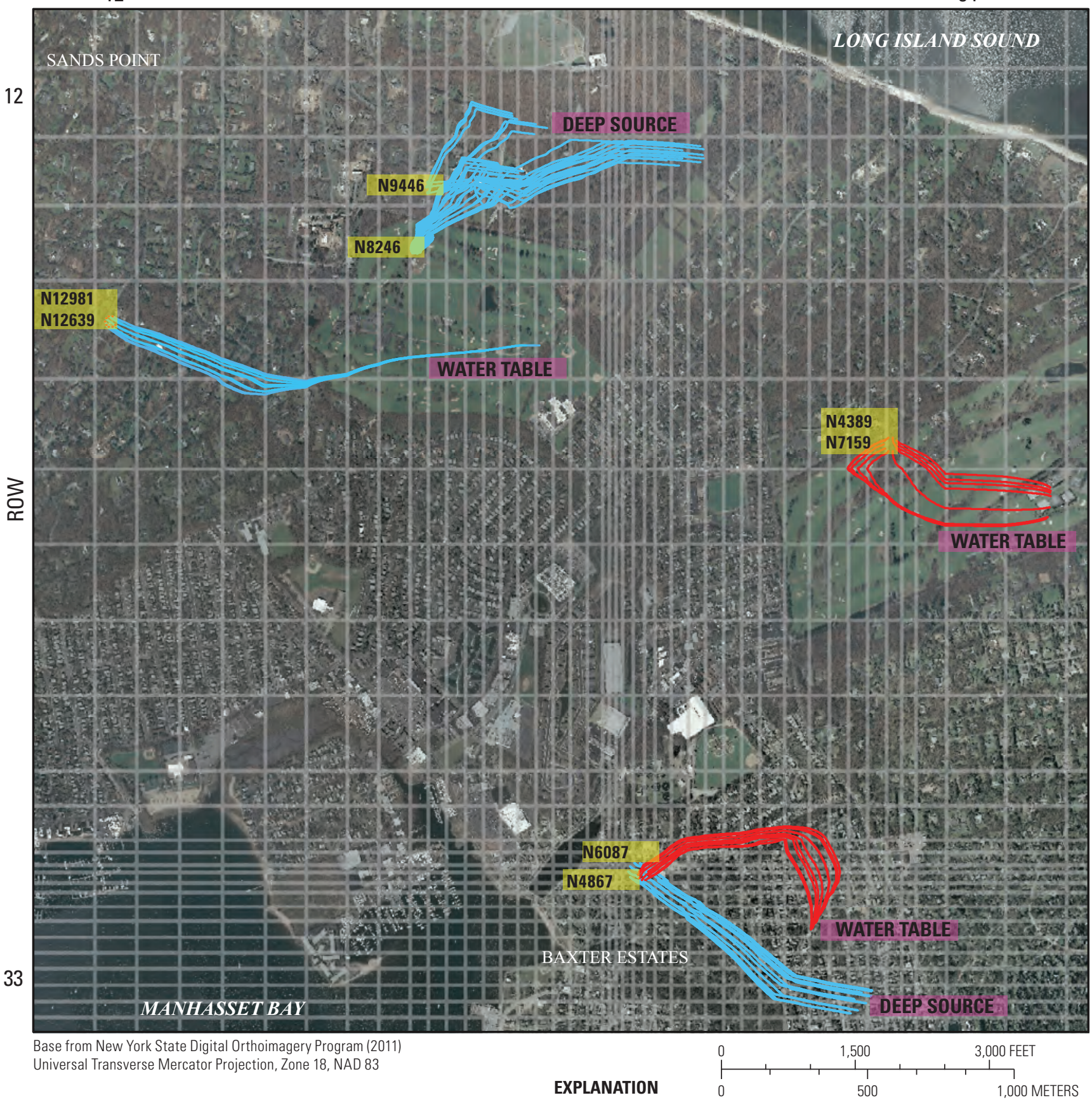

WATER TABLE Source area type-Water-table recharge (particle terminates at model top)

DEEP SOURCE or deep source of old water (particle terminates within flow system)

N9446 Particle start location at production well-Backtracking mode

Simulated groundwater flowpath-Maximum travel time, 100 years

Pathlines originating in upper glacial aquifer

Pathlines originating in North Shore aquifer

Figure 14. Simulated particle pathlines from the water table or deep sources to selected production wells in $A$, Christopher Morley Park and Roslyn Estates, B, Lake Success and North New Hyde Park, C, Strathmore and Flower Hill, D, Port Washington, and E, Baxter Estates, Round Hill/Tibbets Lane, Governors Lane, Village Club, and, Sands Point Golf Club, Manhasset Neck, New York, 2007. 
groundwater originating in Flower Hill to the northeast and demonstrates some radial convergence. Although deep-water flow within the Lloyd aquifer associated with production well N9309 is generally northeast to southwest, flow is in the opposite direction, from southwest to northeast, in the upper glacial aquifer.

Production wells north of Route 25A are screened within the Lloyd, Magothy, upper glacial and (or) North Shore aquifers (fig. 2) and are subjected to particle-tracking analysis. The general locations of these wells are Flower Hill (N2052; fig. 14C), Port Washington (N5209, N9809, N5876, N2030, N1715, N1716, and N8790; fig. 14D), Baxter Estates (N6087, N4867; fig. 14E), and Round Hill/Tibbets Lane (N12981/ N12639, N8246; fig. 14E), Governors Lane (N9446; fig. 14E), Village Club (N4389/ N7159; fig. 14E), and Sands Point Golf Club (N8246; fig. 14E). At the bottom of its screened interval in the Magothy aquifer, Flower Hill production well N2502 captures some deep groundwater originating south of Route 25A, which may flow under the southwest corner of an industrial park (figs. 2 and 14C). At the top of its screened interval in the Magothy aquifer, production well N2502 may also capture some shallow groundwater recharged from points several hundred feet to the south. Port Washington production well N5209 (fig. 14D), screened in the upper glacial aquifer, captures shallow groundwater recharged from points several thousand feet to the west. At the bottom of its screened interval in North Shore aquifer, Port Washington production well N9809 (fig. 14D) captures deep groundwater originating to the south, and flowpaths demonstrate a radial pattern near the well. At the top of the screened interval in the North Shore aquifer, production well N9809 captured groundwater that recently (2011) entered into the North Shore aquifer from the adjacent Magothy and upper glacial aquifers through a buried valley several hundred feet to the west. Radial convergence is also apparent in the shallower flowpaths. Throughout the screened intervals in the upper glacial and Magothy aquifers, Port Washington production wells N5876 and N2030 capture shallow groundwater recharged from the east and southeast. Throughout its screened interval in the Lloyd aquifer, Port Washington production well N8790 (fig. 14D) captures deep groundwater originating from the southeast, including some groundwater that would have migrated upwards from the Lloyd aquifer through a buried valley. This old, deep groundwater is prevented from ultimately being discharged to Manhasset Bay by this well capture. Throughout the screened intervals in the Lloyd aquifer, Port Washington production wells N1715 and N1716 (fig. 14D) capture (1) old deep groundwater originating to the southeast, similar to the groundwater captured by well N8790; (2) old, deep groundwater from the shoreline near the Port Washington Yacht Club; and (3) old deep groundwater from the north and east that was initially moving towards the Baxter Estates during a prior period of heavy pumping of wells, including well N35 prior to its closure from saltwater intrusion. Throughout the screened interval in the upper glacial aquifer, Baxter Estates production well N6087 (fig. 14E) captures shallow groundwater recharged from points several thousand feet to the east. Throughout its screened interval in the North Shore aquifer, Baxter Estates production well N4867 captures old, deep groundwater several thousand feet to the southeast. Throughout screened intervals in the upper glacial and North Shore aquifers, Sands Point production wells N12981, N12639, N4389, and N7159 captured shallow groundwater recharged from points several thousand feet to the east. Throughout the screened intervals in the North Shore aquifer, Sands Point production wells N9446 and N8246 captured deep water-table recharge from points several thousand feet to the north, thereby intercepting groundwater that would have discharged to Long Island Sound.

Forward particle tracking also was conducted with water-table starting points (fig. 15) at selected potential contamination sources identified in the New York State environmental facilities database (http://www.dec.ny.gov/ imsmaps/facilities/viewer.htm, accessed July 1, 2011). All these flowpaths indicate that shallow groundwater flows toward the shorelines with no interception by pumped wells. The possible site-specific investigations described below may be useful for improving the accuracy of particle tracking.

- Forward tracking of particles started at the North Hempstead Landfill indicate shallow flow towards Hempstead Harbor; however, backtracked particles from production well N9809 (fig. 14D) indicate radial convergence of particles into the well and some sourcing from points east of well N9809. A detailed site-specific investigation may be useful in understanding the fate of landfill leachate as it relates to well N9809. VOCs were previously detected in well N9809 (Stumm, 2002).

- Forward tracking of particles started at a group of drycleaners in Port Washington (fig. 15), including NYSDEC environmental facility sites 130081 and 130108 (New York State Department of Environmental Conservation, 2009), indicate shallow flow towards both Hempstead Harbor and Manhasset Bay. However backtracking results indicate that production wells N5209, N4867, and N6087 capture groundwater in the general vicinity of the drycleaner, although a significant thickness of the North Shore confining unit blocks the deep-well groundwater sources from contamination near the drycleaner. A detailed sitespecific investigation may be useful in understanding the fate of possible drycleaner contaminant spills as they relate to wells N5209, N4867, and N6087.

\section{Freshwater/Saltwater Transition Zone Movement}

The basic three-dimensional shape of freshwater/ saltwater transition zone is wedge-like with a toe protruding inland. However, there are many factors affecting its shape, 


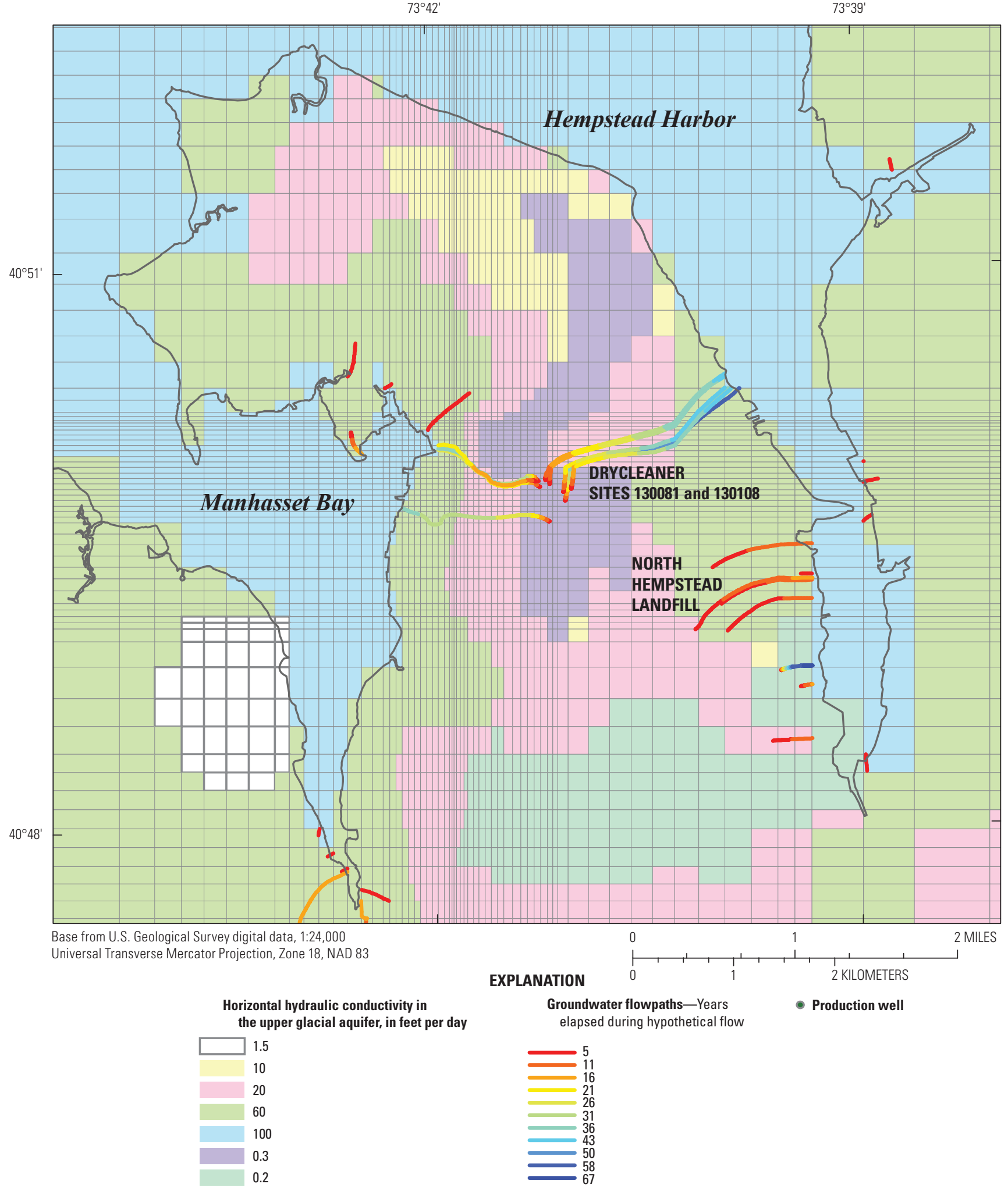

Figure 15. Simulated particle pathlines from forward tracking of particles introduced at the water table during present steady-state conditions, Manhasset Neck, New York. 
including pumping centers, spatial variations in recharge and discharge, the hydrogeologic framework, and density dynamics. Furthermore, the freshwater/saltwater transition zone is in motion. Increased pumpage of groundwater has resulted in saltwater intrusion with associated degradation of the quality of water in production wells. Prevention of the landward movement of the transition zone requires that freshwater is naturally discharged from the aquifer at a rate sufficient to keep the transition zone at a stable location. Model simulations represent the complex interplay of hydrologic stresses that affect the size and shape of the transition zone between saline and fresh groundwater.

The simulated changes in salinity (chloride concentration) in the North Shore and Lloyd aquifers are shown from predevelopment to the present (fig. 12) and during future hypothetical conditions (fig. 16). In the maps, salinity (chloride concentration) contours are shown in the upper model layer of the designated aquifer unit to assess the match with observation wells (shown on figures). During the simulated predevelopment period prior to significant well pumping, there was a sufficient pressure head of fresh groundwater in most onshore areas of Manhasset Neck to support fully freshwater conditions from the water table down to the bedrock. In some areas of the extreme north of Manhasset Neck, the freshwater/saltwater transition zone was located landward of the shoreline because of naturally low water-table elevations in wetland areas, isotropic aquifer conditions at depth, and significant thickness of unconsolidated deposits. Simulated and observed change in salinity over time is also presented (fig. 17) for four wells for which records were available: Baxter Estates past production/observation well N35, Sands Point observation well N12318, Neulist Avenue production well N1715, and Port Washington observation well N12508. Simulated chloride concentrations at well screens are overestimated in comparison to simulated chloride concentration contours at the upper part of the aquifer (figs. 12 and 16); however, at pumping wells, local upconing of the freshwater/saltwater transition zone typically occurs as some denser, more saline water is captured from below. The movement of the bottom model layer of the freshwater/saltwater transition zone is landward near the Neulist Avenue wellfield (N1715), in contrast to the seaward movement of upper model layer contours, and is noted on figure 16.

The simulated freshwater/saltwater transition zone, defined as centered on salinity of 0.45 parts per thousand or $250 \mathrm{mg} / \mathrm{L}$ chloride concentration, gradually moved beyond Sands Point observation well N12318 toward the production well field of N36, N37, and N8313, with the rate of movement recently (2011) slowing. Well N35 at Baxter Estates experienced a sharp rise in salinity (chloride concentration) during the 1940s, followed by an equally sharp drop resulting from a curtailment of pumping. The nearby observation well N12232 exhibited a similar pattern (Stumm and others, 2002). The freshwater/saltwater transition zone moved more rapidly landward at Port Washington (N12508), with the main influence on movement of the transition zone being pumping at the Neulist Avenue (N1715) production well. Saltwater intrusion has not yet been observed at the Neulist Avenue wellfield but may be expected from the graph of salinity (chloride concentration) change at this site (fig. 17) and the observed and simulated reduction in water levels (fig. 11C) caused by the pumping. In figure 17 , salinity decreases at well N12508, while at N1715 salinity increases. This result may seem counterintuitive because N1715 is further inland than N12508. Some of the factors that contribute to this result are the following: Location: While it is strictly true that N1715 is further inland than N12508, there are other direction components that may be considered. Inspection of figure 16 shows that N1715 is over a mile away from N12508 in a direction, upgradient regionally, that is parallel to the coast (perpendicular to the "inland" direction). Due to this separation, in a homogenous isotropic flow system, the pumping stresses in and around N1715 are likely enough to generate a localized movement of the saltwater interface at N1715 but not at N12508. N1715 is a pumping well, whereas N12508 is an observation well. Stress History: A complex of history of pumping on Manhasset Neck is one of the reasons a transient state model was constructed for this project. It takes many years for saltwater interfaces to equilibrate to stress conditions, yet stress conditions are constantly changing. Historical pumping of nearby wells to the north of N12508 contributed to the elevated salinity of N12508, but decreases in pumping of wells to the north and south of N12508 will cause a future salinity decline in N12508. However, N1715 continues to pump (at a lower rate), and salinity will increase there. The amount of salinity increase depends on the rate of pumping; scenario 3 demonstrates a case where salinity increase ceases then begins to decrease due to further pumping decrease. Hydrogeologic Framework: Wells N12508 and N1715 are in different hydrogeologic settings. The Lloyd aquifer is more permeable than the North Shore aquifer, and N1715 is more influenced by regional water-level declines than N12508.

Changes in salinity (fig. 17) at Baxter Estates past production/observation well N35, Sands Point observation well N12318, and Port Washington observation well N12508 were simulated for the following three hypothetical scenarios: (1) no change - continuation of 2011 pumping rates combined with long-term average recharge, (2) drought conditions of 50 percent less recharge for 5 years from 2025 to 2030, and (3) transfer of 50 million gallons per year $(18,300$ cubic feet per day) of pumpage from the Neulist Avenue production well N1715 to the off-peninsula well at Christopher Morley Park (N15310), corresponding to a 52 percent decrease in withdrawals at well N1715. Simulated results for salinity (chloride concentration) from scenarios 2 and 3 were graphed (fig. 17) for the following wells for which records of salinity (chloride concentration) determined from chloride concentrations are available: Baxter Estates past production/observation well N35, Sands Point observation well N12318, and Port Washington observation well N12508. 
The freshwater/saltwater transition zone was relatively unaffected by stresses in all three scenarios at Sands Point observation well N12318. The freshwater/saltwater transition zone was unaffected by stresses in all three scenarios at Baxter Estates past production/observation well N35; however, the freshwater/saltwater transition zone was affected by stresses in all three scenarios at Port Washington observation well N12508. In scenario 1, the freshwater/saltwater transition zone retreated seaward and downward, in part, because of the recent reduction in pumpage from about 60,000 gallons per day during the 2001 summer season ( fig.8) to about 21,500 gallons per day during the 2003 summer season (a summer rate of 26,000 gallons per day is applied in the future no change condition). Recent chloride samples at well N1715 (Italo Vecchio, Port Washington Water District, oral commun., 2011) support simulated saltwater transition zone retreat seaward and (or) downward. In scenario 2 with drought conditions, the freshwater/saltwater transition zone advanced at past production/observation well N35. In scenario 3, the retreat of the saltwater transition zone accelerated as a result of the transfer of pumping from Neulist Avenue (well N1715) to Christopher Morley Park (well N15310). At the Neulist Avenue production well N1715, continuation of the 2011 pumping rates (the "no change" scenario 1) resulted in saltwater intrusion to this well field by the year 2030 (fig. 16), and this rate of intrusion accelerated during the simulated 2015 to 2030 drought conditions. During scenario 3 the transfer of pumpage from Neulist Avenue to Christopher Morley Park caused the freshwater/saltwater transition zone to begin to retreat seaward by the year 2015 .

\section{Model Sensitivity}

Sensitivity analysis of horizontal and vertical hydraulic conductivity, porosity, dispersivity, recharge, sea-level elevation, and extent of the offshore confining unit is discussed in Monti and others (2009) for the SUTRA model and is generally applicable to the SEAWAT model. Sensitivity analysis of the SEAWAT model yielded more dynamic salinity (chloride concentration) results than the SUTRA model. This is likely due to (1) differences in mathematical formulations of solute transport between the two models, (2) changes in model framework, (3) changes in areal extent and spatial and temporal discretization of the SEAWAT model, and (4) differences in calibrated hydraulic parameter values (Raritan confining unit and some upper glacial zones). An "alternative framework conceptualization" with upper glacial sediments running under part of Manhasset Bay, discussed in detail in Monti and others (2009), is adopted as the baseline SEAWAT model. Sensitivity analysis of SEAWAT also yielded less dynamic changes in water levels in areas that were constrained by additional boundary conditions and in the unconfined zone of the SEAWAT model (the SUTRA model area was fully confined).
The SUTRA model generally underpredicted historical measured salinity (chloride concentration) data throughout the entire range of sensitivity runs, whereas the SEAWAT model using the same SUTRA model parameters either overpredicted or underpredicted measured salinity (chloride concentration). Sensitivity analysis revealed that salinity (chloride concentration) changes in the North Shore aquifer were sensitive to changes in horizontal hydraulic conductivity. As the horizontal hydraulic conductivity of the North Shore aquifer was decreased in both the SUTRA and SEAWAT models, changes in salinity (chloride concentration) were dampened; in contrast, as the horizontal hydraulic conductivity of the North Shore aquifer was increased, the changes in salinity (chloride concentration) were exaggerated. As discussed in Monti and others (2009), this behavior is due to the overlying position of Manhasset Bay as the saline water source and the movement of saltwater from west to east. The salinity (chloride concentration) resulting from an increase and decrease in the horizontal and vertical hydraulic conductivities (fixed anisotropy ratio) of the Lloyd and North Shore aquifers of 10 percent at Port Washington observation well N12508 are shown in figure 18.

\section{Model Limitations}

The SEAWAT model is a simplified mathematical representation of the complex natural groundwater-flow system of Manhasset Neck. Although the model provides a relatively good fit between simulated and measured or estimated values, which indicates that the overall simulated groundwater flow and solute transport is reasonable, the model is subject to limitations. In general, owing to model scale and level of detail, the model is most applicable to analysis of groundwater issues at regional scales. Greater local-scale heterogeneity in hydrologic properties, recharge, and discharge may not be adequately represented. Some parameters including porosity, specific yield, specific storage, and dispersivity were invariant spatially; however, spatial variations in these parameters are likely to occur in reality. Lack of representation of spatial variation leads to simplification of particle pathlines and the dynamics of freshwater/saltwater transition zone movement. In figures 12 and 18, salinity (chloride concentration) are shown in the upper model layer of the designated aquifer unit, whereas in the graphs of figure 17, values correspond to the well screen zone layer; therefore, these two illustration types are not closely comparable because of the three-dimensional complexity of the hydrogeologic framework. The accuracy of well-pumpage data is always of concern because some wells are not equipped with flow meters or if so equipped, the meter readings are not consistently recorded. There is concern about the accuracy of estimated flow that returns to the aquifer by way of septic-system drain fields and estimated irrigation returns from small residential properties. There is concern about the scale of the grid. A grid of several hundred 


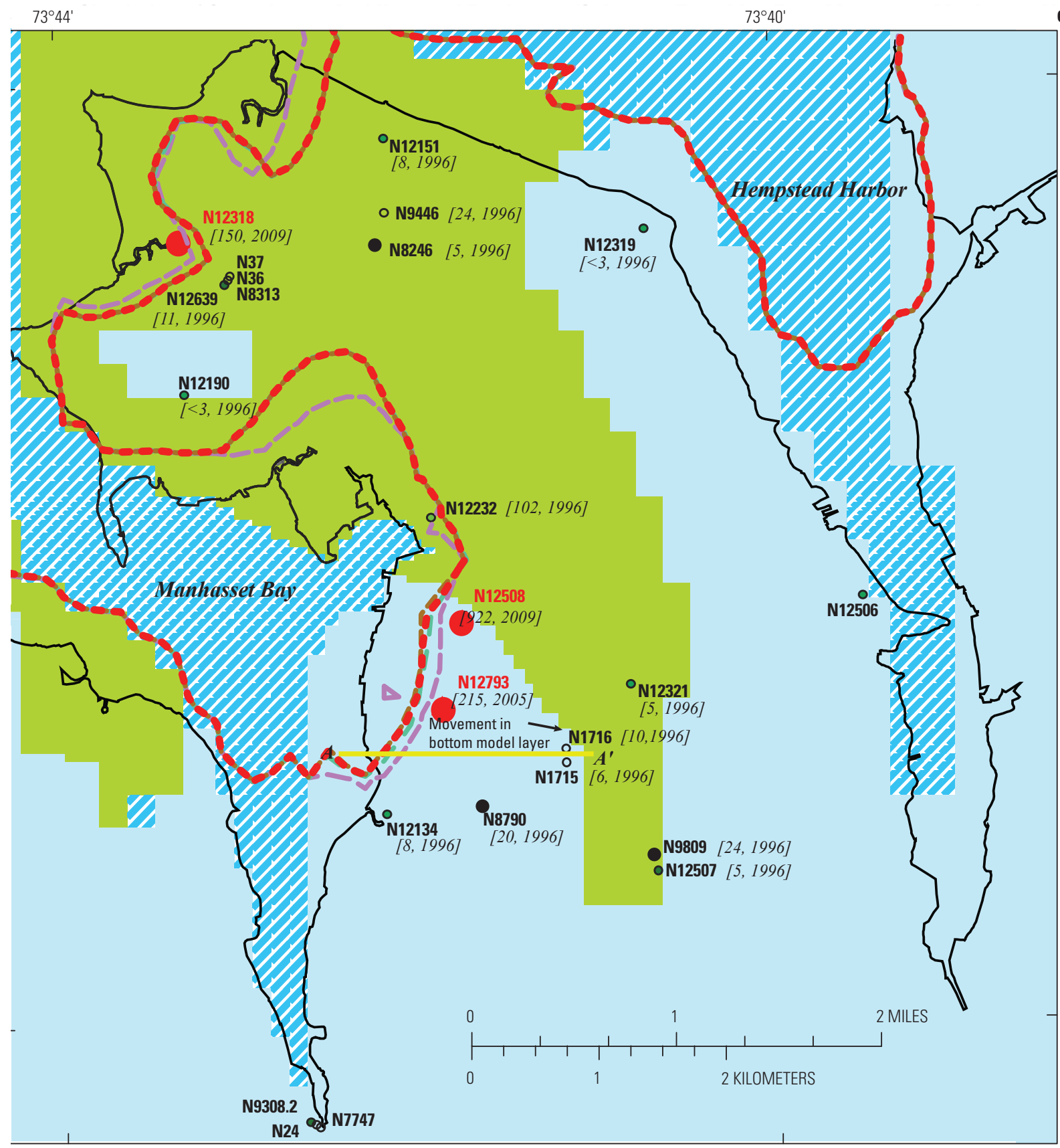

3ase from U.S. Geological Survey digital data, 1:24,000

Iniversal Transverse Mercator Projection, Zone 18, NAD 83
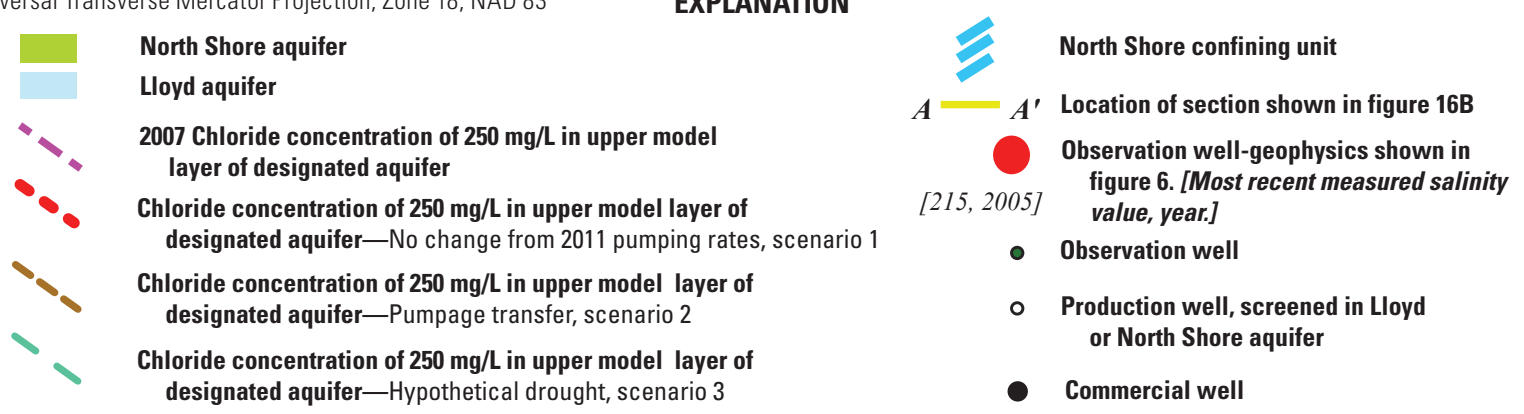

Figure 16A. Lines of the simulated freshwater/saltwater transition zone in the Lloyd and North Shore aquifers for three scenarios, Manhasset Neck, New York, 2007-2030. (mg/L, milligrams per liter) 


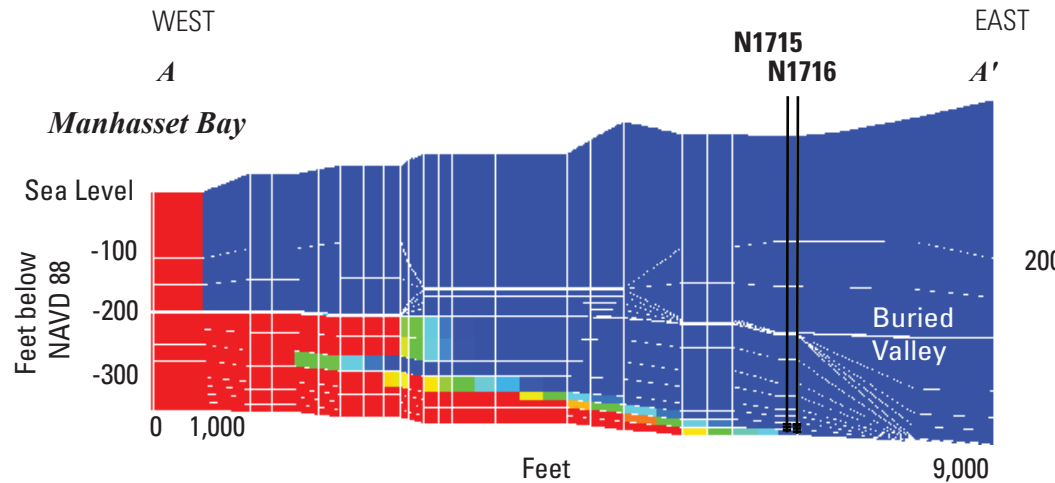

\section{EXPLANATION}

Simulated chloride concentration, milligrams per liter

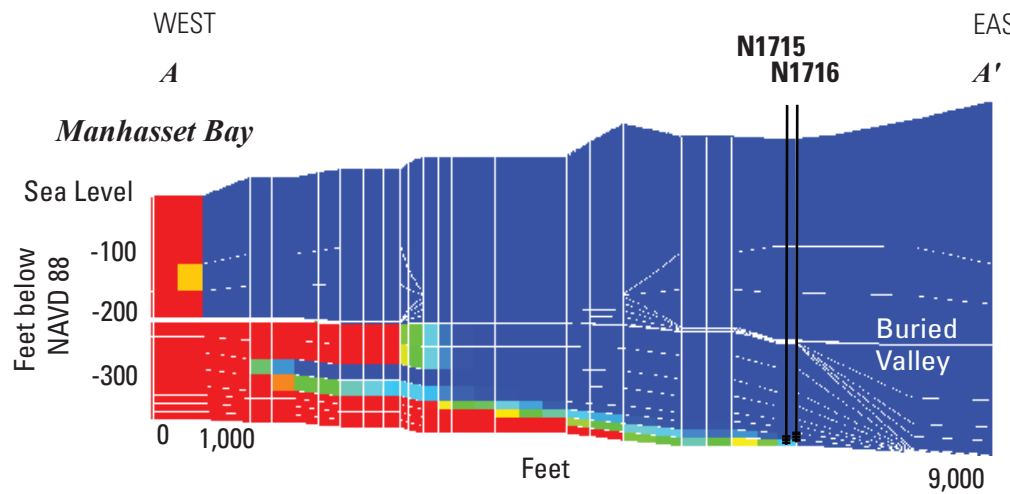

End of

Scenario 1:

2020,

No Change

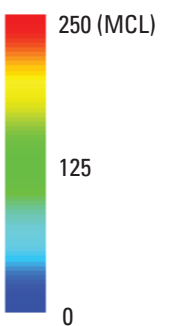

Vertical exaggeration 1:5
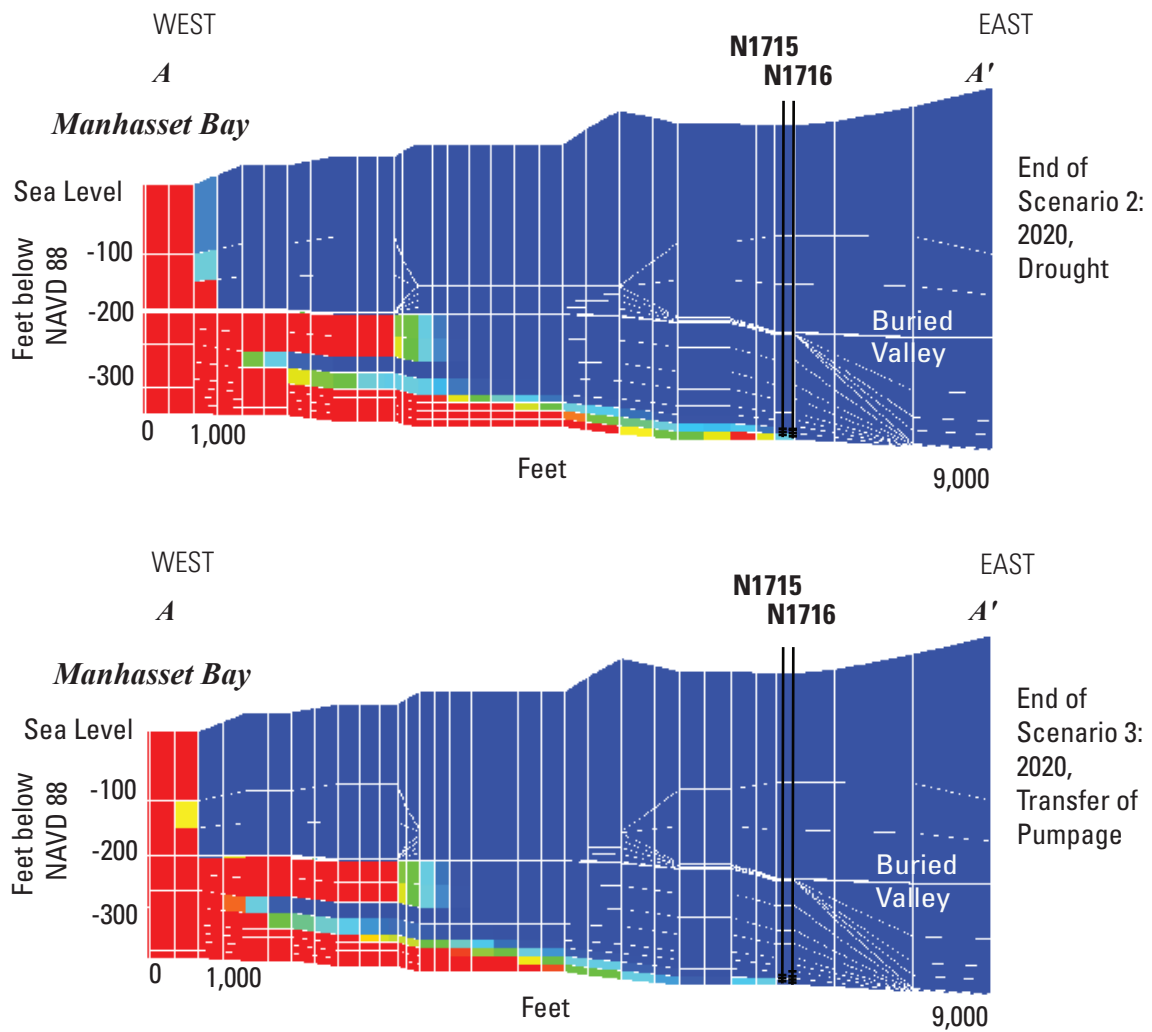

Figure 16B. Lines of the simulated freshwater/saltwater transition zone in the Lloyd and North Shore aquifers for three scenarios, Manhasset Neck, New York, 2007-2030. 

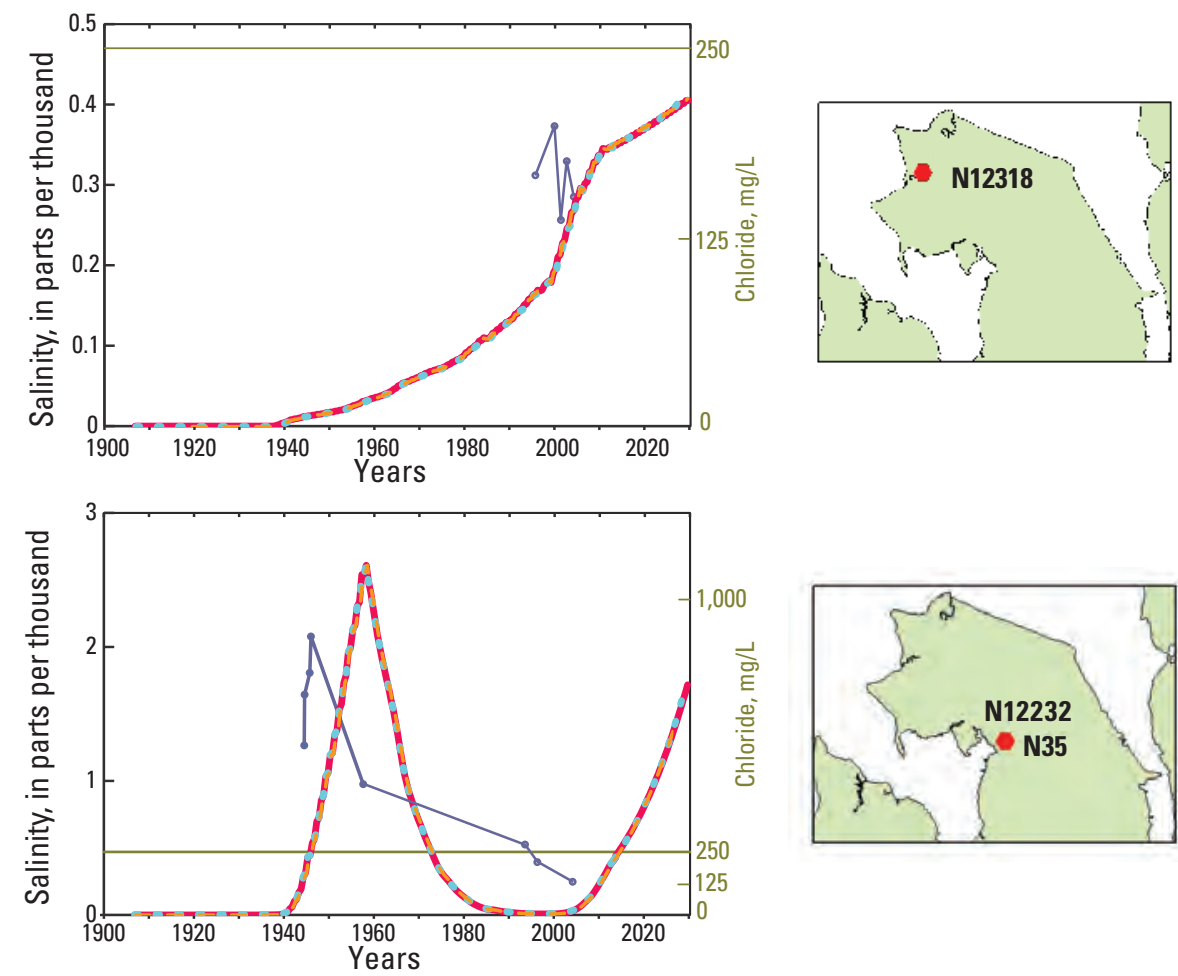

EXPLANATION

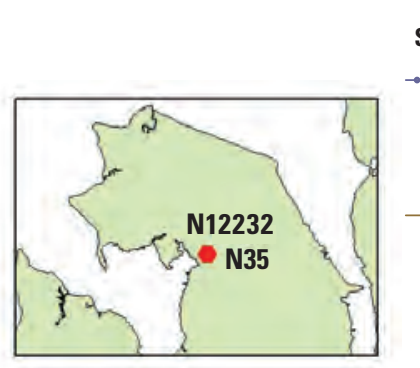

Salinity

- Salinity in groundwater sample

from well, from Stumm and others (2002) and Nassau County Department of Public Works (2005)

- Maximum contaminant level, corresponds to EPA drinking water standard of $250 \mathrm{mg} / \mathrm{L}$ chloride

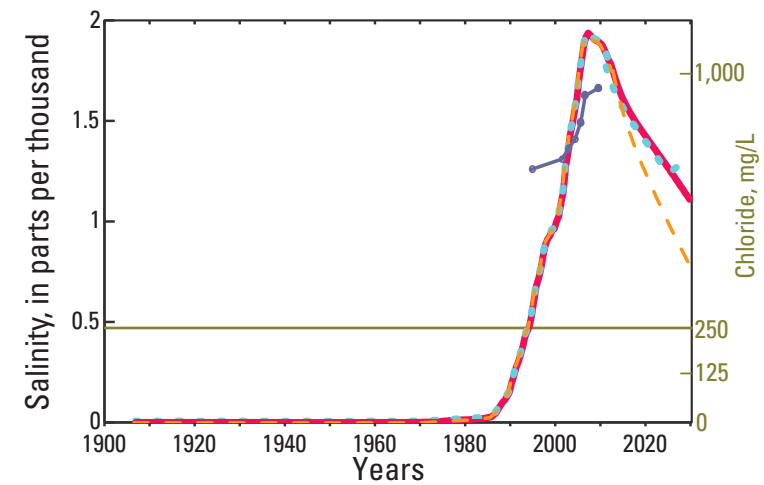

\footnotetext{
Simulated salinity

- No change from 2011 pumping rates, scenario 1

- Simulated salinity for 2025 to 2030 drought conditions, scenario 2

- - Simulated salinity for transfer of pumping off peninsula, scenario 3

- Well for which data are shown in corresponding hydrograph
}
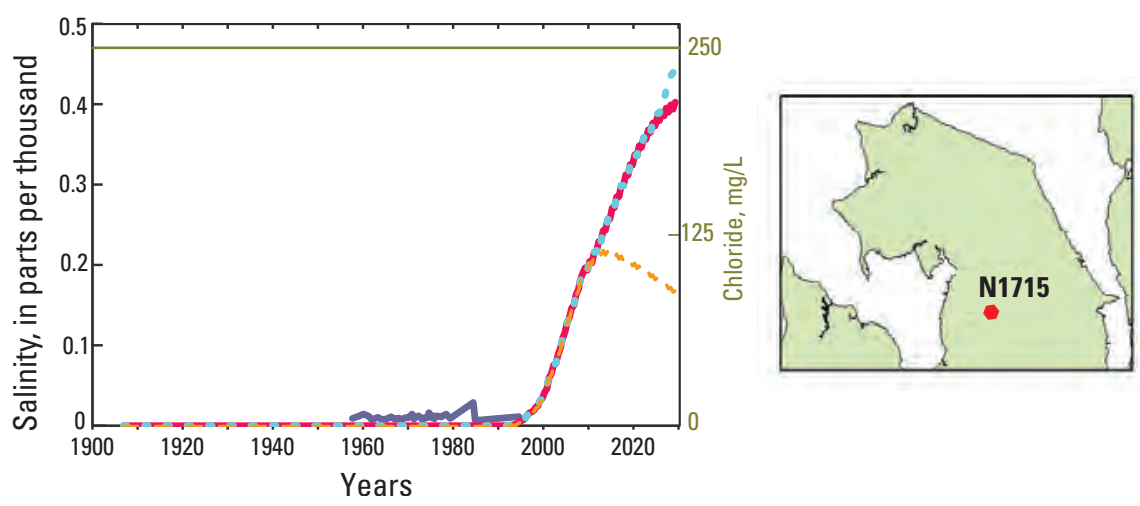

Figure 17. Hydrographs of measured and simulated salinity (chloride concentration) from three scenarios at selected wells, Manhasset Neck, New York, 1920-2030. (EPA, U.S. Environmental Protection Agency; mg/L, milligrams per liter) 


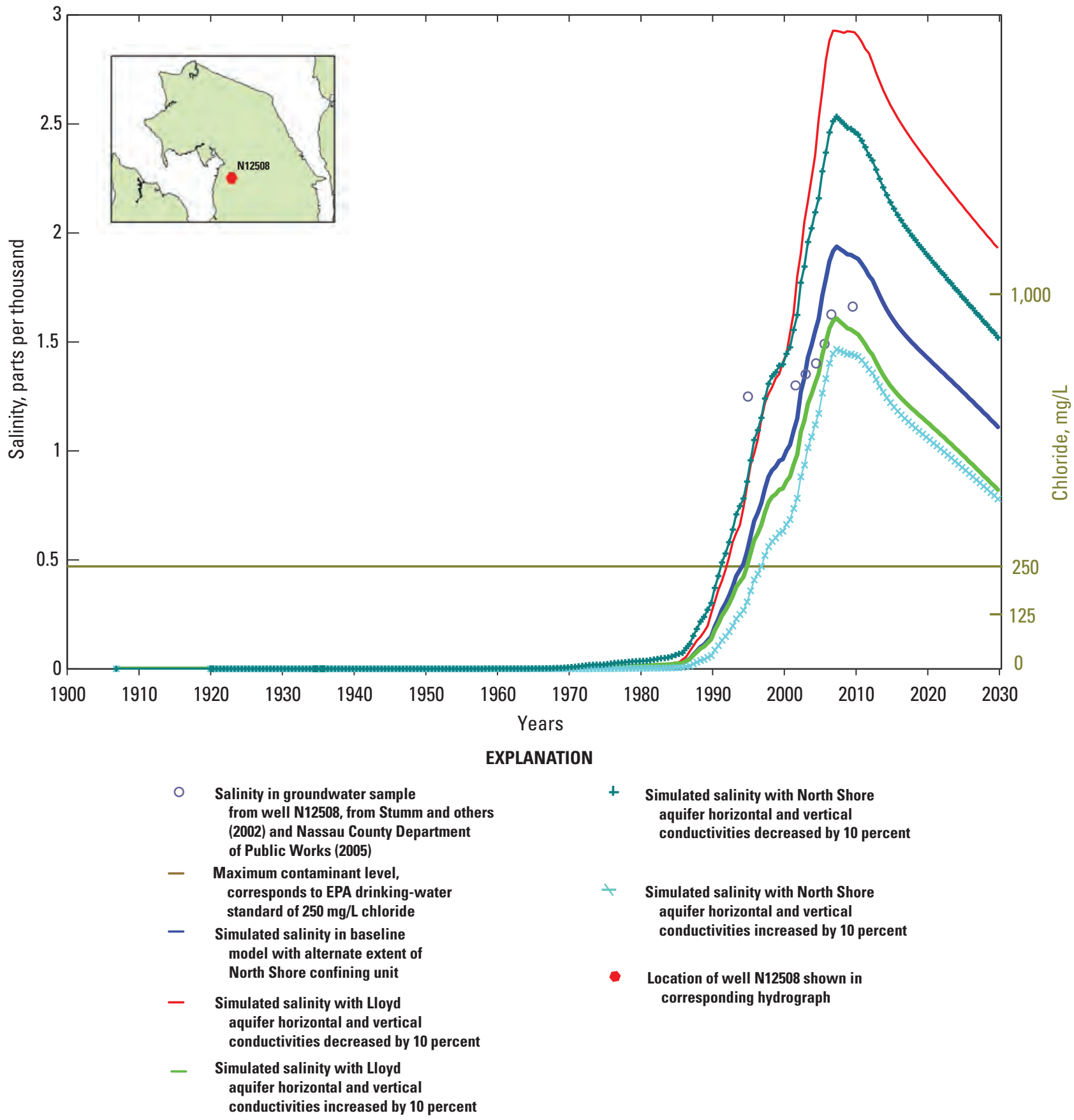

Figure 18. Sensitivity of simulated salinity (chloride concentration) to changes in the vertical and horizontal hydraulic conductivity in the Lloyd and North Shore aquifers at observation well N12508, Manhasset Neck, New York, 1920-2030, using the SEAWAT model. (EPA, U.S. Environmental Protection Agency; mg/L, milligrams per liter) 
feet on a side is applicable to a regional-scale model but probably is not applicable to local-scale models of individual wellfields. Finally, in order to conserve computer resources, a transport subgrid was used to prevent irrelevant simulation of density dynamics in the main part of Long Island that is at least 3 miles from a shoreline (the maximum width of the Manhasset Neck Peninsula is less than 3 miles; fig. 1). This implementation introduced minor numerical oscillations in transport simulation at the boundary of the active/inactive area. These oscillations did not significantly affect simulation of the density dynamics of freshwater/saltwater transition zone movement in the area of interest. In addition, a more computationally intensive model run with the entire flow model grid activated for transport yielded zero oscillations. Model results are included in the archive of files (maintained at the U.S. Geological Survey Water Science Center at Coram, N.Y.) associated with this report. The results of the SEAWAT model demonstrate that any numerical oscillations present in the baseline model were caused by subgrid implementation and did not affect the area of interest.

\section{Summary and Conclusions}

This study constructed a 19 layer, 182-stress-period SEAWAT model of freshwater/saltwater transition zone movement model with unconfined conditions, and a MODPATH model of groundwater flowpaths backtracked from production wells and forward tracked from known sources of contamination. Construction was based on previous U.S. Geological Survey work, including SUTRA modeling, and extended with more recent data and interpretations. Comparison of SUTRA and the SEAWAT models is discussed in the model design and model calibration sections of this report and includes examination of the simulated potential for movement of the freshwater/saltwater transition zone ("Freshwater/Saltwater Transition Zone Movement" and "Model Sensitivity" sections). The following are compared:

(1) water budgets, (2) calibration statistics, and (3) hydraulic conductivity values used in the two models.

In conclusion, the SEAWAT more accurately reproduced measured groundwater levels and salinity (chloride concentration) changes in response to hydrologic stress than the previous SUTRA model. In the future, high capacity pumping of Neulist Avenue wells N1716/N1715 and observation wells N12508 in Port Washington and N12318 in Sands Point may be at risk for continued increasing salinity (chloride concentration). Simulated salinities from three scenarios were graphed for wells for which records of salinities determined from chloride concentrations are available (N12508, N12318, and N35) and for production well N1715 at Neulist Avenue where salinity (chloride concentration) increases have not yet been observed. Regional maps of simulated salinities for the three scenarios are presented. Risks of increasing salinity (chloride concentration) were evident in the results of scenarios 1 , no change-continuation of 2011 pumping rates and 3 transfer of pumping off the peninsula. The pumpage transfer scenario appears to partially mitigate increasing salinity (chloride concentration) risks at the Neulist Avenue wellfield and reverse the direction of freshwater/saltwater transition zone movement. However, the pumpage transfer scenario does not appear to have a significant effect on the increasing salinity (chloride concentration) risk at Sands Point.

In future hypothetical drought conditions, high capacity pumping of Neulist Avenue wells N1716/N1715 and observation wells N12508 in Port Washington and N12318 in Sands Point may be at risk for further continued increasing salinity (chloride concentration). Simulated salinity (chloride concentration) responses to future drought scenarios at these wells were graphed and mapped regionally. Simulated historical and future salinity (chloride concentration) changes at Port Washington observation well N12508 are sensitive to horizontal and vertical hydraulic conductivity values used to represent Lloyd and North Shore aquifers.

Simulation of groundwater flowpaths to pumped wells indicates that, in some cases, the water source to a well is recharge from precipitation falling directly on Manhasset Neck; in other cases, the source is recharge from precipitation falling on areas to the east or south of Manhasset Neck. In some cases, water that is captured by a well is older than the total model simulation time of 90 years, and the model does not indicate the recharge source areas. Groundwater flowpaths associated with all currently (2011) active pumped wells on Manhasset Neck were simulated. Inspection of flowpaths reveals many hydrogeologic features that affect direction and velocity of flow, and the size and shape of source-area delineations. When flowpaths cross hydrogeologic units, changes in hydraulic properties typically result in direction and velocity changes; for example, flowpaths typically travel in a more vertically oriented direction through confining units than through aquifers. Flowpaths associated with Port Washington (N12508) are generally more complex than those of other areas. These flowpaths include many deflection and gradient-reversal effects from changing stresses and the influence of a nearby buried valley that makes a hydraulic connection between the Lloyd and upper glacial aquifers.

Simulation of groundwater flowpaths from the water table at selected potential contamination sources indicates shallow flow toward the shorelines with no interception by pumped wells. However, backtracking results indicate that some wells capture groundwater in the general vicinity of the New York State Department of Environmental Conservation contamination sites. Although blocking confining units are typically present between production wells and contamination sites, further investigation may be useful in better understanding the fate of possible contaminant spills as they relate to production wells. 


\section{Selected References}

Aronson, D.A., and Seaburn, G.E., 1974, Appraisal of operating efficiency recharge basins on Long Island, N.Y., in 1969: U.S. Geological Survey Water-Supply Paper 2001-D, 22 p.

Buxton, H.T., and Smolensky, D.A., 1999, Simulation of the effects of the groundwater flow system of Long Island, New York: U.S. Geological Survey Water-Resources Investigations Report 98-4069, 57 p.

Doherty, J., and Johnston, J.M, 2003, Methodologies for calibration and predictive analysis of a watershed model: Journal of American Water Resources Association, v. 39, no. 2 , p. $251-265$.

Franke, O.L., and Cohen, P., 1972, Regional rates of groundwater movement on Long Island, New York, in Geological Survey Research 1972: U.S. Geological Survey Professional Paper 800-C, p. C271-277.

Franke, O.L., and McClymonds, N.E., 1972, Summary of the hydrologic situation on Long Island, New York, as a guide to water-management alternatives: U.S. Geological Survey Professional Paper 627-F, 59 p.

Freeze and Cherry, 1979, Groundwater: Englewood Cliffs, N.J., Prentice-Hall, 604 p.

Harbaugh, A.W., Banta, E.R., Hill, M.C., and McDonald, M.G., 2000, MODFLOW-2000, the U.S. Geological Survey modular ground-water model-User guide to modularization concepts and the ground-water flow process: U.S. Geological Survey Open-File Report 00-92, 121 p., accessed May 2009 at http://water.usgs.gov/nrp/gwsoftware/ modflow2000/ofr00-92.pdf.

Horton, R., Gornitz, V., and Bowman, M., 2010, New York City panel on climate change 2010 report: Annals of the New York Academy of Sciences, chap. 3.

Jacob, C.E., 1941, Notes on the elasticity of the Lloyd sand on Long Island, New York: American Geophysical Union Transactions, v. 22, part 3, p. 783-787.

Langevin, C.D., Thorne, D.T., Jr., Dausman, A.M., Sukop, M.C., and Guo, W., 2007, SEAWAT version 4-A computer program for simulation of multi-species solute and heat transport: U.S. Geological Survey Techniques and Methods, book 6, chap. A22, 39 p.

Long Island Power Authority, 2004, Population survey 2004, Current population estimates for Nassau and Suffolk Counties and the Rockaway Peninsula: Uniondale, N.Y., Long Island Power Authority, 38 p.
McClymonds, N.E., and Franke, O.L., 1972, Watertransmitting properties of aquifers on Long Island, New York: U.S. Geological Survey Professional Paper 627-E, $24 \mathrm{p}$.

McWorter, D.B., and Sunada, D.K., 1977, Groundwater hydrology and hydraulics: Fort Collins, Colo., Water Resources Publications.

Miller, J.F., and Frederick, R.H., 1969, The precipitation regime of Long Island, N.Y.: U.S. Geological Survey Professional Paper 627-A, 21 p.

Misut, P.E., and Feldman, S.M., 1996, Delineation of areas contributing recharge to wells in central Long Island, New York by particle tracking: U.S. Geological Survey OpenFile Report 95-703, 47 p.

Misut, P.E., and Busciolano, R., 2010, Hydraulic properties of the Magothy and Upper glacial aquifers at Centereach, Suffolk County, New York: U.S. Geological Survey Scientific Investigations Report 2009-5190, VI, 23 p.

Misut, P.E., and Monti, J., Jr., 2009, Estimation of recharge applied to a density-dependent flow model of Manhasset Neck, Long Island, New York, in PEST Conference, 1, November 1-3, 2009, Potomac, Maryland: Bethesda, Md., S.S. Papadopolous Associates, Inc., proceedings.

Misut, P.E., Yulinksy, W., Cohen, D., St. Germain, D., Voss, C.I., and Monti, J. Jr., 2003, Modeling Seawater Intrusion of the Coastal Plain Aquifers of New York City, USA: Second International Conference on Saltwater Intrusion and Coastal Aquifers-Monitoring, Modeling, and Management, Mexico, March 30 to April 2, 2003.

Monti, Jack, Jr., Misut, P.E., and Busciolano, R., 2009, Simulation of variable-density ground-water flow and saltwater intrusion beneath Manhasset Neck, Nassau County, New York, 1905-2005: U.S. Geological Survey Scientific Investigations Report 2008-5166, 69 p.

Monti, Jack, Jr., and Busciolano, R., 2009, Water-table and potentiometric-surface altitudes in the Upper Glacial, Magothy, and Lloyd aquifers beneath Long Island, New York, March-April 2006: U.S. Geological Survey Scientific Investigations Map 3066, 4 sheets.

Nassau County Department of Public Works, 2005, Groundwater monitoring program 2000-2003, accessed 2013, at http://www.nassaucountyny.gov/agencies/DPW/ groundwater.html.

Nassau County Department of Public Works, 2013, Map of Sewage Treatment in Nassau County, accessed 2013, at http://www.nassaucountyny.gov/agencies/DPW/ WasteWater.html. 
National Oceanic and Atmospheric Administration, National Ocean Service, 1998, Bathymetric digital elevation models at 30 meter resolution: Silver Spring, Md., National Oceanic and Atmospheric Administration accessed February 15, 2005, at http://spo.nos.noaa.gov/bathy/.

New York Department of Environmental Conservation, 2009, Munsey Cleaners and Plaza Cleaners sites, site nos. 130081 and 130108, town of North Hempstead, N.Y.: New York Department of Environmental Conservation, Fact Sheet 2 p.

New York Department of Environmental Conservation, 2011, New York state environmental facilities database: New York Department of Environmental Conservation, accessed July 1, 2011, at http://www.dec.ny.gov/imsmaps/facilities/ viewer.htm.

New York State Orthoimagery Program, 2011, $2 \mathrm{ft}$ natural color imagery from digital camera, accessed July 1, 2011, at http://gis.ny.gov/gateway/orthoprogram/ortho_options.htm.

Perlmutter, N.M., and Geraghty, J.J., 1963, Geology and ground-water conditions in southern Nassau and southeastern Queens Counties, Long Island, N.Y.: U.S. Geological Survey Water-Supply Paper 1613-A, 205 p.

Pollock, D.W., 2012 , User's guide for MODPATH, version 6-A particle-tracking model for MODFLOW: U.S. Geological Survey Techniques and Methods 6-A41, 58 p.

Reynolds, R.J., 1982, Base flow of streams on Long Island, New York: U.S. Geological Survey Water-Resources Investigations Report 81-48, 33 p.

Stumm, F., Lange, A.D., and Candela, J.L., 2002, Hydrogeology and extent of saltwater intrusion on Manhasset Neck, Nassau County, New York: U.S. Geological Survey Water-Resources Investigations Report 00-4193, $42 \mathrm{p}$.

Suter, Russell, de Laguna, Wallace, and Perlmutter, N.M., 1949, Mapping of geologic formations and aquifers of Long Island, New York: New York State Water Power and Control Commission Bulletin GW-18, 212 p.
Swarzenski, W.V., 1963, Hydrogeology of northwestern Nassau and northeastern Queens Counties, Long Island, New York: U.S. Geological Survey Water-Supply Paper $1657,90 \mathrm{p}$.

U.S. Geological Survey, 2002, National land cover data set: U.S. Geological Survey, accessed 2006, at ftp://edcftp.cr.usgs.gov/pub/data/landcover/states. [Site has been reorganized; dataset accessed October 22, 2012, at ftp://edcftp.cr.usgs.gov/data/landcover/states/.]

U.S. Geological Survey, 2011, National water information system: U.S. Geological Survey, accessed 2011, at http:// nwis.waterdata.usgs.gov.

Voss, C.I., 1984, SUTRA, a finite element simulation for saturated-unsaturated, fluid-density-dependent ground-water flow with energy transport or chemically reactive singlespecies solute transport: U.S. Geological Survey WaterResources Investigations Report 84-4369, 409 p.

Voss, C.I., Boldt, David, and Shapiro, A.M., 1997, A graphical-user interface for the U.S. Geological Survey's SUTRA code using Argus ONE (for simulation of variabledensity saturated-unsaturated ground-water flow with solute or energy transport): U.S. Geological Survey Open-File Report 97-421, $106 \mathrm{p}$.

Voss, C.I., and Provost, A.M., 2002, SUTRA, A model for saturated-unsaturated variable-density ground-water flow with solute or energy transport: U.S. Geological Survey Water-Resources Investigations Report 02-4231, 250 p.

Zheng, C., and Wang, P.W., 1999, MT3DMS, A modular three-dimensional multi-species transport model for simulation of advection, dispersion and chemical reactions of contaminants in groundwater systems; Documentation and user's guide: Vicksburg, Miss., U.S. Army Engineer Research and Development Center Contract Report SERDP-99-1, $202 \mathrm{p}$. 


\section{Appendix 1}

Table 1-1. List of wells with New York State Department of Environmental Conservation and U.S. Geological Survey identification numbers.

[NYSDEC, New York State Department of Environomental Cpmservation; USGS, U.S. Geological Survey]

\begin{tabular}{|c|c|c|c|}
\hline NYSDEC & USGS & NYSDEC & USGS \\
\hline N10034 & [Production well not in USGS database] & N4867 & [Production well not in USGS database] \\
\hline N10206 & [Production well not in USGS database] & N5156 & 404239073420201 \\
\hline N11279 & 405122073360601 & N5209 & [Production well not in USGS database] \\
\hline N1129 & 404123073394802 & N5528 & 404731073400601 \\
\hline N11396 & 404327073341701 & N5762 & 405129073361501 \\
\hline N11570 & 404326073341801 & N5792 & 405014073373601 \\
\hline N11798 & 405004073353401 & N5876 & [Production well not in USGS database] \\
\hline N1194 & 404659073332601 & N6087 & [Production well not in USGS database] \\
\hline N12134 & 404853073421101 & N6294 & 405001073343205 \\
\hline N12190 & 405048073431401 & N7159 & [Production well not in USGS database] \\
\hline N12232 & 405010073415009 & N7493 & 404237073433701 \\
\hline N12318 & 405121073432101 & N7512 & 404536073410301 \\
\hline N12319 & 405123073404402 & N7551 & [Production well not in USGS database] \\
\hline N12321 & 404925073405401 & N7552 & [Production well not in USGS database] \\
\hline N12506 & 404944073392601 & N7560 & [Production well not in USGS database] \\
\hline N12507 & 404834073403701 & N7747 & [Production well not in USGS database] \\
\hline N12508 & 404943073414701 & N8010 & [Production well not in USGS database] \\
\hline N12639 & [Production well not in USGS database] & N8246 & [Production well not in USGS database] \\
\hline N12973 & 404921073415401 & N8313 & 405106073430601 \\
\hline N12981 & [Production well not in USGS database] & N8564 & [Production well not in USGS database] \\
\hline N1483 & 405019073415302 & N8790 & [Production well not in USGS database] \\
\hline N15310 & [Production well not in USGS database] & N8979 & [Production well not in USGS database] \\
\hline N1615 & 404210073340801 & N9210 & [Production well not in USGS database] \\
\hline N17 & 404437073402301 & N9211 & [Production well not in USGS database] \\
\hline N1715 & 404908073410901 & N9308 & 404735073424101 \\
\hline N1716 & 404911073411101 & N9309 & 404112073421003 \\
\hline N2030 & 404907073410901 & N9334 & [Production well not in USGS database] \\
\hline $\mathrm{N} 24$ & 404735073424218 & N9446 & 405126073421002 \\
\hline N2502 & [Production well not in USGS database] & N9809 & 404838073404202 \\
\hline N2528 & 405101073343401 & Q305 & 404250073453801 \\
\hline N3475 & 404850073344501 & Q3163 & 404225073453302 \\
\hline N35 & 405010073414901 & Q3661 & 404357073462001 \\
\hline N36 & [Production well not in USGS database] & Q470 & 404541073452601 \\
\hline N37 & 405113073430201 & Q577 & 404418073434101 \\
\hline N4389 & 405056073410903 & & \\
\hline
\end{tabular}


Appendix 2. Slice-sequence animations of hydrogeologic units, Manhasset Neck Peninsula, N.Y.

(http://pubs.usgs.gov/sir/2013/5201/video/sir2013-5201_video1.mp4 and http://pubs.usgs.gov/sir/2013/5201/video/sir2013-5201_ video2.mp4)

Video 1:

1. Slices correspond to groundwater model rows.

2. Colors correspond to hydraulic conductivity from 0.001 (blue) to 200 (red) feet per day.

Video 2:

1. Slices correspond to groundwater model columns.

2. Colors correspond to hydraulic conductivity from 0.001 (blue) to 200 (red) feet per day. 
Prepared by the Pembroke Publishing Service Center

For additional information write to:

New York Water Science Center

U.S. Geological Survey

2045 Route 112, Bldg. 4

Coram, NY 11727

Information requests:

(518) 285-5602

or visit our Web site at: http://ny.water.usgs.gov 


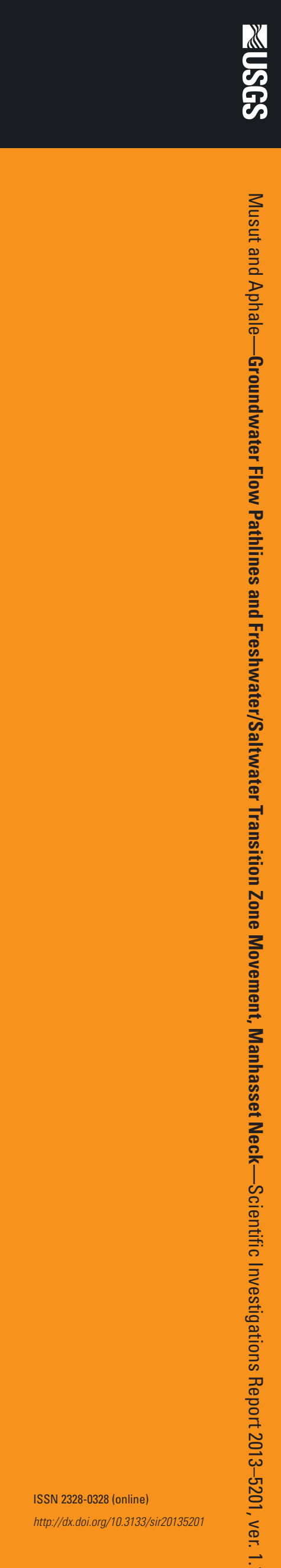

